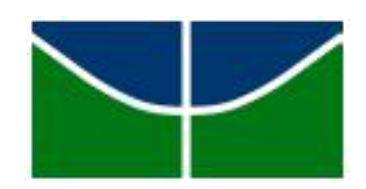

UNIVERSIDADE DE BRASÍLIA - UnB

FACULDADE DE AGRONOMIA E MEDICINA VETERINÁRIA - FAV PROGRAMA DE PÓS-GRADUAÇÃO EM AGRONOMIA

CARACTERIZAÇÃO AGRONÔMICA DE ACESSOS DE CAFÉ CONILON IRRIGADO NO CERRADO DO PLANALTO CENTRAL

MATEUS ROLLEMBERG SANTIN

TESE DE DOUTORADO EM AGRONOMIA

PUBLICAÇÃO: 047D/2016

BRASÍLIA/DF

MAIO DE 2016 


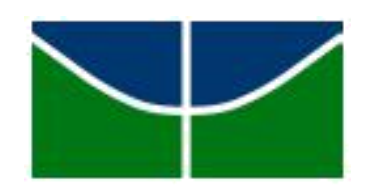

UNIVERSIDADE DE BRASÍLIA - UnB

FACULDADE DE AGRONOMIA E MEDICINA VETERINÁRIA - FAV PROGRAMA DE PÓS-GRADUAÇÃO EM AGRONOMIA

\title{
CARACTERIZAÇÃO AGRONÔMICA DE ACESSOS DE CAFÉ CONILON IRRIGADO NO CERRADO DO PLANALTO CENTRAL
}

\author{
MATEUS ROLLEMBERG SANTIN
}

ORIENTADOR: JOSÉ RICARDO PEIXOTO

COORIENTADOR: RENATO FERNANDO AMABILE

TESE DE DOUTORADO EM AGRONOMIA

PUBLICAÇÃO: 047D/2016

BRASÍLIA/DF

MAIO/2016 


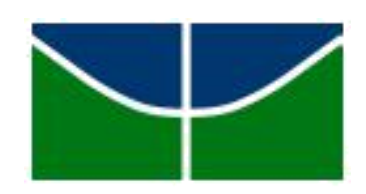

UNIVERSIDADE DE BRASÍLIA - UnB

FACULDADE DE AGRONOMIA E MEDICINA VETERINÁRIA - FAV PROGRAMA DE PÓS-GRADUAÇÃO EM AGRONOMIA

\author{
CARACTERIZAÇÃO AGRONÔMICA DE ACESSOS DE CAFÉ \\ CONILON IRRIGADO NO CERRADO DO PLANALTO CENTRAL
}

\author{
MATEUS ROLLEMBERG SANTIN
}

TESE DE DOUTORADO SUBMETIDA AO PROGRAMA DE PÓSGRADUAÇÃO EM AGRONQMIA, COMO PARTE DOS REQUISITOS NECESSÁRIOS À OBTENÇÃO DO GRAU DE MESTRE/DOUTOR EM AGRONOMIA.

APROVADA POR:

José Ricardo Peixoto (ORIENTADOR)

Professor Doutor/Universidade de Brasília/CPF: 354.356.236-34

E-mail: peixoto@unb.br

Marcelo Fagioli (EXAMINADOR INTERNO)

Professor Doutor/Universidade de Brasília/CPF: 729.409.306-78

E-mail: mfagioli@unb.br

Ricardo Carmona (EXAMINADOR INTERNO)

Professor Doutor/Universidade de Brasília/CPF: 186.492.181-

34 E-mail: rcarmona@unb.br

Edilene Carvalho dos Santos Marchi,

Professora Doutora/Instituto Federal de Brasília/CPF: 000.236.256-27

E-mail: edilene.marchi@ifb.edu.br

Gabriel Ferreira Bartholo (EXAMINADOR EXTERNO)

Pesquisador Doutor/Embrapa Café/CPF: 089.356.236-34

E-mail: chgeral.cafe@embrapa.br

BRASÍLIA, DF, 31 DE MAIO DE 2016 


\section{FICHA CATALOGRÁFICA}

Santin, Mateus Rollemberg.

Caracterização agronômica de acessos de café Conilo $\mathrm{n}$ irrigado no Cerrado

do Planalto Central. / Mateus Rollemberg Santin; Orientação de José Ricardo

Peixoto; Coorientação de Renato Fernando Amabile - Brasília, DF, 2016.

136f.: il.

Tese de Doutorado (D) - Universidade de Brasília/Fa culdade de Agronomia

e Medicina Veterinária, 2016.

1.Coffea canephora. 2. Desempenho agronômico 3. Parâmetros genéticos 4.

Ciclo de maturação 5. Resistência genética.

\section{REFERÊNCIA BIBLIOGRÁFICA}

SANTIN, M. R. Caracterização agronômica de acessos de café Conilo n irrigado no

Cerrado do Planalto Central. Brasília. Faculdade de Agronomia e Medicina

Veterinária, Universidade de Brasília, 2016. 74 f.Tese de Doutorado.

\section{CESSÃO DE DIREITOS}

NOME DO AUTOR: Mateus Rollemberg Santin.

TÍTULO: Caracterização agronômica de acessos de café Conilo n irrigado no Cerrado do Planalto Central.

GRAU: Doutor. $\quad$ ANO: 2016.

É concedida à Universidade de Brasília permissão pa ra reproduzir cópias desta tese de doutorado e para emprestar ou vender tais cópias so mente para propósitos acadêmicos e científicos. Ao autor reservam-se outros direitos de publicação e nenhuma parte desta tese de doutorado pode ser reproduzida sem a autorização por escrito do autor.

Mateus Rollemberg Santin

CPF: 004.956.281-90

Ministério Público do Distrito Federal e Territórios. Praça do Buriti, Eixo

Monumental, s/n - Zona Cívico-Administrativa. Brasília, DF, 700 91-900.

+556133436312/ mateusantin@gmail.com 
"Pouca Ciência torna os homens orgulhosos;

muita Ciência os torna humildes. Assim, as

espigas vazias elevam a cabeça soberba,

enquanto as cheias inclinam-se, humildemente, para a terra."

Leonardo da Vinci.

"Se tenho as mãos macias, eu devo tudo aos meus pais, que 'teve' as mãos calejadas, no tempo que longe vai."

Trio Parada Dura

Aos meus pais, meus irmãos e minha esposa,

DEDICO. 


\section{AGRADECIMENTOS}

Agradeço a Deus, pela oportunidade de viver neste $\mathrm{m}$ undo e presenciar os milagres da Natureza.

Aos meus pais, Marcus e Rosa, pelo exemplo que me deram, pelos ensinamentos que me passam diariamente e ao longo de toda a minha vida, e pelas oportunidades que me proporcionaram com seu suor e abnegação.

Aos meus irmãos, Tiago, Maíra e Lucas, pela convivência e pelo que aprendemos juntos.

À minha mulher, Juliana, minha Branquinha, por esta $\mathrm{r}$ sempre ao meu lado e pelo que estamos construindo juntos.

Ao meu amigo Djan, pelo companheirismo e pelo exemplo de humildade e dedicação às necessidades dos outros.

Aos meus primos e amigos, que sempre me apoiaram e incentivaram.

À Fazenda Mineira, por tudo o que tive a oportunida de de aprender ali, e pelas excelentes lembranças.

Ao meu orientador, Prof. José Ricardo Peixoto, e aomeu coorientador, Renato Fernando Amabile pelos ensinamentos ao longo destes anos de trabalho juntos, e por me apoiarem, na medida do possível, a desenvolver minhas ideias neste trabalho.

À Embrapa Café, nas pessoas dos pesquisadores Dr. A ntônio Fernando Guerra e Dr. Gabriel Ferreira Bartholo, por abrirem as portas do campo experimental para que pudéssemos desenvolver o presente trabalho. Ao pesquisador Dr. Omar Cruz Rocha, pela disponibilidade e disposição em ajudar sempre que foi solicitado.

Ao Juaci Vitória Malaquias, pela grande dedicação e disponibilidade em auxiliar nas análises estatísticas. Sua ajuda foi ssencial. À Professora Michelle Souza Vilela, pelo indispensável auxílio com as análisesestatísticas do Terceiro Capítulo.

Aos colegas de UnB Ricardo Sayd, Felipe Brige, Ellen Grippi e Ana Paula Montalvão, e aos colegas Vinícius Simões e André Al ves de Castro Lopes, pelo auxílio fundamental nas coletas de dados experimentais.

Ao Amilton da Silva Pires, que sempre colocou a si e a sua equipe à disposição para ajudar no que fosse necessário.

Aos membros da banca examinadora, Dra Edilene Marchi, Prof. Ricardo Carmona, Prof. Marcelo Fagioli e Prof. Márcio Pires, pela disponibilidade em avaliar e contribuir para o enriquecimento deste trabalho.

A todos aqueles que de alguma forma contribuíram para a realização deste trabalho. Muito obrigado! 


\section{SUMÁRIO}

SUMÁRIO

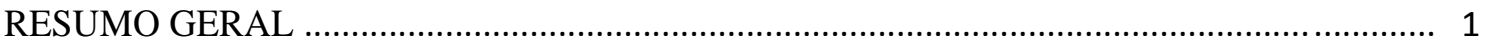

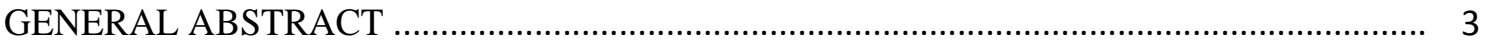

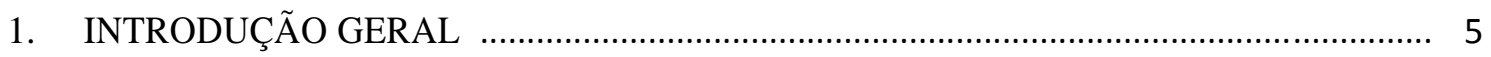

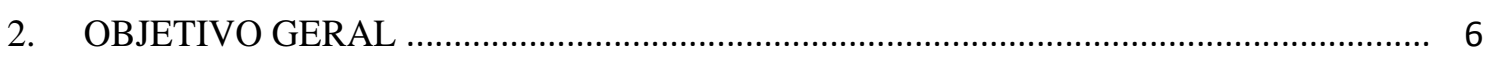

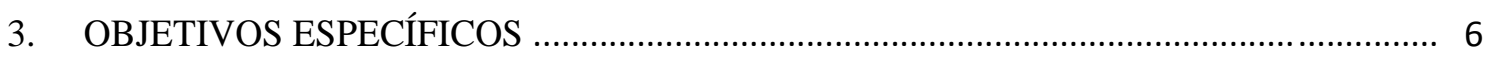

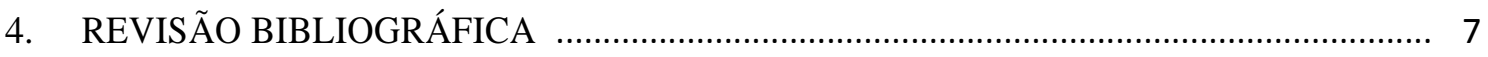

4.1. A espécieCoffea canephora Pierre ex Froehner ........................................................ 7

4.2. Produção brasileira de café ................................................................................... 8

4.3. O Cerrado do Brasil Central e o café do Cerrado...................................................... 9

4.4. Colheita mecanizada de café ................................................................................ 12

4.5. Melhoramento genético emC. canephora ............................................................. 14

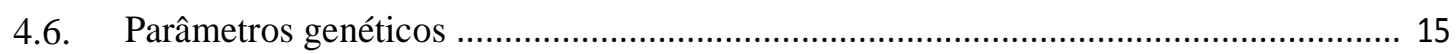

4.7. Ferrugem do cafeeiro (Hemileia vastatrix Berk \& Br.) ........................................... 19

4.8. Cercosporiose do cafeeiro (Cercospora coffeicola Berkeley \& Cooke) ...................... 20

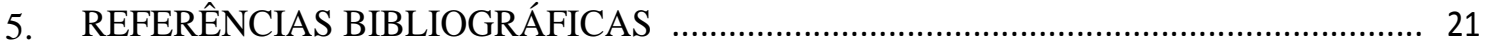

Capítulo 1 - PRODUTIVIDADE, CICLO DE MATURAÇÃO E ESTIMATIVAS DE PARÂMETROS GENÉTICOS DE GENÓTIPOS DE CAFÉ CONILON IRRIGADOS NO

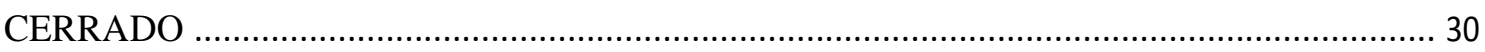

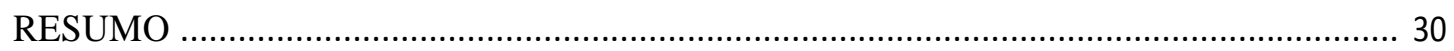

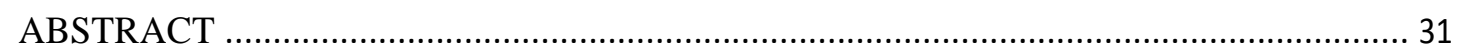

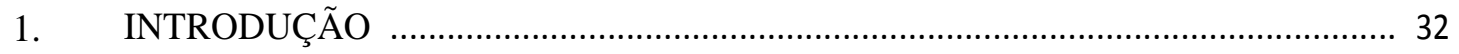

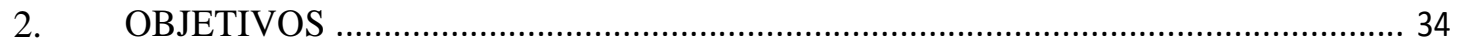

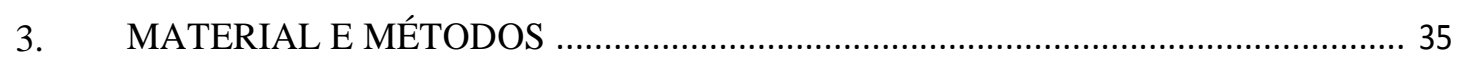

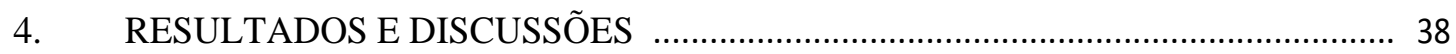

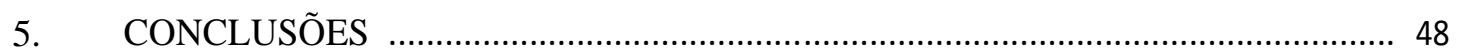

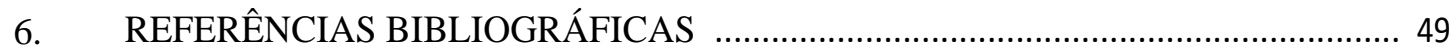




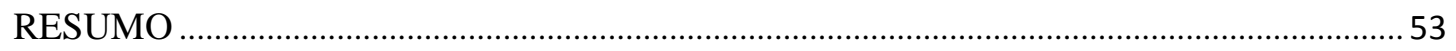

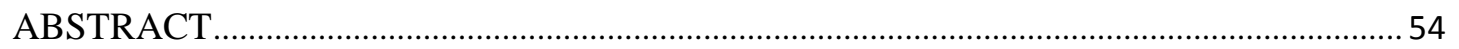

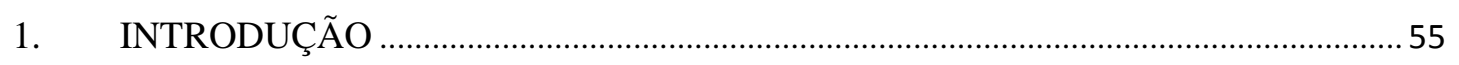

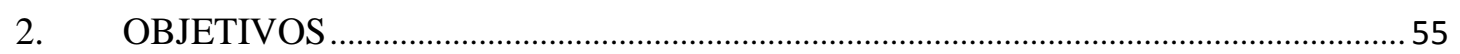

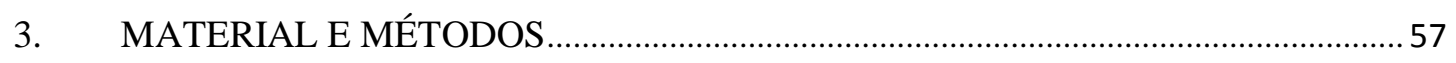

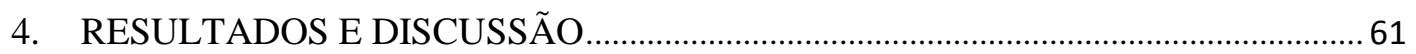

A força de desprendimento dos frutos variou entre o s genótipos e entre os estádios ao longo do ciclo de maturação. Cada grupo de ciclo foi disc utido separadamente.................................. 61

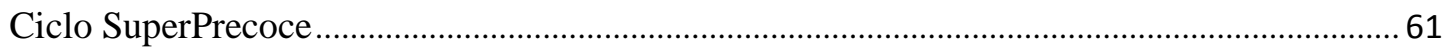

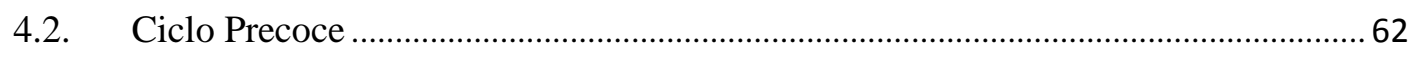

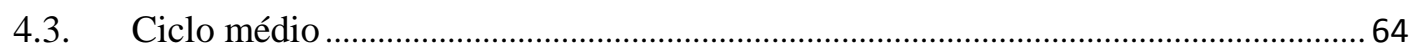

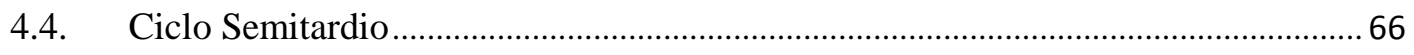

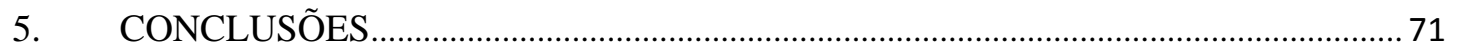

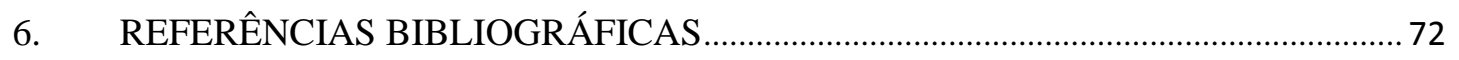

Capítulo 3 - REAÇÃO DE GENÓTIPOS DE CAFÉ CONILON ( Coffea canephora Pierre ex

Froehner) IRRIGADOS NO Cerrado À FERRUGEM E À CERCO SPORIOSE DO CAFEEIRO

74

RESUMO

PALAVRAS-CHAVE: herdabilidade; severidade; resistência genética; seleção fenotípica; tolerância.

REACTION OF CONILON COFFEE (Coffea canephora Pierre ex Froehner) GENOTYPES GROWN IRRIGATED IN Cerrado OF DISTRITO FEDERAL TO COOFEE RUST AND

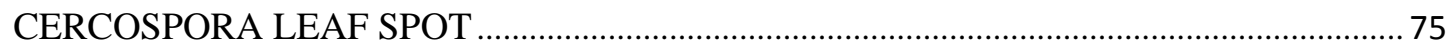

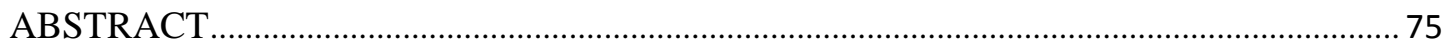

INDEX TERMS: heritability; severity; genetic resistance; phenotipic selection, disease

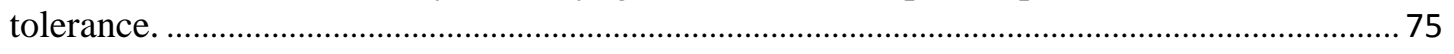

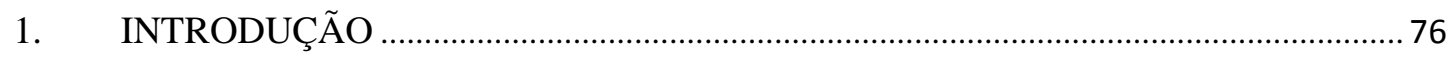

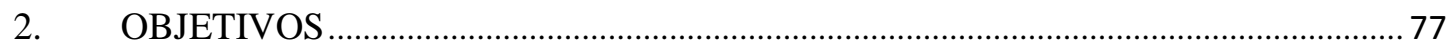




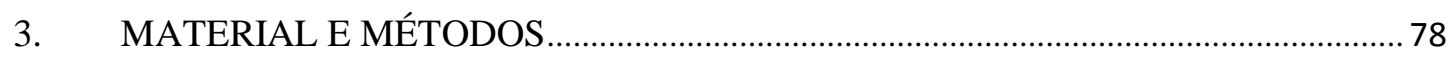

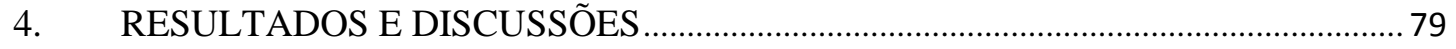

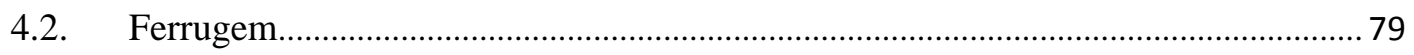

4.3. Cercospora

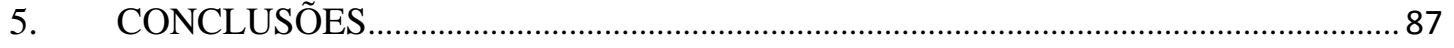

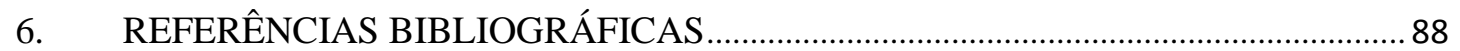




\title{
RESUMO GERAL
}

\author{
Tese de Doutorado \\ Programa e Pós-graduação em Agronomia \\ Universidade de Brasília
}

\section{TÍTULO \\ Caracterização agronômica de acessos de café Conilo $n$ irrigado no Cerrado do Planalto Central}

\author{
Autor: Mateus Rollemberg Santin \\ Orientador: José Ricardo Peixoto \\ Local e data: Brasília, 30 de junho de 2016
}

O Cerrado brasileiro despontou nos últimos anos como uma região bastante propícia à cultura do café, com grandes áreas e alto investimento em tecnologia. O café Conilon, tradicionalmente limitado às regiões de baixa altit ude, apresenta rusticidade e elevada produtividade, com grande potencial para produção e m maior escala nesse bioma. Para tanto, são necessários estudos que avaliem a possibilidade de adaptação desta espécie às condições edafoclimáticas e ao sistema de manejo utilizado na região. O objetivo deste trabalho foi avaliar o desempenho agronômico de gen ótipos de café Conilon, oriundos de cruzamentos em campo isolado da cultivar Robusta Tropical, no Cerrado do Distrito Federal, avaliando sua produtividade, a força de de sprendimento de seus frutos ao longo do ciclo de maturação e sua resistência a duas das principais doenças que afetam o cafeeiro (ferrugem e cercosporiose), num experimento sem repetição no campo, com um representante de cada genótipo, com espaçamento de 3,5 m entre linhas, 1,0 m entre plantas e irrigação por aspersão convencional, real izada por pivô central, e com o uso da tecnologia do estresse hídrico para a uniformização da florada. Para a produtividade, foram usados os dados de produção de três safras consecutivas, e foram classificados os materiais com produção mínima de sete litros por pl anta nos três anos, com coeficiente de variação de produção menor que $25 \%$. Foi realizad a a análise de repetibilidade para estimativa de parâmetros genéticos destes materiais, com o uso do software Selegen. Os resultados obtidos demonstram que existe variabilidade na população estudada para 
produtividade, e os valores de repetibilidade obtidos favorecem a seleção de genótipos superiores para plantio na região, com base nos fen ótipos avaliados. A avaliação da força de desprendimento dos frutos foi realizada ao longo de cinco estádios do ciclo de maturação, a saber: verde, verde cana, cereja, pass a e coco. Seis frutos de cada lado da linha de cultivo eram coletados, e a força de seu d esprendimento foi medida com o auxílio de um dinamômetro da marca Instrutherm®, mo delo DD 300. Com os valores médios para cada estádio foi projetada a curva de egressão não linear da força de desprendimento dos frutos para cada grupo de maturação (superprecoce, precoce, médio e semitardio), com o uso do software estatístico R. Os resultados demonstram que existe variação, para esta característica, entre genótipos e ao longo do ciclo de maturação. O estádio de passa mostrou uma tendência a ser o maisadequado para a colheita mecanizada do café Conilon, por exigir menor força para se desprender dos ramos. A avaliação da reação dos genótipos às doenças foi re alizada em seis épocas, com intervalos médios de 37 dias, com base em escalas diagramáticas desenvolvidas para cada doença, por meio de notas, cujas médias em cada época foram usadas, no software SISVAR, para a análise de variância, e pelo software Genes, para estimativa de parâmetros genéticos. Os resultados obtidos demonstram que existe variabilidade dentro da população para reação a estas doenças, com boa q uantidade de materiais resistentes, alguns materiais moderadamente resistentes e um material tolerante às duas doenças. A estimativa de parâmetros genéticos para a resistência a essas doenças resultou em uma situação mais favorável à seleção fenotípica para f errugem, e pouco menos favorável para cercosporiose do cafeeiro.

Palavras-chave: seleção fenotípica; parâmetros genéticos; repetibil idade; ciclo de maturação; resistência genética. 


\title{
GENERAL ABSTRACT
}

Doctorate Thesis

\author{
Post-graduate Program in Agronomy \\ University of Brasilia
}

\section{TITLE}

\section{Agronomic description of Conilon cofee (Coffea canephora Pierre ex Froehner) accesses grown irrigated in Cerrado of Central Highlands}

\author{
Author: Mateus Rollemberg Santin \\ Adviser: José Ricardo Peixoto \\ Place and date: Brasilia, june 23, 2016
}

The Brazilian Cerrado emerged in recent years as a very favorable region to the coffee culture, with large areas and high investment in technology. Conilon coffee, traditionally limited to low-lying regions, presents hardiness and high productivity, with great potential for larger scale production in this biome. Therefore, studies are needed to assess the possibility of adaptation of this species to environmental conditions and the management system used in the region. The aim of this study was to evaluate the agronomic performance of Conilon coffee genotypes derived from crosses in isolated field of the cultivar Robusta Tropical, in the Cerrado of Distrito Federal, evaluating their productivity, the detachment force of its fruit throughout the ripening cycle and its resistance to two of the major diseases that affect coffee (coffee rust and cercospora leaf spot) in an experiment without repetition in the field, with one individual of each genotype, with spacing of $3.5 \mathrm{~m}$ between rows, 1.0 $\mathrm{m}$ between plants and sprinkler irrigation held by central pivot, and the use of water stress technology to standardize the flowering. For productivity, were used the production data of three consecutive harvests, and were classified materials with minimum production of seven liters per plant in three years with production coefficient of variation lower then $25 \%$. repeatability analysis was performed to estimate genetic parameters of these materials with the use of the software Selegen.The results show that there is variability in the population studied for productivity, and repeatability obtained values favor the selection of superior genotypes for cultivation in the region, based on their phenotypes. The evaluation of the fruit detachment strength was performed over five stages of maturation 
cycle, namely, green, greencane, cherry, pass and dry. Were collectec six fruits of each side of the crop row, and the force of its detachment was measured with the aid of dynamometer Instrutherm ${ }^{\circledR}$ DD 300 . With the average values for each stage were designed the non-linear regression curve of fruit detachment force for each maturity group (super-precoucious, precoucious, medium and medium late), using the statistical software R. The results demonstrate that there is variation for this trait among genotypes and over maturation cycle. The pass stage showed a tendency to be the most appropriate for Conilon coffee mechanized harvesting by requiring less force to break off the branches. The evaluation of the genotypes reaction to disease was performed six times with intervals of 37 days, by notes based on diagrammatic scales developed for each disease, which means of each epoch were used in SISVAR software, for analysis of variance, and in Genes software to estimate genetic parameters. The results obtained show that there is variability within the population for reaction to these diseases, with good amount of resistant materials, some moderately resistant materials and one tolerant genotype to the bouth diseases. The of genetic parameters' estimation for resistance to these diseases resulted in a more favorable situation for the phenotypic selection for coffee rust, and slightly less favorable for the coffee cercospora leaf spot.

Index terms: phenotipic selection; genetic parameters; repeatability; maturation cicle; genetic resistance; 


\section{INTRODUÇÃO GERAL}

O gêneroCoffea, pertencente à família Rubiaceae, possui mais de 100 espécies, dentre as quais se destacam $C$. arabica e $C$. canephora por seu uso comercial. A produção brasileira de café, no ano de 2015, superou os 43 milhões de sacas beneficiadas, sendo $74 \%$ de café arábica e $26 \%$ de café Conilon, e ocupou $23 \%$ da área plantada com a cultura, de um total de quase 2 milhões de hectares.

O café conilon está presente no Brasil especialment nos estados de Espírito Santo, Rondônia e Bahia, onde o período de estiagem é mais curto e as temperaturas de inverno maiores em relação ao Cerrado do Brasil Cen tral, onde a altitude é mais elevada, proporcionando menores temperaturas noturnas no inverno. Ao mesmo tempo, a espécie apresenta ampla variabilidade genética, ossibilitandop a seleção de materiais adaptados a diferentes condições do ambiente de cul tivo.

A produção de café no Cerrado do Brasil Central vem crescendo nos últimos anos, com grande participação do Cerrado mineiro e goiano e do Cerrado baiano, com a cafeicultura empresarial. Surge, então, a possibili dade de aumento da participação do café Conilon nos cultivos realizados nestas regiões. Este aumento, porém, passa necessariamente pela seleção de materiais adaptados às condições ambientais e ao sistema de cultivo destas regiões.

O sistema de produção de café no Cerrado do Brasil Central se caracteriza pelo alto investimento em tecnologia, tanto no que diz respeito à irrigação e mecanização das operações quanto ao manejo nutricional e fitossanit ário das lavouras. A mecanização das atividades da lavoura é uma tendência na agricultura moderna, e com o café não é diferente. Porém, por propriedades inerentes à cultura, a mecanização da colheita do café é um desafio que vem sendo superado nos últimos anos. Devido à sua arquitetura e fisiologia, e também às características das regiões tradicionais de cultivo, em $C$. canephora a mecanização total da colheita ainda não é realiz ada em lavouras comerciais.

Quando se consideram as várias doenças que afetam o cafeeiro, a ferrugem (Hemileia vastatrix Berkeley \& Broome) e a cercosporiose (Cercospora coffeicola Berk. \& Cooke Berkeley \& Cooke) estão entre as mais importantes. O método de controle mais usado atualmente para ambas é o químico. A seleção de materiais resistentes ou tolerantes a estas e outras doenças reduz os custos de produção e 
possibilita melhor qualidade do produto colhido, reduzindo o impacto ambiental do cultivo e protegendo o trabalhador rural.

\section{OBJETIVO GERAL}

Caracterizar fenotipicamente uma população de C. canephora com relação ao desempenho agronômico, ao ciclo de maturação, à for ça de desprendimento dos frutos e à reação às doenças ferrugem ( $H$. vastatrix Berk \& Br.) e cercosporiose (C. coffeicola Berk. \& Cooke), visando explorar a variabilidade existente e permitir o desenvolvimento de variedades adaptadas a diferentes condições edafoclimáticas sob irrigação no Cerrado do Distrito Federal.

\section{OBJETIVOS ESPECÍFICOS}

- Caracterizar a variabilidade fenotípica de uma população de C. canephora irrigada no Cerrado do Distrito Federal com relação ao seu desempenho agronômico.

- Caracterizar a variabilidade fenotípica de uma população de C. canephora irrigada no Cerrado do Distrito Federal com relação ao ciclo de maturação dos frutos.

- Caracterizar a variabilidade fenotípica de uma população de C. canephora irrigada no Cerrado do Distrito Federal com relação à força de desprendimento dos frutos.

- Caracterizar a variabilidade fenotípica de uma população de C. canephora irrigada no Cerrado do Distrito Federal com relação à severidade dos ataques da ferrugem (H. vastatrix Berk \& Br.) e da cercosporiose do cafeeiro (C. coffeicola Berk. \& Cooke). 


\section{REVISÃO BIBLIOGRÁFICA}

\subsection{A espécieCoffea canephora Pierre ex Froehner}

O gêneroCoffea, pertencente à família Rubiaceae, possui mais de 100 espécies, dentre as quais se destacam C. arabica e C. canephora (Davis et al., 2006), por seu uso comercial.

A espécieC. canephora é rústica, tolerante a doenças e adaptada à ampla faixa de condições edafoclimáticas tropicais, de baixas altitudes e temperaturas do ar elevadas. É alógama, diplóide, com 2n=22 cromossomo s (Carvalho et al.,1991, apud Ferrão, 2004). Diferentemente de C. arabica, que é tetraplóide com 2 n=44 cromossomos, autofértil, autocompatível, C. canephora é auto-incompatível, multiplicando-se na natureza exclusivamente por fecundação cruzada. É formada por populações com indivíduos altamente heterozigotos q ue expressam grande variabilidade genética (Conagin e Mendes, 1961; Berthaud, 1980, apud Ferrão, 2004).

De acordo com Chevalier, (1929; 1944, apud Ferrão, 2004), C. canephora inclui diversas variedades, dentre elas Kouillou, Robusta, Sankutu, Bakaba, Uganda, Maclaud, Laurentti, Niaculi e Oka, e vem crescendo de forma espontânea na África tropical em áreas de grande calor e alta umidade, me altitudes que vão desde o nível do mar, no Congo, até altitudes de 1.300m em Guiné, Costa do Marfim, Angola e Uganda. O Conilon, segundo Charrier e Berthaud (1988, apud Ferrão, 2004), se enquadra como uma variedade de hábito de crescimento arbustivo, omc caules ramificados, folhas alongadas, florescimento precoce e tolerante ao déficit hídrico.

Estudos de diversidade genética conduzidos por Berthaud (1986) identificaram dois grupos distintos dentro da espécie, com origens geográficas diferentes: o Guineano e o Congolense. Os cafeeiros designados Conilon são pertencentes ao grupo Guineano e os da Robusta, do congolense. Híbridos e clones altamente produtivos já foram obtidos através de cruzamentos entre materiais dos dois grupos (Ferrão, 2004).

No Brasil, C. canephora é popularmente conhecida como café Robusta ou Conilon, pela maior parte das lavouras da espécie pertencerem a esta variedade. O café conilon se originou da variedade Kouillou, pertencente ao grupo Guineano (Bragança et al., 2001), e apresenta grande variabilidade quanto a diversos fatores como porte, tamanho de sementes e coloração de frutos (Fazuoli, 1986).

Os primeiros cultivos e trabalhos de pesquisa em C. canephora se deram em Java em 1900, mesma época dos primeiros cultivos comerciais. Tudo isto em função da 
grande incidência de ferrugem Hemileia( vastatrix Berk \& Br.) em lavouras de $C$. arabica no sul e leste de Ásia, pela maior resistência de C. canephora a doenças (Ferrão, 2004, citando diversos autores) .

A espécie C. canephora apresenta autoincompatibilidade, a qual, de acordo com Ferrão et al. (2007), diversos autores demonstraram ser do tipo gametofítica, controlada por um único gene $S$, possuidor de uma série de 3 alelos $S_{1}, S_{2}$ e $S_{3}$ alelos. Este mecanismo impede a autofecundação e cruzamento s entre indivíduos com os mesmos alelos de incompatibilidade. Assim, embora seja um obstáculo para determinados processos de produção e melhoramento, a autoincompatibilidade proporciona grande variabilidade genética, fator que pode ser explorado em programas de melhoramento genético.

\subsection{Produção brasileira de café}

O Brasil é o maior produtor mundial de café, responsável por mais de $30 \%$ da produção do grão em 2015, seguido por Vietnã (19,2\% ) e Colômbia $(9,4 \%)$. A cultura ocupava, na safra 2015, área superior a 1,9 milhões de hectares, 23\% destes cultivados com o café Conilon e o restante com Arábica. A produção nacional, considerando-se as duas espécies, ultrapassou os 43,2 milhões de sacas beneficiadas, com o Conilon sendo responsável por quase 11,2 milhões $(25,9 \%)$ deste total. Os estados brasileiros com maior participação na produção de café Conilon na s afra 2015, em milhões de sacas, foram Espírito Santo (7,7), Rondônia $(1,7)$ e Bahia, na região do Atlântico $(1,2)$. Somadas, estas regiões ultrapassam $94 \%$ da produção brasileira de café Conilon. Apesar da superioridade em produção total, o estado do ES teve queda na produtividade de

2015 (27 sc.ha $\left.{ }^{-1}\right)$ em relação a 2014 (35 sc.ha ${ }^{-1}$ ), especialmente devido à falta de chuvas. No último ano, a produtividade da região baiana conhecida como Atlântico atingiu as 34 sacas por hectare, enquanto a média do estado de Rondônia ficou em 20 sc.ha ${ }^{-1}$ (CONAB, 2015). Ainda com relação à produtividade, o café Conilon normalmente supera o Arábica, e em 2015 a diferença ficou em três sacas por hectare (25 contra 22), devido ao grande impacto do estado do ES sobre a média nacional (cerca de 70\%) e ao baixo desempenho da produção deste estado naquele a no.

A produção de café arábica no Cerrado em 2015, de acordo com a CONAB, ficou em 4,2 milhões de sacas (MG), 337 mil sacas ( BA) e 226 mil sacas (GO), com produtividades médias de 24,8, 36,6 e 37 sc.ha ${ }^{-1}$, respectivamente. Comparada à do ano 
anterior, a produtividade reduziu nas três regiões, mais drasticamente no Cerrado mineiro (25\%), devido a problemas climáticos. Nas outras regiões, a redução foi menor que 5\%, muito devido a 2015 ter sido ano de baixa produção. A questão que se destaca aqui é que a média de produtividade do café arábican região do Cerrado é bastante elevada, especialmente pelo alto investimento em tecnologia pelos produtores, com mecanização e irrigação. A união destes fatores ao cultivo de uma espécie naturalmente mais produtiva, como o Conilon, pode ser uma excelente opção (Conab, 2015).

\subsection{O Cerrado do Brasil Central e o café do Cerrado}

O Cerrado é o segundo maior bioma brasileiro, superado apenas pela Amazônia. Ocupa 21\% do território nacional e é cons iderado por Borlaug (2002) a última fronteira agrícolas do planeta (Klink \& Machado, 2005). O clima da região é bem estacional, com uma estação seca, que dura de a bril a setembro, e outra chuvosa, estendida de outubro a março. As médias anuais de precipitação ficam em torno de 1500 $\mathrm{mm}$ e as temperaturas médias variam de 22 a $27^{\circ} \mathrm{C}$ (Klink \& Machado, 2005).

O Cerrado tem se mostrado bastante propício à cultu ra do café, especialmente quando utilizadas tecnologias como irrigação e trat os culturais mecanizados (Fernandes et al., 2012). O café Conilon ou Robusta é cultivado predominantemente em regiões de clima distinto do encontrado no Cerrado do Brasil Central, onde a cafeicultura, com cultivo do café arábica, vem crescendo continuament. As principais diferenças são a maior extensão do período de estiagem e as menores temperaturas do ar durante o inverno no Cerrado do Brasil Central, estas últimas proporcionadas pela maior altitude da região. A grande limitação do café Conilon no Ce rrado está associada às baixas temperaturas nas áreas de maior altitude (Fernandeset al., 2012). Porém, devido à grande diversidade genética existente nesta espécie(Fonseca et al., 2006), a qual pode apresentar diferentes mecanismos de tolerância às b aixas temperaturas (Partelli et al., 2011), é possível inferir que pode ser feita seleçã o de materiais adaptados ao cultivo na região central do Brasil.

Barros et al. (1997) relataram que baixas temperaturas limitam a distribuição geográfica do cultivo de café, com severos efeitosnegativos no crescimento das plantas quando as temperaturas mensais médias ficam abaixo dos $15{ }^{\circ} \mathrm{C}$. Ramalho e colaboradores (2003), citando diversos autores, relacionam as baixas temperaturas como um dos principais fatores limitantes do metabolismo das plantas e frequentemente 
relacionado às baixas produtividades, relataram afe tação nas taxas fotossintéticas de cafeeiros arábica em temperaturas abaixo de $18{ }^{\circ} \mathrm{C}$. Para eles, em espécies sensíveis ao frio, como as tropicais e subtropicais, o crescimento, o desenvolvimento e a fotossíntese são fortemente afetados por temperaturas baixas, ma s não congelantes. Estes efeitos podem ser ainda mais severos se houver frio combinado a outros fatores adversos, como seca. Porém, a exposição às baixas temperaturas por longos períodos pode promover a aclimatação ao frio, ou desenvolvimento de resistência, um complexo processo que envolve alterações metabólicas, morfológicas e estr uturais, controladas pela expressão de "genes de regulação do frio".

Ramalho et al. (2003) perceberam maior sensibilidade ao frio por parte de $C$. canephora em relação a C. arabica. Trabalhando com a cultivar Apoatã (IAC 2258), os autores perceberam forte inibição da fotossíntese c om a combinação de temperaturas diurnas de $15{ }^{\circ} \mathrm{C}$ e noturnas de $10{ }^{\circ} \mathrm{C}$. DaMatta et al . (1997) relataram que, quando cultivados em altitudes elevadas, $C$. arabica geralmente tem melhor desempenho do que C. canephora, sendo o contrário percebido em terras quentes e de altitudes menores e que daí vem o entendimento de que esta espécie é mais vulnerável ao frio do que aquela. Porém, ao avaliarem parâmetros fotossintéticos de cultivares de ambas as espécies em condições de inverno (temperaturas diur nas de $19,4{ }^{\circ} \mathrm{C}$ e noturnas de 13,9 $\left.{ }^{\circ} \mathrm{C}\right)$ e verão $\left(23,5^{\circ} \mathrm{C} / 19.9^{\circ} \mathrm{C}\right.$, respectivamente), foi confirmada maior sensibilidade ao frio para C. canephora variedade Kouillou. Para eles, então, a diferença d e comportamento entre as espécies em diferentes altitudes não poderia ser justificada por alterações na fotossíntese, mas possivelmente por e feitos das menores temperaturas sobre o armazenamento de fotoassimilados, as relaçõ es fonte-dreno, respiração, hormônios ou outros processos.

Partelli et al. (2009), por outro lado, perceberam diferença signif icativa entre as espécies, no que concerne a parâmetros de atividade fotossintética, com a tendência de maior tolerância ao frio para as variedades de $C$. arabica e menor tolerância para $C$. canephora. As temperaturas testadas por estes autores foram decréscimo de $0,5^{\circ} \mathrm{C}$ por dia de $25 / 20{ }^{\circ} \mathrm{C}$ até $13 / 8{ }^{\circ} \mathrm{C}$ (diurnas/noturnas) e um período de três dias em $13 / 4{ }^{\circ} \mathrm{C}$, com posterior fase de recuperação em $25 / 20^{\circ} \mathrm{C}$. Part elli et al. (2011) relataram que as baixas temperaturas limitam a distribuição geográfica do café quando as temperaturas médias mensais são inferiores a $15-16{ }^{\circ} \mathrm{C}$; a fotossíntese é afetada já abaixo dos $18{ }^{\circ} \mathrm{C}$, e o frio severo tem graves consequências sobre o rendimento. Porém, deixam claro que as 
plantas, devido a sua plasticidade, possuem certa capacidade de aclimatação ao frio, com mecanismos fisiológicos como proteção contra es tresse oxidativo e manutenção de alta estabilidade das membranas celulares.

Cabe ressaltar, também, que as temperaturas testada por Ramalho et al. (2003), DaMatta et al. (1997), e Partelli e colaboradores (2009; 2011) não são comuns no inverno do Cerrado do Brasil Central. Considerando, ainda, a região do Cerrado Baiano, atual fronteira de expansão da cultura, tai s valores também são pouco frequentes.

Fernandes et al. (2012) relataram que a definição d as estações climáticas, com verão quente e úmido e inverno ameno e seco, constitui-se no grande trunfo do Cerrado para a produção do café, pois segundo estes autores estas condições climáticas são importantes para a obtenção de excelente qualidade de café. Segundo estes autores isto ocorre pelo fato do Cerrado se localizar em área continental, possibilitando padrões de chuva diferentes daqueles observados em outras regiões produtoras brasileiras, que sofrem influência das massas oceânicas. No ano de 2005, o Cerrado foi reconhecido como a primeira denominação geográfica de café arábica do Brasil e do mundo, de acordo com normas da Organização Mundial de Proprie dade Intelectual (OMPI), ganhando status semelhante ao das famosas regiões produtoras de vin ho (Café do Cerrado 2010).

De acordo com Ortega e Jesus (2011), devido ao relevo dominante nas regiões de cultivo de café do Cerrado, a mecanização é comum em praticamente todas as etapas do processo produtivo, desde o preparo de solo até a colheita, crescente a cada ano. Segundo os mesmo autores, a colheita mecânica exigi u inovações tecnológicas. Dentre estas, "inovações biológicas", ou seja, relacionada s ao melhoramento genético, são de grande importância, como a obtenção ou introdução d e plantas cujos frutos se desprendem dos ramos com maior facilidade, de porte baixo, com ramos distribuídos mais uniformemente ao longo do tronco e com maturaç ão uniforme. Estas características têm sido verificadas com maior frequência nas cultivares de café arábica, predominante nos cultivos realizados neste bioma, e podem ser projetadas para o café Conilon. A introdução do café Conilon na região dep ende em grande parte da sua adaptabilidade ao sistema de produção, visto que a sustentabilidade do café no Cerrado passa obrigatoriamente pela mecanização das lavoura s. 


\subsection{Colheita mecanizada de café}

Segundo Silva (2004), a mecanização da colheita tem vital importância na recuperação dos investimentos realizados na lavoura de café arábica, pela possibilidade de otimização das operações de campo e redução de c ustos. Oliveira et al. (2007a) relataram que a colheita mecanizada proporcionou uma redução de custos superior a $62 \%$ em relação à colheita manual do café. É também a operação mais complexa, pois se processa em um curto período de tempo e é cercada de diversas dificuldades pela desuniformidade de maturação e umidade dos frutos e pelo formato das plantas (Filgueiras, 2001).

A falta de uniformidade da maturação dos frutos se dá pelo fato de o cafeeiro ser uma espécie de florescimento gregário, ou seja,todas as plantas de uma região florescem ao mesmo tempo, e com número de florações variável em regiões de clima tropical ou equatorial. Desta forma, no Sudeste do Brasil ocorrem de duas a três floradas com intensidades decrescentes, enquanto que na Costa Rica ocorrem até 15 (Alvim, 1973, apud Soares et al., 2005). Esta questão pode ser equacionada pelo uso da técnica de estresse hídrico controlado. De acordo com Santinato et al. (2008), um déficit hídrico controlado estimula a quebra de dormência dos botões florais e induz a floração proporcionando a sincronização da florada do cafeei ro.

Guerra et al. (2005) observaram, após quatro anos d e uniformização de florada pelo estresse hídrico moderado em café arábica no Distrito Federal, que as plantas submetidas a esta técnica apresentavam maior altura, maior número de ramos plagiotrópicos e maior número de nós nestes ramos, em relação às plantas que não haviam sido submetidas à mesma situação. Nestes tra tamentos os autores também observaram maior produtividade, pelo maior enchimento dos grãos e ao melhor desenvolvimento vegetativo proporcionados pela maturação uniforme.

Marsetti et al. (2013), no município de Jaguaré (ES), estudaram o efeito de diferentes períodos de suspensão da irrigação na un iformização de florada em cafeeiro conilon, e obtiveram alto grau de sincronização com período de nove semanas de suspensão. Para Souza et al. (2014), a interrupção da irrigação propiciou maiores uniformidade e porcentagem de frutos maduros na maioria dos materiais estudados $(\mathrm{C}$. canephora), percebendo também respostas diferentes de diversos materiais genéticos.

Com relação aos danos causados à planta, Kashima et al. (1986) relataram menor queda de ramos com ramificações em relação àq ueles sem ramificações, após a 
derriça mecânica. As plantas de café Conilon, por p ossuírem vários ramos ortotrópicos, têm um tipo de arquitetura que dificulta ainda maisa colheita mecânica. Neste caso, sugere-se que os ramos devem ser os mais eretos possíveis. Além disto, um sistema de produção de café Conilon com mecanização de colheit a deve priorizar plantas com menor número de ramos ortotrópicos, o que as tornaria mais compactas e facilitaria o alinhamento da lavoura. Ainda, uma planta com maior distância entre ramos plagiotrópicos (entrenós longos no ramo ortotrópico ), por ter mais espaço livre entre estes ramos, permitiria com maior facilidade a retirada dos frutos.

A derriça dos frutos é o objetivo do trabalho da máquina e deve ser avaliada em diferentes estádios de maturação dos frutos, cultivares, cafeeiros e condições locais da cultura. A maior ou menor facilidade de derriça dos grãos está associada, entre outros fatores, ao estágio de maturação dos frutos. Na fase inicial de colheita, para C. arabica, quando grande parte dos grãos se encontra no estádio "verde" e "cereja", a máquina terá menor eficiência de derriça (Kashima et al., 1986).Rena et al. (1994) relataram que no café conilon os frutos são mais fortemente aderidos à planta do que os de café arábica, não caindo facilmente quando maduros, característic a que deve interferir na colheita.

De acordo com Crisosto e Nagao (1991), a força nece ssária ao desprendimento dos frutos do cafeeiro é significativamente diferente quando se considera tanto estádios de maturação quanto materiais genéticos distintos. Os mesmos autores observaram que a força necessária para retirar da planta os frutos verdes foi aproximadamente o dobro daquela aplicada para a colheita dos frutos cereja. Para Silva et al. (2010), também a força de desprendimento varia entre cultivares e de acordo com a maturação; estes autores citaram esta variação como um importante fa tor para o gerenciamento da colheita mecanizada.

Silva et al. (2013), trabalhando com café arábica,perceberam mais uma vez diferenças significativas para força de desprendime nto em estádios e cutivares (ou progênies) diferentes. Os autores indicaram ser a orçaf de desprendimento dos frutos um importante e objetivo parâmetro para determinar o m omento de início da colheita mecanizada e seletiva do café, além de ser uma boaferramenta para o gerenciamento da colheita mecanizada. Estes autores observaram, para algumas progênies, relação direta entre a força média de desprendimento dos frutos e eficiência de colheita mecanizada.

Ainda segundo Kashima et al. (1986), a eficiência do recolhimento do café derriçado depende do sistema recolhedor da máquinae da adaptação da planta à colheita 
mecânica. Silva e Salvador (1998) citaram valor médio de 15\% entre frutos que não são derriçados e os que caem no chão. Além disto, para que o recolhimento seja facilitado, a ramificação primária deve ser também ereta, pois nas plantas em que a ramificação é pêndula (formando uma espécie de taça), o recolhimento dos frutos também seria bastante dificultado.

\subsection{Melhoramento genético emC. canephora}

Devido à sua menor importância comercial em relação ao café arábica, ao longo da história existiu menor ênfase da pesquisa científica sobre o melhoramento do café Conilon, que teve sua exploração comercial iniciada no Espírito Santo na década de 1960, geralmente em áreas marginais ao cultivo daquela espécie (Ferrão, 2004). Porém, nos últimos anos foram lançadas diversas cultivares, como a Diamante (ES 8112), a Jequitibá (ES 8122), a Centenária (ES 8132), lançadas em 2013 pelo Instituto Capixaba de Pesquisa, Assistência Técnica e Extensão Rural INCAPER),( e a BRS Ouro Preto, lançada pela Empresa Brasileira de Pesquisa Agropec uária (Embrapa Rondônia).

De acordo com Sera et al. (2002), algumas características do cafeeiro arábica exigem procedimentos especiais para que não se tenh a um melhoramento de baixa eficiência. Dentre estas características, destacamse:- longos períodos para a obtenção de flores e sementes oriundas dos cruzamentos; necessidade de grandes áreas de cultivo, o que eleva o custo e o tempo de avaliações de campo; oscilação anual de produção (bienalidade); necessidade de avaliação da precocid ade e da longevidade de produção, entre outras. Todas estas características, de acordo com estes autores, reduzem os ganhos genéticos de seleção por ano. De qualquer maneira, os ganhos genéticos têm sido significativos, tendo-se como exemplo um grande número de cultivares lançadas nos últimos anos.

Ferrão (2004) citou diversos autores para afirmar q ue a alogamia característica da espécie $C$. canephora garante ampla variabilidade e heterozigose, qualidades muito desejadas em programas de melhoramento genético. Os principais métodos de melhoramento utilizados visam a explorar a variabilidade inerente à espécie, selecionando plantas-matrizes, formando populações e melhorando-as por seleção recorrente, desenvolvendo variedades clonais, híbridos e variedades sintéticas.

Os principais objetivos dos programas de melhoramento de café Conilon são, de acordo com Fonseca, 1999 (apud Rodrigues et al., 2012), elevar a produtividade, 
aumentar a precocidade a longevidade e a estabilidade de produção, obter maior tamanho de grãos, maior uniformidade de maturação, baixo percentual de grãos moca, menores teores de cafeína, resistência a pragas e doenças, arquitetura adequada ao adensamento da lavoura e manejo da planta, tolerânc ia à seca e adaptabilidade a diversos ambientes. Considerando o cultivo de café Conilon no Cerrado, torna-se essencial também a busca por materiais com arquitetura mais adequada à colheita mecanizada e ao plantio irrigado via pivô central, comum na região.

Para iniciar qualquer seleção de materiais a uma no va região de cultivo, um passo inicial extremamente importante é a caracterização da população de trabalho, para definir os critérios de seleção. A ampla variabilidade existente dentro da espécie $C$. canephora exige a caracterização dos genótipos com os quais se deseja trabalhar antes de definir as estratégias de melhoramento ou o método a ser utilizado.

Ferrão (2004) citou diversos autores afirmando que os principais métodos de melhoramento tradicionalmente mais utilizados para $C$. canephora são a seleção clonal, a hibridação e as variedades sintéticas, e que, mais recentemente, as seleções recorrentes inter e intrapopulacional e a halodiploidização tam bém vêm sendo aplicadas.

De acordo com Ferrão (2000), devido à autoincompati bilidade e à facilidade de clonagem presentes em C. canephora, é comum o desenvolvimento de variedades clonais. Devido à grande quantidade de sementes pro duzidas pela espécie, é interessante também, embora bem menos comum, que sejam desenvolvidas também variedades sintéticas de multiplicação por sementes.

\subsection{Parâmetros genéticos}

Para qualquer seleção em programas de melhoramento, se faz necessária a predição dos valores genotípicos e fenotípicos dos indivíduos. Para tanto, Resende et al. (2001) indicaram que a estimativa de parâmetros gen éticos é de fundamental importância. Da mesma forma, de acordo com Cruz e c olaboradores (2004), as estimativas de parâmetros genéticos permitem conhecer a estrutura genética da população e inferir sobre a variabilidade genética desta, além de possibilitarem a predição dos ganhos genéticos e o sucesso do programa de melhoramento. Ademais, são importantes na redefinição dos métodos de melhoramento a serem utilizados, na identificação da natureza da ação dos genes envolvi dos no controle dos caracteres quantitativos, na definição com eficiência de diferentes estratégias de melhoramento 
para obtenção de ganhos genéticos com a manutenção da base genética adequada na população.

Segundo Ferrão et al. (2008), entre os parâmetros g enéticos e fenotípicos que podem auxiliar no direcionamento da seleção de cafe eiros mais promissores destacamse as variâncias genéticas e fenotípicas, as herdabilidades e os progressos genéticos esperados. Com relação à herdabilidade, os mesmos a utores afirmam ser fundamental que ela seja a mais real possível, pela sua importâ ncia na predição dos ganhos genéticos de uma característica. Isto vai depender do controle experimental, do número de anos de experimentação, da característica avaliada, do méto do de estimação e da natureza da unidade de seleção.

Em qualquer programa de melhoramento é fundamental estimar o quanto das diferenças fenotípicas se deve à constituição gênic a ou à interferência ambiental (Allard, 1999, apud Amabile, 2013). A herdabilidade mede esta correspondência e foi Lush o primeiro a predizê-la, definindo-a como sendo a proporção genética da variância fenotípica total, em 1940. Segundo este autor, após a escolha do método de melhoramento e do objetivo a ser alcançado, a herda bilidade é o parâmetro genético mais importante a ser estimado. Dessa forma, ela possui um papel preditivo, possibilitando prever o sucesso com a seleção (Rama lho et al., 2008), sendo possível guiar de maneira mais eficiente o programa de melhoramento, calcular o sucesso da forma de seleção adotada e decidir, com embasamento científico, as técnicas alternativas que podem ser mais eficazes (Cruz \& Regazzi, 2001), uma vez que expressa a confiança do valor fenotípico como uma estimativa do valor genético (Falconer \& Mackay, 1996).

A herdabilidade não é um parâmetro imutável, e também não é uma propriedade apenas da característica, sendo ainda da população e do ambiente a que indivíduos ou famílias estejam expostos (Borém \& Miranda, 2005). Assim, deve-se ter o cuidado ao comparar a estimativa da herdabilidade de uma mesma característica, pois em função da amostragem, repetição e tamanho da par cela, das diferenças populacionais

e ambientais, a estimação pode apresentar grande di ferença (Vencovsky, 1970). Comparações podem ser feitas desde que as condições experimentais sejam equivalentes (Robinson, 1963). Ainda, seu cálculo ofres influência, dentre diversos fatores, do efeito ambiental, da forma de propagaçã o da espécie, do grau de endogamia e da diversidade da população em si, da unidade sel etiva (indivíduo ou família), do 
tamanho da amostra analisada e da unidade experimental e, por fim, pela precisão na condução do ensaio e coleta dos dados (Borém \& Miranda, 2005).

A herdabilidade pode ser de dois tipos: no sentido amplo e no sentido restrito. Herdabilidade no sentido amplo é definida como sendo a proporção entre a variância genotípica $\left(\mathrm{V}_{\mathrm{g}}\right)$ e a variância fenotípica $\left(\mathrm{V}_{\mathrm{p}}\right)$. Representa toda a variância genética, ou seja, variância genética aditiva somada à variância genética dominante e epistática, onde a relação entre a $V_{g}$ e $V_{p}$ corresponde a um coeficiente de regressão linear ( $b_{x y}$ ). Herdabilidade no sentido restrito é a relação entre a variabilidade observada causada apenas por efeitos aditivos dos genes e a variância fenotípica, e é tida como a mais importante para o melhoramento, uma vez que representa toda a genética efetivamente fixada na seleção (Amabile, 2013, citando Allard, 1 999; Falconer \& Mackay, 1996).

De acordo com Allard (1999), a herdabilidade, tanto no sentido amplo como no sentido restrito, pode variar de 0 a 1 . No caso de $\mathrm{h}^{2}=0$, a variabilidade da característica não tem origem genética, não havendo assim correlaç ão entre o valor genético e o valor fenotípico do indivíduo ou família. Quando $\mathrm{h}^{2}=1$, o fenótipo é determinado integralmente pelo genótipo, não tendo influência ambiental na característica.

A variação fenotípica que se observa em determinada população se deve à ação conjunta do ambiente e do genótipo (Allard, 1999). De acordo com Amabile (2013), a eficiência do melhoramento genético depende do conhecimento da base genética dos caracteres a serem melhorados, sendo essencial o estudo do componente genético da variância. Para Borém (2009), a variância genética pode ser compreendida como a variação herdável que se mantém nas gerações seguintes. Fisher, estudando em 1918 a covariância e a correlação genética entre parentes, dividiu a variância genotípica de uma população em três componentes: (1) uma parte aditiva, em razão do efeito médio dos alelos; (2) um componente dominante, devido à inter ação entre os alelos do mesmo loco; e (3) uma parte epistática ou interativa, proveniente das interações entre alelos de locos distintos (Allard, 1999). É citada, ainda, a existência de um componente sobredominante em caracteres quantitativos (Borém,2009).

A eficiência da seleção no melhoramento necessita da predição dos valores genéticos, que dependem e podem ser estimados a partir dos componentes de variância genética e fenotípica (Ramalho et al., 2000; Smith et al., 2001; Cruz et al., 2004). Por meio da razão entre as variâncias genéticas e fenotípicas pode-se estimar a herdabilidade e a acurácia, que quantificam a precisão nas predições das médias 
genotípicas a partir das médias fenotípicas (Resende \& Duarte, 2007; Cargnelutti Filho \& Storck, 2009; Storck et al., 2010). Rossmann (2001) afirmou que a variabilidade fenotípica pode ser conhecida por meio dos coeficientes de correlação fenotípica, genotípica e ambiental, das variâncias genotípicas e fenotípicas, entre outros parâmetros que refletem a natureza do material genético e a ação do ambiente.

Por sua vez, à razão entre os coeficientes de varia ção genotípica $(\mathrm{CV}$ g) e ambiental $\left(\mathrm{CV}_{\mathrm{e}}\right)$, dá-se o nome de índice de variação (Vencovsky, 1987), ou simplesmente relação $\mathrm{CV}$ g/ $\mathrm{CV}_{\mathrm{e}}$, ou coeficiente de correlação relativa $(\mathrm{CV}$ r). Este é um importante indicador das possibilidades de sucesso na obtenção de ganhos genéticos por meio de seleção, apresentando uma situação mais fav orável quando os valores são maiores que a unidade, o que obviamente comprovaria que a variação genética supera a ambiental.

A repetibilidade é um parâmetro genético que expresa a proporção da variância total que é explicada pelas variações pro porcionadas pelos genótipos e pelas alterações permanentes atribuídas ao ambiente comum que atuam nos genótipos, e por meio do seu estudo pode-se estimar o número de medições necessárias para predizer o valor real de um genótipo (Cruz e Regazzi, 2001). A lém disso, a repetibilidade fornece o valor máximo que a herdabilidade no sentido amplopode atingir, expressando a proporção da variância fenotípica que é atribuída à s diferenças genéticas confundidas com os efeitos permanentes que atuam sobre o material (Silva et al., 2009).

O conhecimento do coeficiente de repetibilidade das características de interesse permite avaliar o dispêndio de tempo e de mão de obra necessários para que a seleção de indivíduos geneticamente superiores seja feita com a acurácia desejada pelo pesquisador (Della Bruna et al., 2012). Valores altos para repetibilidade do caráter permitem predizer o valor real dos indivíduos com um número relativamente pequeno de medições (Cornacchia et al., 1995), indicando que haverá pouco incremento da acurácia com o aumento do número de medições (Falconer, 1987). No entanto, para Della Bruna et al. (2012), quando a repetibilidade é baixa, grande número de repetições será necessário para que se alcance um valor de determinação satisfatório. Assim, o coeficiente de repetibilidade permite ao melhorista ter maior eficiência na fase de avaliação, com redução do tempo e da mão de obra ne cessários à sua conclusão. 


\subsection{Ferrugem do cafeeiro (Hemileia vastatrix Berk \& Br.)}

A ferrugem do cafeeiro, causada pelo fungo Hemileia vastatrix Berkeley \& Broome é, de acordo com Van der Vossen (2005) a doença mais importante dentre as que atacam esta cultura. Para Zambolim (2002), os as perdas podem atingir 50\% da produção. Para Silva et al. (2014), injúrias causad as por pragas e doenças como a ferrugem e a cercosporiose levam o cafeeiro a desenvolver mecanismos de defesa os quais podem levar a alterações na composição químic a dos grãos crus, tendo como consequência, após a torração, diferentes perfis se nsoriais. Assim, além de seu impacto na produção, as doenças do cafeeiro, entre elas a f errugem, podem alterar a qualidade do produto final.

Hemileia vastatrix Berk \& Br. é um basidiomiceto (Alexopoulos et al., 1996) cujo principal dano causado é a desfolha precoce, a qual resulta em redução da área foliar e seca de ramos laterais, enfraquecendo gradualmente a planta atacada (Carvalho et al., 2010). Dentre os fatores que favorecem a doença, d e acordo com os mesmos autores, estão a alta densidade de plantas suscetív eis, condições de alto enfolhamento de plantas, temperaturas entre $21 \mathrm{e} 23{ }^{\circ} \mathrm{C}$. Existe tamb ém uma tendência para o aumento da severidade da infecção em anos de altas produtivida des.

Herrera et al. (2009) afirmam que a resistência do cafeeiro à ferrugem é associada à taxa de progresso da epidemia e ao equi líbrio da folhagem no campo. Desta forma, materiais resistentes teriam baixa taxa de progresso da doença e desfolha menor. Assim, de acordo com Pereira (2012), as estratégiasque vem sendo desenvolvidas nos atuais programas de melhoramento para resistência à ferrugem do cafeeiro (especialmente para o café arábica) buscam a combinação da resistência específica (completa) e não específica (parcial).

A obtenção de variedades de cafeeiros com resistência durável à ferrugem tem sido dificultada pela grande variabilidade genética de $H$. vastatrix Berk \& Br., característica muito comum à maioria de patógenos b iotróficos, especialmente os causadores de ferrugens (Silva, 2000). Pereira (2012) afirmou que nove genes de resistência à ferrugem, identificados pela sigla $S$, já foram encontrados em diferentes

espécies do gêneroCoffea, especialmente C. arabica, C. canephora e C. liberica. Em $C$. canephora foram encontrados os genes $\mathrm{S}_{\mathrm{H}} 6,7,8$ e 9. Com isto, diversos cruzamentos vêm sendo feitos entre as espécies $C$. arabica e $C$. canephora, resultando em híbridos interespecíficos como o Híbrido de Timor, por exemplo, resultante do cruzamento 
natural entre estas espécies. Este genótipo foi utilizado em diversos programas de melhoramento de café arábica como fonte de resistência à ferrugem, por apresentar, além desta característica, produtividade superior a outros híbridos, fenótipo semelhante ao do café arábica, autofertilidade, menor porcentagem de cafeína comparado ao café robusta e qualidade de bebida regular (Rodrigues Jr. et al., 1975). Desta forma, a caracterização de materiais de C. canephora com relação à sua reação à ferrugem é útil tanto para o melhoramento de café Conilon quanto docafé arábica.

\subsection{Cercosporiose do cafeeiro (Cercospora coffeicola Berkeley \& Cooke)}

Outra importante doença do cafeeiro é a cercosporiose ou mancha-de-olhopardo, causada pelo fungo Cercospora coffeicola Berk. \& Cooke (Pereira, 2012). O fungo é um ascomiceto que pode causar sintomas em folhas e frutos, e ataca o café desde a fase de viveiro até lavouras adultas (Zambolim et al., 2005).

De acordo com Carvalho (2002), são mais suscetíveis à doença lavouras cultivadas em solos arenosos, com nutrição deficien te ou desequilibrada (especialmente na relação N/K).

Uma importante estratégia de controle para a cercosporiose e outras doenças do cafeeiro é a utilização de cultivares resistentes. Entretanto, a resistência à cercosporiose está sendo pouco estudada no Brasil, provavelmenteporque os esforços da pesquisa se concentraram no desenvolvimento de cultivares resistentes à ferrugem, a mais importante doença da cultura, ou pelo fato de ser e ssa doença considerada de pouca importância para a cultura ou estar relacionada com deficiências na nutrição dos cafeeiros (Patrício et al., 2010).

Fernandes et al. (1990), testando diversas progênies de Catimor (cruzamento de Híbrido de Timor com Caturra) com relação à sua rea ção à cercosporiose, verificaram que cinco destas progênies tiveram menor severidade da doença, embora nenhum material tenha se mostrado plenamente resistente. Em trabalho desenvolvido por Patrício e colaboradores (2010), as progênies deC. canephora testadas se mostraram altamente suscetíveis à cercosporiose. Desta forma, nota-se a importância da busca por materiais desta espécie com maiores níveis de tolerância ou resistência à doença. 


\section{REFERÊNCIAS BIBLIOGRÁFICAS}

ALLARD, R. W. Principles of plant breeding. 2ed. Nova Iorque: John Wiley \& Sons, 1999. $254 \mathrm{p}$.

AMABILE, R. F. Caracterização molecular, morfoagronômica e de qual idade de grãos de genótipos elite de cevada irrigada no Cerr ado. 2013, 220 f. Tese (Doutorado). Universidade de Brasília, Brasília, 2013.

BARROS, R. S.; MOTA, J. W. S.; DAMATTA, F. M.; MAESTRI, M. Decline of vegetative growth in Coffea arabica L. in relation to leaf temperature, water potential and stomatal conductance. Field Crops Research, Madison, v. 54, n. 1, p. 65-72, 1997.

BELAN, L. L.; SILVA, K. G.; TOMAZ, M. A.; JESUS JUNIOR, W. C.; AMARAL, J. A. T.; AMARAL, J. F. T. Aspectos fisiológicos do ca feeiro Conilon: uma abordagem sistemática.Nucleus, v. 8, n. 1, p. 225-239, 2011.

BORÉM, A (Ed.). Hibridação artificial de plantas . Viçosa: UFV, 2009. 625 p.

BORÉM, A.; MIRANDA, G. V. (Eds.). Melhoramento de plantas. 4. ed. Viçosa: UFV, 2005. 525 p.

BORLAUG, N. E. Feeding a world of 10 billion people: the miracle ahead. In: BAILEY, R. (Ed.). Global warming and other eco-myths. Roseville, EUA: Competitive Enterprise Institute, p. 29-60.

BRAGANÇA, S. M.; CARVALHO, C. H. S.; FONSECA, A. F. A.; FERRÃO, R. G. Variedades clonais de café Conilon para o Estado do Espírito Santo. Pesquisa Agropecuária Brasileira, Brasília, v. 36, n. 05, p. 765-770, 2001.

CARGNELUTTI FILHO, A.; STORCK, L. Medidas do grau de precisão experimental em ensaios de competição de cultivares de milho. Pesquisa Agropecuária Brasileira, v. 44, p. 111-117, 2009. 
CARVALHO, A.; MEDINA FILHO, H. P.; FAZUOLI, L. C.; GUERREIRO FILHO, O.; LIMA, M. M. A. Aspectos genéticos do cafeeiro.Revista Brasileira de Genética, v. 14, n. 1, p. 135-183, 1991.

CARVALHO, F. I. F.; LORENCETTI, C.; BENIN, G. Estimativas e implicações da correlação no melhoramento vegetal . Pelotas: UFPel, 2004. 142p.

CARVALHO, H. P. Avaliação de cultivares de cafeeiro ( Coffea arabica L.) nas condições de Cerrado em Uberlâdia. 2002. 29f. Trabalho de conclusão de curso Instituto de Ciências Agrárias, Universidade Federal de Uberlândia, Uberlândia - MG, 2002.

CARVAlHO, L. C.; CHALfOUN, S. M.; CUNHA, R. L. Manejo de doenças do cafeeiro. In: REIS, P. R.; CUNHA, R. L. (Eds.). Café arabica: do plantio à colheita. Lavras: Epamig, 2010. v. 1, p. 689-757.

CHARRIER, A.; BERTHAUD, J. Principles and methods in Coffea plant breeding: Coffea canephora Pierre. In: MACRAE, R.; CLARCK, R. J.. (Eds.). Coffea Agronomy. London: Elsivier, 1988. v. 6, p. 167-195.

CHEVALIER, A. Ern les caféiers du globe. LECHEVALIER (Ed.). Paris: Fas. 1, 1929. $196 \mathrm{p}$.

CHAVALIER, A. Ern le café. Paris: Preses Universitaires de France, 1944. 124 p.

CONAB. Companhia Nacional de Abastecimento. Acompanhamento da Safra Brasileira de Café.Safra 2015 - quarto levantamento. Dezembro/2015. Di sponível em: <www.conab.gov.br/OlalaCMS/uploads/arquivos/15_12_17_09_02_47_boletim_cafe_d ezembro_2015_2.pdf> Acesso em 24/05/2016.

CORNACCHIA, G.; CRUZ, C.D.; LOBO, P.R.; PIRES, I.E. Estimativas do coeficiente de repetibilidade para características fenotípicas de procedências dePinus tecunumanii (Schw.) Eguiluz, Perry e Pinus caribaea var. hondurensis Barret, Golfari. Revista Árvore, Viçosa, v.19, n.3, p.333-345, 1995. 
CRISOSTO, C. H.; NAGAO, M. A. Evaluation of fruit remove force on coffee cultivars. HortScience, v. 26, n. 2, p. 210-230. 1991.

CRUZ, C. D.; REGAZZI, A. J.; CARNEIRO, P. C. S. Modelos biométricos aplicados as melhoramento genético. 3. ed. Viçosa: UFV, 2004. v. 1, 480 p.

CRUZ, C. D.; REGAZZI, A. J. Modelos biométricos aplicados ao melhoramento genético. 2. ed. Viçosa: UFV, 2001. 390 p.

CRUZ, C. D. Programa Genes: aplicativo computacional em genética e estatística. Versão Windows 2007. Viçosa: UFV, 2007.

DAVIS, A. P., GOVAERTS, R.; BRIDSON, D. M.; STOFFELEN, P. An annotated taxonomic conspectus of the genus Coffea (Rubiaceae). Botanical Journal of the Linnean Society, v. 152, n. 4, p. 465-512, 2006.

DaMATTA, F. M.; MAESTRI, P. R. M.; MOSQUIM, P. R.; BARROS, R. S. Photosynthesis in coffee (Coffea arabica and C. canephora) as affected by winter and summer conditions. Plant Science. v. 128, p. 43-50. 1997.

DELlA BRUNA, E.; MORETO, A. L.; DALBÓ, M. A. Uso do coeficiente de repetibilidade na seleção de clones de pessegueiro para o litoral de Santa Catarina.

Revista Brasileira de Fruticultura, v. 34, n. 1, p. 206-215. Março, 2012.

FALCONER, D. S. Introdução à genética quantitativa . Viçosa: UFV, 1987, 279 p.

FALCONER, D. S.; MACKAY, T. F. C. Introduction to quantitative genetics. 4a ed. Edinburgh: Longman Group Limited, 1996. 464 p.

FAZUOLI, L.C. Genética e melhoramento do cafeeiro. In: RENA, A. B.; MALAVOLTA, E.; ROCHA, M.; YAMADA, T.. (Eds.). Cultura do cafeeiro: fatores que afetam a produtividade. Piracicaba: POTAFOS, 1986, p. 87-114.

FERNANDES, A. L. T.; PARTELli, F. L.; BONOMO, R.; GOLYNSKI, A. A moderna cafeicultura dos Cerrados brasileiros. Pesquisa Agropecuária Tropical, v. 42, n 2, p. 231-240, 2012. 
FERNANDES, A.T.F.; VALE, F.X.R.; PELOSO, M.C.; ZAMBOLIM, L.; MAFFIA, L.A.; PEREIRA, A.A.; CHAVES, G.M.; CRUZ FILHO, J. Resistência de progênies de Catimor a diferentes isolados de Cercospora coffeicola Berk. \& Cook. Fitopatologia Brasileira, v. 15, p.45-49, 1990.

FERRÃO, R. G. Biometria aplicada ao melhoramento genético do caféconilon. 2004. 256f. Tese (Doutorado em Genética e Melhoramento). Universidade Federal de Viçosa. Viçosa, 2004.

FERRÃO, R. G.; CRUZ, C. D.; FERREIRA, A.; CECON, P. R.; FERRÃO, M. A. G.; FONSECA, A. F. A.; CARNEIRO, P. C. S.; SILVA, M. F. Parâmetros genéticos em café conilon.Pesquisa Agropecuária Brasileira, v. 43, n. 1, p. 61-69, jan. 2008.

FERRÃO, Romário Gava et al. EMCAPER 8151 - Robusta tropical: variedade melhorada de café conilon de propagação por sementes para o estado do Espírito Santo. In: Simpósio de pesquisa dos cafés do Brasil, 1. Poços de Caldas, 2000. Resumos expandidos.. Brasília. Embrapa Café, 2000.

FERRÃO, M. A. G.; FERRÃO, R. G.; FONSECA, A. F. A.; VERDIM FILHO, A. C.; VOLPI, P.S. Origem, dispersão geográfica, taxonomia e diversidade genética de Coffea canephora. In: FERRÃO, R. G.; FONSECA, A. F. A.; BRAGANÇA, S. M.; FERRÃO, M. A. G.; DE MUNER, L. H. (Eds.). Café conilon.Vitória: Incaper, 2007. $702 p$.

FILGUEIRAS, W. H. Modelagem da planta de café por elementos finitos para estudos de colheita por vibração. 2001. 81f. Dissertação (Mestrado em Mecanização Agrícola). Universidade Federal de Viçosa, Viçosa, 2001.

FONSECA, A. F. A.; SEDIYAMA, T.; CRUZ, C. D.; SAKAIYAMA, N. S.; FERRÃO, M. A. G.; FERRÃO, R. G.; BRAGANÇA, S. M. Divergênci a genética em café Conilon. Pesquisa Agropecuária Brasileira, v. 41, n. 6, p. 599-605, 2006.

GUERRA, A. F.; ROCHA, O. C.; RODRIGUES, G. C.; SANZONOWICZ, C.; SAMPAIO, J. B. R.; SILVA, H. C.; ARAÚJO, M. C. Irrigação do cafeeiro no Cerrado: Estratégia de manejo de água para uniformização de florada. Planaltina, DF: Embrapa Cerrados, 2005. 4p. (Comunicado Técnico, 122). 
HERRERA, P. J. C.; AlvarAdo, G. A.; CORTINA, H. A. G.; COMBES, M. C.; ROMERO, G. G.; LACHERMES, P. Genetic analysis of partial resistance to coffee leaf rust (Hemileia vastatrix Berk \& Br.) introgressed into the cultivated Coffea arabica $\mathrm{L}$. from the diploid C. canephora species. Euphitica, v. 167, n. 1, p. 57-67, 2009.

KASHIMA, T.; HONDA, A. I.; FAVA, J. F. M.; BASTOS, M. V.; SARTORI, S. Colheita mecânica do café. In: RENA, A. B.; MALAVOLTA, E.; ROCHA, M.; YAMADA, T. (Eds.). Cultura do cafeeiro: fatores que afetam a produtividade.

Piracicaba: POTAFÓS, 1986. p. 409-418.

KLINK, C. A.; MACHADO, R. B. A conservação do Cerra do brasileiro. Megadiversidade,v.1,n.1, julhode 2005. Disponívelem:

$<$ http://www.equalisambiental.com.br/wpcontent/uploads/2013/02/Cerrado_conservacao.pdf> Acesso em 28/11/2014.

LUSH, J. L. Intra-sire correlations on regressions of offispring on dam as a method of estimating heritability of characteristics. Journal of Animal Science, p. 293-301, 1940.

OLIVEIRA, E.; SILVA, F. M.; SALVADOR, N. Influênciada vibração das hastes e da velocidade de deslocamento da colhedora no processo de colheita mecanizada do café. Engenharia Agrícola, v. 27, n. 3, p. 714-721, 2007.

OLIVEIRA, E.; SILVA, F. M.; SALVADOR, N.; SOUZA, Z. M.; CHALFOUN, S. M.; FIGUEIREDO, C. A. P. Custos operacionais da colheita mecanizada do cafeeiro.

Pesquisa Agropecuária Brasileira, v.42, n.6, p.827-831, jun. 2007.

ORTEGA, A. C.; JESUS, C. M. Território café do Cerrado: transformações na estrutura produtiva e seus impactos sobre o pessoal ocupado. Revista Economia Sociologia Rural, v. 49, n. 3, p. 771-800, 2011.

PARTELlI, F. L.; VIEIRA, H. D.; VIANA, A. P.; BATISTA-SANTOS, P.; RODRIGUES, A.P.; LEITÃO, A. E.; RAMALHO, J. C. Low temperature impatc on photosyntetic parameters on coffee genotypes. Pesquisa Agropecuária Brasileira,v. 44, n. 11, p. 1404-1415, 2009. 
PARTELli, F. L.; BATISTA-SANTOS, P.; SCOTTI-CAMPOS, P.; PAIS, I. P.; QUARTIN, V. L.; VIEIRA, H. D.; RAMALHO, J. C. Characterization of the main lipid components of chloroplast membranes and cold induced changes in Coffea spp.

Environmental and Experimental Botany, v. 74, n. 1, p. 194-204, 2011.

PATRÍCIO, F. R. A.; BRAGHINI, M. T.; FAZUOLI, L. C. Resistência de plantas de Coffea arabica, Coffea canephora e híbridos interespecíficos à cercosporiose. Bragantia, v. 69, n. 4, p. 883-890, 2010.

PEREIRA, T. B. Seleção de progênies de F4 de cafeeiros utilizando o procedimento REML/BLUP. 2012, 60 f. Dissertação (Mestrado em Fitotecnia). Universidade Federal de Lavras. Lavras, 2012.

RAMALHO, M. A. P.; FERREIRA, D. F.; OLIVEIRA, A. C. Experimentação em genética e melhoramento de plantas. Lavras: UFLA, 2000. 326 p.

RAMALHO, M. A. P.; SANTOS, J. B. dos; PINTO, C. B. Genética na agropecuária. 4a ed. Lavras: UFLA, 2008. 463 p.

RAMALHO, J. C.; QUARTIN, V. L.; LEITÃO, E.; CAMPOS, P. S.; CARELLI, M. L. C.; FAHL, J. I.; NUNES, M. A. Cold acclimation ability and photosynthesis among species of the tropical Coffea genus. Plant Biology, v. 5. p. 631-641, 2003.

RENA A. B.; BARROS, R. S.; MAESTRI, M.; SÖNDAHL, M. R. Coffee. In: SCHAFTER, B.; ANDERSEN, P. C. (Eds.). Handbook or environmental physiology of fruits crops: sub-tropical and tropical crops. Boca Raton: CRC Press, 1994. v.2, p. 101-122.

RESENDE, M. D. V. de; DUARTE, J. B. Precisão e cont role de qualidade em experimentos de avaliação de cultivares. Pesquisa Agropecuária Tropical, v. 37, n. 3, p. 182-194, 2007.

RESENDE, M. D. V.; FURLANI JÚNIOR, E.; MORAES, M. L . T.; FAZUOLI, L. C. Estimativas de parâmetros genéticos e predição de $\mathrm{v}$ alores genotípicos no melhoramento do cafeeiro pelo procedimento REML/BLUP. Bragantia, v. 60, p. 185-193, 2001. 
RODRIGUES, W. N.; TOMAZ, M. A.; FERRÃO, R. G.; FERR ÃO, M. A. G.;

FONSECA, A. F. A.; MIRANDA, F. D. Estimativa de parâmetros genéticos de grupos de clones de café conilon.Coffe Science, v. 7, n. 2 p. 177-186, 2012.

RODRIGUES JÚNIOR, C. J.; BETTENCOURT, A. J.; RIJO, L. Races of the pathogen and resistance to coffee rust. Ann. Review of Phytopathology, v.13, p.49-70, 1975.

RONCHI, C. P.; DAMATTA, F. M. Aspectos fisiológicos do café conilon. In: FERRÃO, R. G.; FONSECA, A. F. A.; BRAGANÇA, S. M.; FERRÃO, M. A. G.; DE MUNER, L. H. (Eds.). Café conilon. Vitória: Incaper, 2007. 702p.

ROSSMANN, H. Estimativas de parâmetros genéticos e fenotípicos de uma população de soja avaliada em quatro anos . 2001. 91f. Dissertação (Mestrado). Universidade de São Paulo. Escola Superior de Agric ultura "Luiz de Queiroz". Piracicaba, 2001.

SANTINATO, R.; FERNANDES, A. L. T.; FERNANDES, D. R. Irrigação na cultura do café.2.ed. Belo Horizonte: O Lutador, 2008. 476p.

SERA, T.; ALTEIA, M. Z.; PETEK, M. R. Melhoramento do cafeeiro - variedades melhoradas no Instituto Agronômico do Paraná (IAPAR). In: ZAMBOLIM, L. (Ed). O estado da arte de tecnologias na produção de café - IV Encontro sobre Produção de Café com Qualidade. Viçosa: UFV, 2002. p. 217-251.

SILVA, A. C. A.; ABREU, G. F.; MACEDO, D. D.; RIBEIRO, D. E.; VOLTOLINI, G. B.; AlVES, G.; SILVA, A. D.; GUIRALDELI, C. H. C. Fitossanidade do cafeeiro: relação com a qualidade sensorial. SIMPÓSIO DE PESQ UISA DOS CAFÉS DO BRASIL, 9, 2015. Anais.. Curitiba, 2015.

SIlVA, C. S.; SIlVA, F. M.; ALVES, M. C.; BARROS, M. M.; SALES, R. S. Comportamento da força de desprendimento de frutos de cafeeiros ao longo do período de colheita. Ciência e Agrotecnologia,v. 34, n. 2, p. 468-474, 2010.

SIlvA, F. C.; SIlVA, F. M.; SIlvA, A. C.; BARROS, M. M.; PALMA, M. A. Z. Desempenho operacional da colheita mecanizada e seletiva do café em função da força de desprendimento dos frutos. Coffee Science, v. 8, n. 1, p. 53-60, 2013. 
SILVA, D. G. Levantamento de raças fisiológicas de Hemileia vastatrix Berk \& Br. e resistência de clones deCoffea canephora var. Conilon à ferrugem. 2000, 80f. Tese (Doutorado em Fitopatologia). Universidade Federal de Viçosa. Viçosa, 2000.

SILVA, F. M. Colheita mecanizada e seletiva do café. Cafeicultura empresarial: produtividade e qualidade. Lavras: UFLA/FAEPE, 2004. 75 p.

SILVA, F. L.; OLIVEIRA, A. C. B.; PEREIRA, A. A.; BOTELHO, C. E.; REZENDE, J. C.; CARVAlHO, G. R. Repetibilidade e número de colheitas para seleção de progênies de café arábica. CONGRESSO BRASILEIRO DEMELHORAMENTO DE PLANTAS, 5, 2009. Anais. Vitória, ES. 2009.

SMITH, A.; CULLIS, B.; THOMPSON, R. Analyzing variety by environment data using multiplicative mixed models and adjustments for spatial field trend. Biometrics, v. 57, n. 4, p. 1138-1147, 2001.

SOARES, A. R.; MANTOVANI, E. C.; RENA, A. B.; SOARES, A. A. Irrigação e fisiologia da floração em cafeeiros adultos na regi ão da zona da mata de Minas Gerais. Acta Scientiarum Agronomy, v.27, n.1, p.117-125, 2005.

SOUZA, J. M.; BONOMO, R.; MAGIERO, M.; BONOMO, D. Z. Interrupção da irrigação e maturação dos frutos de café conilon. Científica, v. 42, n. 2, p. 170-177, 2014.

VAN DER VOSSEN, H. A. M. State-of-the-art of developing durable resistance to biotrophic pathogens in crop plants, such as Coffee Leaf Rust. In: ZAMBOLIM, L.; ZAMBOLIM, E.; VÁRZEA, V. M. P. (Eds.). Durable resistance to coffee leaf rust. Universidade Federal de Viçosa, 2005, p 1-30.

VENCOVSKY, R. Herança quantitativa. In: PATERNIANI, E.; VIEGAS, G. P. (Eds.). Melhoramento e produção de milho . 2.ed. Campinas: Fundação Cargill, 1987. v.1. $795 \mathrm{p}$.

ZAMBOLIM, L. Epidemiologia e controle integrado da ferrugem do cafeeiro. In: ZAMBOLIM, L. (Ed.). O estado da arte das tecnologias na produção de caf é. Viçosa: Editora UFV, 2002, p. 369-433. 
ZAMBOLIM, L.; VALE, F. X. R.; ZAMBOLIM, E. M. Doenç as do cafeeiro (Coffea arabica e C. canephora). In: KIMATI, H.; AMORIM, L.; REZENDE, J. A. M.; BERGAMIN FILHO, A.; CAMARGO, L. E. A. (Eds.). Manual de fitopatologia: doenças das plantas cultivadas. 4.ed. São Paulo: Ag ronômica Ceres, 2005, v.2, p. 165180. 


\title{
Capítulo 1
}

\section{PRODUTIVIDADE, CICLO DE MATURAÇÃO E ESTIMATIVAS DE PARÂMETROS GENÉTICOS DE GENÓTIPOS DE CAFÉ CONILON IRRIGADOS NO CERRADO}

\author{
RESUMO
}

Foi avaliada por três safras a produtividade e o ciclo de maturação de uma população de 85 genótipos de Coffea canephora Pierre ex Froehner no Cerrado do Distrito Federal sob irrigação. O ensaio foi conduzido atrav és do Modelo Básico de Repetibilidade Sem Delineamento, utilizando a metodologia REML/BLUP. A área experimental foi estabelecida em 2009, no espaçamen to de 3,5 m entre linhas e 1,0 m entre plantas, com irrigação por pivô central. Com relação aos ciclos, os genótipos foram divididos em quatro grupos, com os seguintes períodos, em dias, entre o retorno da irrigação e estádio de cereja: Superprecoce (243-255 dias), Precoce (256267), Médio (268-280) e Semitardio (281-293). Paraa produtividade, a repetibilidade obtida foi de aproximadamente $33 \%$, valor considerado médio e que representa a proporção da variância fenotípica permanente em rel ação à variância fenotípica total. A repetibilidade média obtida foi superior a 59\%, e a acurácia, com apenas três safras, chegou a 77\%, sendo necessárias apenas quatro safras para este parâmetro superar os $80 \%$. Foram obtidos também os valores fenotípicos dos genótipos e os ganhos de seleção, que podem ser superiores a 38\%. Existem genótipos promissores para cultivo irrigado no Cerrado do Brasil Central dentro da população estudada e a indicação destes materiais para cruzamentos com o i ntuito de maximizar os efeitos heteróticos e a complementaridade gênica dentro do programa de melhoramento de café conilon irrigado no Cerrado. Há variabilidadegenética dentro da população com base na produtividade e no ciclo de maturação. Os v alores obtidos para repetibilidade favorecem a seleção de genótipos superiores com bas e no fenótipo.

Palavras-chaves: Coffea canephora Pierre ex Froehner, produtividade, repetibilidade, variabilidade fenotípica, melhoramento genético. 


\title{
YIELD AND MATURATION CICLE OF CONILON COFFEE GENOTIPES GROWN IRRIGATED IN THE Cerrado
}

\begin{abstract}
Yield and the maturation cycle of an 85 population of Coffea canephora was evaluated for three years in the Federal District's Cerrado. The essay was conducted through the Repeatability Basic Model Without Experimental Design, using the REML/BLUP methodology. The crop was stablished in 2009, with 3,5 m spacing between rows and $1,0 \mathrm{~m}$ between plants in the row, irrigated by a central pivot. Regarding to the maturation cycles, the genotypes formed four grups, each one with the following period (in days) between te flowering and the cherry stage: Superprecocious (243-255), Precocious (256-267), Medium (268-280) and Medium Late (281-293). For yield, repeatability was approximately 33\%, a medium value that represents the proportion of permanent phenotypic variance between plants relative to total variance. The medium repeatability obtained was above $59 \%$ and the accuracy, with only three years of evaluation, became close to $77 \%$, requiring only one more year to overcome $80 \%$. There were also obtained genotypes' phenotypic values and the selection gains, which can be above $38 \%$. There are promising genotypes for irrigated farming in the Central Brazil's Cerrado in the population studied, and the indication of these materials to cross in order to maximise heterosis effects and gene complementarity within the irrigated conilon coffee breeding program in Cerrado. There is genetic variability within the population based on yield and maturation cicle.
\end{abstract}

Index terms: Coffea canephora Pierre ex Froehner, yield, repeatability, phenotypic variance, crop breeding. 


\section{INTRODUÇÃO}

A espécie Coffea canephora, embora bastante produtiva, é menos plantada no Brasil do que Coffea arabica, ficando praticamente restrita aos estados do Espírito Santo, Rondônia e Bahia. Isto se deve à sua melhor adaptação às condições edafoclimáticas de regiões tropicais de baixas altitudes e temperaturas do ar elevadas (Ferrão, 2004). Assim, seu cultivo não é comum no Cerrado do Brasil Central, onde seu estabelecimento deve passar obrigatoriamente pela seleção de materiais adaptados ao clima e sistema de cultivo da região.

DaMatta et al. (1997) relataram que, quando cultivados em altitudes elevadas, C. arabica geralmente tem melhor desempenho do que $C$. canephora, sendo o contrário percebido em terras quentes e de altitudes menores. Ramalho e colaboradores (2003) perceberam maior sensibilidade ao frio por parte de $C$. canephora em relação a $C$. arabica. Partelli et al. (2011) citam diversos autores relatando que as baixas temperaturas do ar limitam a distribuição geográfica do café, especialmente quando as médias mensais são inferiores a $15-16^{\circ} \mathrm{C}$; a fotos síntese é afetada já abaixo dos $18{ }^{\circ} \mathrm{C}$, e o frio severo tem graves consequências sobre o rendimento. Porém, aqueles autores deixam claro que as plantas possuem certa capacidade de aclimatação ao frio.

O Cerrado tem se mostrado bastante propício à cultu ra do café arábica, especialmente quando utilizadas tecnologias como irrigação e tratos culturais mecanizados (Fernandes, 2012), especialmente a colheita. O mesmo autor citam que a grande limitação de $C$. canephora no Cerrado está associada às baixas temperaturas nas áreas de maior altitude. Porém, devido à grande diversidade genética existente nesta espécie (Fonseca et al., 2006), ela apresenta diferentes mecanismos de tolerância às baixas temperaturas (Partelli et al., 2011), o que permite inferir que pode ser feita seleção de materiais adaptados ao cultivo na região central do Brasil.

De acordo com Sera (2015), em regiões de temperatur as do ar mais amenas não é indicado o plantio de cultivares de ciclo tardio ou muito tardio, pois a colheita pode coincidir com o início da florada, o que pode danificar flores (ou gemas), além do risco de geadas nos frutos verdes. Embora no Brasil Central seja rara a ocorrência de geadas, o uso da colheita mecanizada, amplamente difundido nesta região, pode acarretar perda de produtividade da próxima safra, pelos danos caus ados às flores ou gemas florais em cultivares tardias, especialmente quando não se ado ta a tecnologia do estresse hídrico para uniformização de florada. Desta forma, é de suma importância o estudo e a 
diferenciação do ciclo de maturação de materiais em estudo. Ainda, de acordo com o mesmo autor, as cultivares mais produtivas são as d e ciclo médio ou tardio. Assim, seria de grande valor a identificação de materiais produt ivos de ciclos precoces, especialmente para reduzir os riscos de chuvas durante a colheita.

A repetibilidade é um parâmetro genético que expresa a proporção da variância total que é explicada pelas variações pro porcionadas pelos genótipos e pelas alterações permanentes atribuídas ao ambiente comum que atuam nos genótipos, e por meio do seu estudo pode-se estimar o número de medições necessárias para predizer o valor real de um genótipo (Cruz e Regazzi, 2001). E la fornece o valor máximo que a herdabilidade no sentido amplo pode atingir, expressando a proporção da variância fenotípica que é atribuída às diferenças genéticas confundidas com os efeitos permanentes que atuam sobre o material (Silva et al., 2009). Assim, por meio da repetibilidade pode-se comparar indivíduos distintos por meio de dados colhidos ao longo do tempo, o que é bastante útil quando se considera uma planta alógama altamente heterozigota como o café conilon, sem a necessidade de reproduzir clones de uma população de muitos genótipos distintos. Isto p ermite a avaliação de um grande número de materiais num espaço reduzido.

A predição do BLUP (Melhor Predição Linear Não Vici ada) pressupõe o conhecimento dos valores reais dos componentes de variância, todavia, como isso é inexequível, através de Equações de Modelos Mistos, utilizam-se as estimativas destes componentes. Neste evento, dentre os principais procedimentos para estimação dos componentes de variância, ressalta-se o de Máxima Verossimilhança Restrita (REML), proposto por Patterson e Thompson (1971) e descrito por Lopes et al. (1998). De acordo com Falcão et al. (2009), são vantagens deste método a propriedade de reduzir as tendências, em decorrência da seleção, e a capacidade de utilizar toda informação disponível, o que leva o método a ser largamente utilizado na estimativa dos componentes de variância em conjuntos de dados desb alanceados. 


\section{OBJETIVOS}

- Avaliar, por meio da repetibilidade, a variabilidade fenotípica de uma população de Coffea canephora irrigada no Cerrado do Distrito Federal com relaçã o ao seu desempenho agronômico;

- Determinar, por meio da repetibilidade, os parâmetr os genéticos e fenotípicos de uma população de C. canephora irrigada no Cerrado do Distrito Federal;

- Caracterizar a variabilidade fenotípica de uma população de C. canephora irrigada no Cerrado do Distrito Federal com relação ao ciclo de maturação dos frutos;

- Identificar e selecionar acessos de C. canephora produtivos nas condições do Cerrado do Distrito Federal.

- Avaliar o uso do coeficiente de repetibilidade para a seleção fenotípica em café Conilon. 


\section{MATERIAL E MÉTODOS}

O trabalho foi conduzido no Campo Experimental da Embrapa Cerrados, localizada em Planaltina, Distrito Federal, situada a 15³5'30" latitude S, 47²4'30" longitude $\mathrm{O}$ e altitude de $1.007 \mathrm{~m}$, num solo classificado como LATOSSOLO VERMELHO Distrófico típico, argiloso. Os resultados médios de análise química do solo na profundidade de $0-20 \mathrm{~cm}$ apresentaram os seguintes resultados: $1,14 \mathrm{mmolc} . \mathrm{dm}^{-3}$ de Al; 16,4 mmolc.dm ${ }^{3}$ de Ca; 0,63 mmolc.dm ${ }^{3}$ de K; 2,5 mmolc.dm ${ }^{3}$ de $\mathrm{Mg} ; 59,6$ ppm de P; 27,8 g/kg de matéria orgânica e pH em água de 4,44; areia grossa $=60 \mathrm{~g} \mathrm{~kg}$ ${ }^{1}$; areia fina $=380 \mathrm{~g} \mathrm{~kg}^{-1}$; silte $=130 \mathrm{~g} \mathrm{~kg}^{-1}$ e argila $=430 \mathrm{~g} \mathrm{~kg}^{-1}$.

A área vinha sendo cultivada nos anos anteriores com culturas anuais, e o estabelecimento deste ensaio se deu em abril de 2009, com o espaçamento de 3,5 m entre linhas e 1,0 m entre plantas. Foram avaliados 85 genótipos de $\quad$ C. canephora oriundos de cruzamentos naturais dentro de um campo experimental da variedade Robusta Tropical (EMCAPER 8151), da Empresa Capixaba de Pesquisa e Extensão Rural - EMCAPER - (Ferrão et al ., 2000). O método de irrigação utilizado foi a aspersão, e o sistema adotado foi por pivô central. O critério de manejo da irrigação fundamentou-se no monitoramento do clima, sendo que o momento de irrigação ocorria a cada cinco dias, de acordo com o Programa de Monitoramento de Irrigação do Cerrado (Rocha et al., 2008). Para uniformização da florada, a irrigação era susp ensa em primeiro de julho e retornava sempre que no mínimo $80 \%$ das gemas florais atingiam $80 \%$ do estádio E4, com data limite do retorno da água de irrigação em 4 de setembro de cada ano.

$\mathrm{Na}$ implantação do experimento foram adicionados $120 \mathrm{~g}$ de superfosfato triplo, $50 \mathrm{~g}$ de termofosfato magnesiano (Yoorin ${ }^{\circledR}$ ) e 24,5 $\mathrm{g}$ de fritted trace elements (FTE BR 12) por cova. A calagem foi de duas toneladas por hectare de calcário dolomítico, com o objetivo de elevar a saturação de bases para $50 \%$, sendo metade da dose aplicada antes da aração e a segunda metade, a ntes da gradagem, e também foi feita a aplicação de duas toneladas por hectare de gesso agrícola. A adubação anual consistiu de $450 \mathrm{~kg}$.ha de nitrogênio na forma de ureia, $450 \mathrm{~kg}$.ha de $\mathrm{K}_{2} \mathrm{O}$ na forma de cloreto de potássio, aplicados em quatro parcelas iguais em setembro, dezembro, fevereiro e março, $300 \mathrm{~kg}$.ha ${ }^{-1}$ de $\mathrm{P}_{2} \mathrm{O}_{5}$ usando como fonte o superfosfato simples, sendo dois terços aplicados em setembro e o restante em d ezembro. A cada dois anos, foram 
adicionados mais $100 \mathrm{~kg} \cdot \mathrm{ha}^{-1}$ de FTE BR 12. No primeiro ano foi aplicada apenas a metade da dose anual.

No campo experimental existem cerca de 3500 genótip os, plantados sem repetição e, portanto, sem delineamento experimenta l. Após a colheita das safras de 2011/12, 2012/13 e 2013/14 foram selecionados 85 materiais com produção mínima de sete litros por planta em cada um dos três anos e variação de produção menor que $25 \%$, os quais foram usados na análise estatística, por meio da repetibilidade, para a obtenção dos valores de parâmetros genéticos, valores fenotípicos e determinação da sua produtividade. Observações preliminares, especialme nte aquelas realizadas por Carneiro et al. (2013), permitiram esta pré seleção e ainda que não fossem escolhidos materiais de maturação tardia. Foram calculados o desvio padr ão e o coeficiente de variação da produtividade de cada material ao longo das três safras.

A determinação dos ciclos de maturação foi feita po $r$ meio da observação semanal dos materiais, de acordo com a escala desenvolvida, porém adaptada de Pezzopane et al. (2003), de forma que considerava-se a mudança de nível apenas quando no mínimo $80 \%$ dos frutos se encontravam no mesmo estádio de maturação. Desta maneira considerando o cereja o ponto ideal para a colheita, foi determinado o tempo, em dias, para que cada material atingisse este estágio, contando a partir do florescimento, que se deu em média em 18/09, aproximadamente duas semanas após o retorno da irrigação, ocorrido geralmente em 04/09. A diferença, em dias para atingir o cereja, entre o material mais precoce (243 dias) e o mais tardio (293 dias), foi de 50 dias. Assim, foram feitos três cortes nas medianas(13, 25 e 38 dias, aproximadamente), formando quatro grupos de maturação, os quais foram denominados Superprecoce (243-255 dias), Precoce (256-267), Médio (268-280) e Semitardio (281-293).

A análise estatística foi realizada por meio do Sistema Estatístico e Seleção Genética Computadorizada via Modelos Lineares Mistos, o Selegen - REML/BLUP (Resende, 2007), usando o Modelo Básico de Repetibilidade Sem Delineamento (Modelo 63 do programa). Utilizou-se a Metodologia de Modelos Mistos para a obtenção da Melhor Predição Linear não Viesada (BLU P) dos efeitos genotípicos e o processo da Máxima Verossimilhança Restrita (REML) para a estimação dos componentes de variância e dos parâmetros genotípic os. Algumas vantagens do método, de acordo com Falcão et al.(2009), são a propriedad e de reduzir o viés, em decorrência da seleção, e a capacidade de utilizar toda informa ção disponível, o que leva o método a 
ser largamente utilizado na estimativa dos componentes de variância em conjuntos de dados desbalanceados.

O Modelo Básico de Repetibilidade Sem Delineamentoé usado quando são tomados dados repetidos em plantas individuais sem delineamento experimental definido. O modelo estatístico é $y=X m+W p+e$, em que y é o vetor de dados, m é o vetor dos efeitos de medição (assumidos como fixos) somados à média geral, $\mathrm{p}$ é o vetor dos efeitos permanentes de plantas (efeitos genotípicos mais efeitos de ambiente permanente, assumidos como aleatórios) e $e$ é o vetor de erros ou resíduos (aleatórios). As letras maiúsculas representam as matrizes de incidência para os referidos efeitos.

Foram obtidos, então, os valores do coeficiente de repetibilidade, o qual, neste caso, se considera igual à herdabilidade; a variânc ia fenotípica permanente entre plantas (variância genotípica mais a variância ambiental pe rmanente de uma colheita para a outra); a variância de ambiente temporário (variância ambiental de cada safra); a variância fenotípica individual; a repetibilidade $\mathrm{m}$ édia de $m$ colheitas ou medidas repetidas; a acurácia da seleção baseada na média de $\mathrm{m}$ colheitas ou medidas repetidas e o ganho de seleção para produtividade em litros por planta. 


\section{RESULTADOS E DISCUSSÕES}

A Tabela 1 mostra as produtividades dos genótipos e m cada um dos anos avaliados, suas médias, coeficientes de variação de produtividade, ciclo em dias corridos do retorno da irrigação até o ponto de cereja e classe de ciclo.

Tabela 1 - Produtividade, em litros por planta, por três safras consecutivas, ciclo em dias do florescimento ao estágio de cereja, classificação por ciclo (C), médias de produtividade e coeficientes de variação da produti vidade de 85 genótipos (Gen) de C. canephora em cultivo irrigado no Cerrado. Planaltina, DF, 2016.

\begin{tabular}{|c|c|c|c|c|c|c|c|c|c|c|c|c|c|c|c|}
\hline Gen & 2012 & 2013 & 2014 & Dias & $\mathrm{C}$ & Média & CV\% & Gen & 2012 & 2013 & 2014 & Dias & $\mathrm{C}$ & Média & CV\% \\
\hline 5 & 8 & 11,5 & 12 & 263 & $\bar{P}$ & 10,50 & 16,9 & 121 & 8 & 13 & 10 & 263 & $\mathrm{P}$ & 10,33 & 19,9 \\
\hline 6 & 10 & 11 & 16 & 270 & $\mathrm{P}$ & 12,33 & 21,3 & 122 & 10 & 7 & 7 & 263 & $\mathrm{P}$ & 8,00 & 17,7 \\
\hline 7 & 11 & 8,5 & 8 & 263 & $\mathrm{P}$ & 9,17 & 14,3 & 132 & 13 & 8 & 14 & 270 & $\mathrm{P}$ & 11,67 & 22,5 \\
\hline 8 & 15 & 10 & 12 & 270 & $\mathrm{P}$ & 12,33 & 16,7 & 135 & 14 & 19,5 & 11 & 270 & $\mathrm{P}$ & 14,83 & 23,7 \\
\hline 14 & 12 & 15 & 9 & 270 & $\mathrm{P}$ & 12,00 & 20,4 & 140 & 10 & 10 & 9 & 263 & $\mathrm{P}$ & 9,67 & 4,9 \\
\hline 16 & 12 & 18,5 & 11 & 270 & $\mathrm{P}$ & 13,83 & 24,0 & 144 & 13 & 10 & 7 & 252 & $\mathrm{SP}$ & 10,00 & 24,5 \\
\hline 17 & 7 & 10 & 10 & 270 & $\mathrm{P}$ & 9,00 & 15,7 & 145 & 13 & 12 & 16 & 270 & $\mathrm{P}$ & 13,67 & 12,4 \\
\hline 18 & 7 & 8 & 10 & 263 & $\mathrm{P}$ & 8,33 & 15,0 & 146 & 9 & 9 & 13 & 270 & $\mathrm{P}$ & 10,33 & 18,2 \\
\hline 24 & 10 & 8 & 11 & 270 & $\mathrm{P}$ & 9,67 & 12,9 & 147 & 14 & 10 & 12 & 263 & $\mathrm{P}$ & 12,00 & 13,6 \\
\hline 27 & 12 & 10 & 17 & 270 & M & 13,00 & 22,6 & 150 & 14 & 12 & 8 & 263 & $\mathrm{P}$ & 11,33 & 22,0 \\
\hline 28 & 17 & 14 & 10 & 263 & $\mathrm{P}$ & 13,67 & 21,0 & 154 & 8 & 8 & 11 & 277 & M & 9,00 & 15,7 \\
\hline 32 & 7 & 7 & 11 & 252 & SP & 8,33 & 22,6 & 164 & 7 & 12 & 8 & 270 & $\mathrm{P}$ & 9,00 & 24,0 \\
\hline 40 & 13 & 20 & 15 & 263 & $\mathrm{P}$ & 16,00 & 18,4 & 165 & 13 & 11 & 12 & 263 & $\mathrm{P}$ & 12,00 & 6,8 \\
\hline 44 & 14 & 17 & 9 & 279 & $\mathrm{M}$ & 13,33 & 24,7 & 168 & 8 & 7,5 & 7 & 277 & $\mathrm{M}$ & 7,50 & 5,4 \\
\hline 46 & 10 & 10 & 15 & 270 & $\mathrm{P}$ & 11,67 & 20,2 & 169 & 7 & 9,5 & 8 & 263 & $\mathrm{P}$ & 8,17 & 12,6 \\
\hline 49 & 11 & 13 & 15 & 279 & $\mathrm{M}$ & 13,00 & 12,6 & 171 & 12 & 11,5 & 14 & 263 & $\mathrm{P}$ & 12,50 & 8,6 \\
\hline 50 & 7 & 12 & 9 & 279 & $\mathrm{M}$ & 9,33 & 22,0 & 176 & 12 & 13 & 12 & 263 & $\mathrm{P}$ & 12,33 & 3,8 \\
\hline 54 & 14 & 10,5 & 15,5 & 279 & $\mathrm{M}$ & 13,33 & 15,7 & 178 & 8 & 8 & 13 & 277 & M & 9,67 & 24,4 \\
\hline 60 & 13 & 9 & 13 & 263 & $\mathrm{P}$ & 11,67 & 16,2 & 181 & 8 & 11 & 12 & 263 & $\mathrm{P}$ & 10,33 & 16,4 \\
\hline 62 & 13 & 14 & 10 & 263 & $\mathrm{P}$ & 12,33 & 13,8 & 183 & 8 & 9 & 10 & 279 & M & 9,00 & 9,1 \\
\hline 65 & 10 & 9 & 7 & 263 & $\mathrm{P}$ & 8,67 & 14,4 & 184 & 9 & 7,5 & 9 & 263 & $\mathrm{P}$ & 8,50 & 8,3 \\
\hline 68 & 7 & 11 & 7 & 263 & $\mathrm{P}$ & 8,33 & 22,6 & 190 & 9 & 11,5 & 8 & 277 & M & 9,50 & 15,5 \\
\hline 73 & 8 & 12 & 11 & 270 & $\mathrm{P}$ & 10,33 & 16,4 & 191 & 7 & 7,5 & 9 & 277 & M & 7,83 & 10,8 \\
\hline 74 & 11 & 13,5 & 19 & 284 & ST & 14,50 & 23,0 & 193 & 12 & 11 & 10 & 263 & $\mathrm{P}$ & 11,00 & 7,4 \\
\hline 78 & 11 & 10 & 10 & 279 & $\mathrm{M}$ & 10,33 & 4,6 & 194 & 16 & 10 & 11 & 279 & M & 12,33 & 21,3 \\
\hline 80 & 7 & 11 & 13 & 270 & $\mathrm{P}$ & 10,33 & 24,1 & 202 & 8 & 9 & 8 & 279 & M & 8,33 & 5,7 \\
\hline 82 & 20 & 15 & 18 & 263 & $\mathrm{P}$ & 17,67 & 11,6 & 205 & 12 & 9 & 13 & 263 & $\mathrm{P}$ & 11,33 & 15,0 \\
\hline 83 & 13 & 13 & 19 & 279 & $\mathrm{M}$ & 15,00 & 18,9 & 206 & 13 & 10 & 10 & 263 & $\mathrm{P}$ & 11,00 & 12,9 \\
\hline 84 & 12 & 8 & 10 & 263 & $\mathrm{P}$ & 10,00 & 16,3 & 208 & 10 & 8 & 10 & 279 & M & 9,33 & 10,1 \\
\hline 88 & 8 & 11 & 7 & 263 & $\mathrm{P}$ & 8,67 & 19,6 & 209 & 11 & 10 & 7 & 263 & $\mathrm{P}$ & 9,33 & 18,2 \\
\hline 89 & 8 & 13,5 & 9,5 & 263 & $\mathrm{P}$ & 10,33 & 22,5 & 213 & 14 & 9,5 & 8 & 263 & $\mathrm{P}$ & 10,50 & 24,3 \\
\hline 90 & 13 & 9 & 13 & 263 & $\mathrm{P}$ & 11,67 & 16,2 & 216 & 8 & 9 & 12 & 279 & M & 9,67 & 17,6 \\
\hline 94 & 17 & 15 & 11 & 279 & M & 14,33 & 17,4 & 218 & 13 & 12 & 18 & 263 & $\mathrm{P}$ & 14,33 & 18,3 \\
\hline 96 & 11 & 9 & 11 & 270 & $\mathrm{P}$ & 10,33 & 9,1 & 219 & 14 & 8 & 12 & 263 & $\mathrm{P}$ & 11,33 & 22,0 \\
\hline 98 & 10 & 8 & 12 & 270 & $\mathrm{P}$ & 10,00 & 16,3 & 220 & 11 & 10 & 15 & 279 & M & 12,00 & 18,0 \\
\hline
\end{tabular}




\begin{tabular}{|c|c|c|c|c|c|c|c|c|c|c|c|c|c|c|c|}
\hline 100 & 14 & 10,5 & 17 & 270 & $\mathrm{P}$ & 13,83 & 19,2 & 221 & 13 & 7,5 & 10 & 279 & $\mathrm{M}$ & 10,17 & 22,1 \\
\hline 108 & 10 & 10,5 & 10 & 263 & $\mathrm{P}$ & 10,17 & 2,3 & 225 & 9 & 7,5 & 8 & 279 & M & 8,17 & 7,6 \\
\hline 109 & 11 & 7 & 7 & 263 & $\mathrm{P}$ & 8,33 & 22,6 & 226 & 12 & 9 & 8 & 279 & $\mathrm{M}$ & 9,67 & 17,6 \\
\hline 110 & 13 & 10 & 12 & 263 & $\mathrm{P}$ & 11,67 & 10,7 & 229 & 11 & 8,5 & 8 & 270 & $\mathrm{P}$ & 9,17 & 14,3 \\
\hline 111 & 9 & 10 & 9 & 263 & $\mathrm{P}$ & 9,33 & 5,1 & 231 & 10 & 7 & 10 & 270 & $\mathrm{P}$ & 9,00 & 15,7 \\
\hline 112 & 12 & 8 & 8 & 263 & $\mathrm{P}$ & 9,33 & 20,2 & 236 & 7 & 8 & 12 & 263 & $\mathrm{P}$ & 9,00 & 24,0 \\
\hline 114 & 12 & 9 & 15 & 270 & $\mathrm{P}$ & 12,00 & 20,4 & 238 & 7 & 7 & 7 & 263 & $\mathrm{P}$ & 7,00 & 0,0 \\
\hline 118 & 10 & 7 & 10 & 263 & $\mathrm{P}$ & 9,00 & 15,7 & Média & 10,88 & 10,41 & 11,1 & 268,6 & - & 10,79 & 16,4 \\
\hline
\end{tabular}

Classes de ciclo: $S P=$ Semi Precoce $; P=$ Precoce $; M=$ Médio $; S T=$ Semi Tardio.

As maiores produtividades em cada uma das safras foram obtidas pelos genótipos 82 (20 L), 40 (20 L) e 74 (19 L) nas safr as de 2012, 2013 e 2014, respectivamente. A média de produtividade geral foide 10,83 L por safra, enquanto que a média, em dias, para atingir o estágio de cerejafoi de 268,6. Desvio padrão médio de produtividade ficou em $1,82 \%$, enquanto que o coeficiente de variação dos valores de produtividade ao longo dos três anos ficou em 16,83\%.

Os genótipos de maiores médias de produtividade ao longo das três safras foram o 82 e o 40, com médias de 17,67 L e 16,0 L por safra, respectivamente. A principal diferença entre os dois se deu pelo fato de o genótipo 82 teve produção mais estável, com variação, ao longo dos 3 anos, inferior a 12\%. Este fator, considerando a busca por materiais de baixa bienalidade, pode ser de grande valor. Além disto, o genótipo 82 foi classificado como precoce, com cicl o de 263 dias entre o retorno da irrigação e o estádio de cereja, enquanto que o genótipo 40 levou 279 dias. Do ponto de vista da estabilidade de produção, alguns genótipos tiveram destaque, com baixíssima variação.

Os resultados obtidos para a análise de repetibilidade em cada uma das situações testadas constam na Tabela 2. 
Tabela 2 - Valores de parâmetros genéticos obtidos a partir da análise de repetibilidade de C. Canephora em três colheitas. Planaltina, DF, 2016.

\begin{tabular}{cc}
\hline $\begin{array}{c}\text { Parâmetro } \\
\text { Genético }\end{array}$ & Valor \\
\hline $\boldsymbol{V} \boldsymbol{f p}$ & 2,71 \\
$\boldsymbol{V e t}$ & 5,55 \\
$\boldsymbol{V} \boldsymbol{f}$ & 8,25 \\
$\boldsymbol{r}$ & $0,3279+-0,01014$ \\
$\boldsymbol{r m}$ & 0,59 \\
Acm & 0,77 \\
Média Geral & 10,78 \\
\hline
\end{tabular}

Vfp: Variância fenotípica permanente entre plantas; Vet: Variância de ambiente temporário; Vf: variância fenotípica individual; $r=h^{2}$ : repetibilidade individual; rm: repetibilidade média; Acm: Acurácia média da seleção baseada na média de m colheitas.

A variância fenotípica permanente entre plantas, ou seja, aquela que desconsidera os efeitos ambientais temporários, representou $30 \%$ da variância fenotípica total. Este fator evidencia menor influência de variações temporárias no comportamento dos materiais, ou maior adaptação às condições locais. A repetibilidade individual, que neste caso pode ser considerada equivalente à herdabilidade, atingiu valor próximo de 0,30 (Tabel a 2) De acordo com Resende (2002), valores de repetibilidade entre 0,30 e 0,60 são considerados médios. Porém, considerando o baixo número de safras (apenas 3) e que se trata de uma espécie perene, estes valores certamente serão mais consist entes com um maior número de repetições, ou conforme avançarem os ciclos de sele ção e avaliação dos materiais. Além disto, quando se considera a repetibilidade média $(\mathrm{rm})$, o valor sobe para 55,5\%, um valor bem próximo, segundo o mesmo autor, dos valores considerados altos para este parâmetro. Outro fator a ser ponder ado é que a produtividade é altamente influenciada pelo ambiente.

A repetibilidade pode ser interpretada como o valor máximo da herdabilidade no sentido amplo, pois expressa a variância genotípica adicionada aos efeitos permanentes de ambiente. Neste sentido, os valores de repetibilidade obtidos neste estudo se aproximam bastante daqueles encontrados por Ramalho et al.(2011), trabalhando com o café Conilon no estado de Rondônia. Também Mistro et al.(2008) observaram valores para o coeficiente de repetibilidade entre 0,26 e 0,63 , semelhantes aos aqui demonstrados. Cabe ressaltar, no entanto, que estes autores usaram em seus ensaios seis e nove repetições, resp ectivamente, sempre com duas 
plantas por parcela, enquanto aqui utilizou-se apenas uma repetição, com uma planta por parcela, e colheita por três anos consecutivos .

Na tabela 3 são apresentados os valores de acuráciaem relação ao número de medidas.

Tabela 3 - Acurácia de seleção em função do número de medições repetidas para produtividade em Café Conilon. Planaltina, DF, 2016.

\begin{tabular}{cc}
\hline $\mathbf{m}$ & Acurácia \\
\hline $\mathbf{1}$ & 0,573 \\
$\mathbf{2}$ & 0,703 \\
$\mathbf{3}$ & 0,771 \\
$\mathbf{4}$ & 0,813 \\
$\mathbf{5}$ & 0,843 \\
$\mathbf{6}$ & 0,863 \\
$\mathbf{7}$ & 0,879 \\
$\mathbf{8}$ & 0,892 \\
$\mathbf{9}$ & 0,902 \\
$\mathbf{1 0}$ & 0,911 \\
\hline
\end{tabular}

$m=$ número de medições ou repetições.

Fonseca et al. (2004) citaram que quatro colheitas sucessivas seriam suficientes para a seleção de genótipos de café rob usta para produtividade com uma acurácia de $80 \%$, valor considerado bastante satisfatório também por Resende (2002), para quem a acurácia seletiva entre 0,7 e 0,9 é considerada alta. Neste ensaio, a acurácia obtida em três colheitas foi de aproximad mente $75 \%$, e estimada em $79 \%$ com quatro colheitas. A acurácia seletiva é fortemente influenciada pela herdabilidade e da repetibilidade do caráter, da quantidade e da qualidade de informações e dos procedimentos utilizados na predi ção dos valores genéticos. Como é uma medida que está associada à precisão na seleção, ou seja, refere-se à correlação entre valores genéticos preditos e valores genéticos verdadeiros dos indivíduos, e quanto maior a acurácia na avaliação de um indivíduo, maior é a confiança na avaliação e no valor genético predito do indivíduo. A acurácia também é um dos principais elementos do progresso genético, em que o melhorista pode alterar, visando a maximizar o ganho genético (Sturion; Resende, 2005).

Segundo Resende \& Duarte (2007), a avaliação de gen ótipos deve considerar não apenas a perspectiva estatística, mas também a óptica genética, observando-se a acurácia seletiva, uma vez que este parâmetro considera as proporções entre as 
variações de natureza genética e residual, associad as à característica em avaliação, além da amplitude da variação residual. Henderson (1984), no contexto da avaliação genotípica, classifica a acurácia seletiva como o parâmetro estatístico mais importante. Desse modo, o uso desta estatística associada contribui para que o melhorista maximize seus ganhos no processo de seleção de caracteres qu antitativos (Amabile, 2013).

Trabalhando com o coeficiente de repetibilidade na cultura do pêssego, Della Bruna et al. (2012) obtiveram para a característica produção de frutos por planta uma variação do coeficiente de repetibilidad e entre 0,22 e 0,29, com estimativas de acurácia $(A c m)$ entre 60,0 e 75,0\%. A repetibilidade $(0,30)$ e a acurácia $(75 \%)$ obtidas neste ensaio estão, portanto, dentro do observado para outras plantas perenes. Já Júnior et al.(2013), trabalhando com a cultura do limoeiro, obteve coeficientes de repetibilidade individual (r) em torno de 0,1 , atingindo os 0,35 na média de 5 safras. A acurácia obtida por estes autores foi de $58 \%$ em uma e $84 \%$ em cinco safras, valores aproximados aos demonstrados aqui, de $54,2 \%$ e $82,1 \%$ em uma e cinco safras, respectivamente. Percebe-se, portanto, que o aumento no número de medições permite o aumento na acurácia da seleção. Porém, estes aumentos são menores a cada ano, tornando-se menos significativos, sendo possível inferir que a partir da quinta colheita os aumentos na acurácia não justificariam o aporte de recursos necessário.

Os valores fenotípicos dos indivíduos, bem como o ganho de seleção inerente a cada um deles, estão demonstrados na Tab ela 4. 
Tabela 4 - Classificação, valor fenotípico (fp), ganho de sele ção (em litros por planta) e Nova Média da população de 85 genótipos de C. canephora em cultivo irrigado no Cerrado. Planaltina, DF, 2016.

\begin{tabular}{|c|c|c|c|c|c|c|c|c|c|c|c|}
\hline Ordem & Gen & $\mathrm{fp}$ & $\mathrm{U}+\mathrm{fp}$ & Ganho & $\begin{array}{c}\text { Nova } \\
\text { Média }\end{array}$ & Ordem & Gen & $\mathrm{fp}$ & $\mathrm{U}+\mathrm{fp}$ & Ganho & $\begin{array}{l}\text { Nova } \\
\text { Média }\end{array}$ \\
\hline 1 & 82 & 4,088 & 14,874 & 4,088 & 14,874 & 44 & 121 & $-0,269$ & 10,517 & 0,962 & 11,748 \\
\hline 2 & 40 & 3,097 & 13,884 & 3,593 & 14,379 & 45 & 146 & $-0,269$ & 10,517 & 0,935 & 11,721 \\
\hline 3 & 83 & 2,503 & 13,290 & 3,230 & 14,016 & 46 & 181 & $-0,269$ & 10,517 & 0,908 & 11,695 \\
\hline 4 & 135 & 2,404 & 13,191 & 3,023 & 13,810 & 47 & 108 & $-0,368$ & 10,418 & 0,881 & 11,668 \\
\hline 5 & 74 & 2,206 & 12,993 & 2,860 & 13,646 & 48 & 221 & $-0,368$ & 10,418 & 0,855 & 11,641 \\
\hline 6 & 94 & 2,107 & 12,894 & 2,734 & 13,521 & 49 & 84 & $-0,467$ & 10,319 & 0,828 & 11,614 \\
\hline 7 & 218 & 2,107 & 12,894 & 2,645 & 13,431 & 50 & 98 & $-0,467$ & 10,319 & 0,802 & 11,589 \\
\hline 8 & 16 & 1,810 & 12,597 & 2,541 & 13,327 & 51 & 144 & $-0,467$ & 10,319 & 0,777 & 11,564 \\
\hline 9 & 100 & 1,810 & 12,597 & 2,459 & 13,246 & 52 & 24 & $-0,665$ & 10,121 & 0,750 & 11,536 \\
\hline 10 & 28 & 1,711 & 12,498 & 2,385 & 13,171 & 53 & 140 & $-0,665$ & 10,121 & 0,723 & 11,509 \\
\hline 11 & 145 & 1,711 & 12,498 & 2,323 & 13,110 & 54 & 178 & $-0,665$ & 10,121 & 0,697 & 11,484 \\
\hline 12 & 44 & 1,513 & 12,300 & 2,256 & 13,042 & 55 & 216 & $-0,665$ & 10,121 & 0,673 & 11,459 \\
\hline 13 & 54 & 1,513 & 12,300 & 2,199 & 12,985 & 56 & 226 & $-0,665$ & 10,121 & 0,649 & 11,435 \\
\hline 14 & 27 & 1,315 & 12,101 & 2,136 & 12,922 & 57 & 190 & $-0,764$ & 10,022 & 0,624 & 11,410 \\
\hline 15 & 49 & 1,315 & 12,101 & 2,081 & 12,867 & 58 & 50 & $-0,863$ & 9,923 & 0,598 & 11,384 \\
\hline 16 & 171 & 1,018 & 11,804 & 2,015 & 12,801 & 59 & 111 & $-0,863$ & 9,923 & 0,573 & 11,360 \\
\hline 17 & 6 & 0,919 & 11,705 & 1,950 & 12,736 & 60 & 112 & $-0,863$ & 9,923 & 0,549 & 11,336 \\
\hline 18 & 8 & 0,919 & 11,705 & 1,893 & 12,6 & 61 & 208 & $-0,863$ & 9,923 & 0,526 & 11,313 \\
\hline 19 & 62 & 0,919 & 11,705 & 1,842 & 12,628 & 62 & 209 & $-0,863$ & 9,923 & 0,504 & 11,290 \\
\hline 20 & 176 & 0,919 & 11,705 & 1,795 & 12,582 & 63 & 7 & $-0,962$ & 9,824 & 0,481 & 11,267 \\
\hline 21 & 194 & 0,919 & 11,705 & 1,754 & 12,540 & 64 & 229 & $-0,962$ & 9,824 & 0,458 & 11,244 \\
\hline 22 & 14 & 0,721 & 11,507 & 1,707 & 12,493 & 65 & 17 & $-1,061$ & 9,725 & 0,435 & 11,221 \\
\hline 23 & 114 & 0,721 & 11,507 & 1,664 & 12,450 & 66 & 118 & $-1,061$ & 9,725 & 0,412 & 11,198 \\
\hline 24 & 147 & 0,721 & 11,507 & 1,625 & 12,411 & 67 & 154 & $-1,061$ & 9,725 & 0,390 & 11,176 \\
\hline 25 & 165 & 0,721 & 11,507 & 1,588 & 12,375 & 68 & 164 & $-1,061$ & 9,725 & 0,369 & 11,155 \\
\hline 26 & 220 & 0,721 & 11,507 & 1,555 & 12,341 & 69 & 183 & $-1,061$ & 9,725 & 0,348 & 11,134 \\
\hline 27 & 46 & 0,523 & 11,309 & 1,517 & 12,303 & 70 & 231 & $-1,061$ & 9,725 & 0,328 & 11,114 \\
\hline 28 & 60 & 0,523 & 11,309 & 1,481 & 12,268 & 71 & 236 & $-1,061$ & 9,725 & 0,308 & 11,095 \\
\hline 29 & 90 & 0,523 & 11,309 & 1,448 & 12,235 & 72 & 65 & $-1,259$ & 9,527 & 0,287 & 11,073 \\
\hline 30 & 110 & 0,523 & 11,309 & 1,418 & 12,204 & 73 & 88 & $-1,259$ & 9,527 & 0,265 & 11,052 \\
\hline 31 & 132 & 0,523 & 11,309 & 1,389 & 12,175 & 74 & 184 & $-1,358$ & 9,428 & 0,243 & 11,030 \\
\hline 32 & 150 & 0,325 & 11,111 & 1,355 & 12,142 & 75 & 18 & $-1,457$ & 9,329 & 0,221 & 11,007 \\
\hline 33 & 205 & 0,325 & 11,111 & 1,324 & 12,110 & 76 & 32 & $-1,457$ & 9,329 & 0,199 & 10,985 \\
\hline 34 & 219 & 0,325 & 11,111 & 1,295 & 12,081 & 77 & 68 & $-1,457$ & 9,329 & 0,177 & 10,963 \\
\hline 35 & 193 & 0,127 & 10,913 & 1,261 & 12,048 & 78 & 109 & $-1,457$ & 9,329 & 0,156 & 10,942 \\
\hline 36 & 206 & 0,127 & 10,913 & 1,230 & 12,016 & 79 & 202 & $-1,457$ & 9,329 & 0,136 & 10,922 \\
\hline 37 & 5 & $-0,170$ & 10,616 & 1,192 & 11,978 & 80 & 169 & $-1,556$ & 9,230 & 0,115 & 10,901 \\
\hline 38 & 213 & $-0,170$ & 10,616 & 1,156 & 11,943 & 81 & 225 & $-1,556$ & 9,230 & 0,094 & 10,880 \\
\hline 39 & 73 & $-0,269$ & 10,517 & 1,120 & 11,906 & 82 & 122 & $-1,655$ & 9,131 & 0,073 & 10,859 \\
\hline 40 & 78 & $-0,269$ & 10,517 & 1,085 & 11,871 & 83 & 191 & $-1,754$ & 9,032 & 0,051 & 10,837 \\
\hline 41 & 80 & $-0,269$ & 10,517 & 1,052 & 11,838 & 84 & 168 & $-1,952$ & 8,834 & 0,027 & 10,813 \\
\hline 42 & 89 & $-0,269$ & 10,517 & 1,021 & 11,807 & 85 & 238 & $-2,249$ & 8,537 & 0,000 & 10,786 \\
\hline
\end{tabular}


Notou-se que a variabilidade da população permite a obtenção de ganhos expressivos a partir da seleção de genótipos superi ores. A predição do valor fenotípico permanente é extremamente relevante por permitir selecionar indivíduos que serão cultivados em ambiente semelhante ao que estão sendo avaliados, e dessa forma capitalizam-se os efeitos aditivos e de ambiente permanente. Além disso, é possível a seleção de genótipos para propagação veg etativa, ou seja, fora do ambiente em que foram avaliados, e dessa forma capitalizam-se os efeitos aditivos (Della Bruna et al., 2012).

A Figura 1 representa as temperaturas mínimas e médias do mês de junho de 2011 a 2014, os quatro anos/safras em que foram realizadas as avaliações de produtividade. 
Figura 1 - Temperaturas médias e mínimas do mês de junho dosanos/safras relativos ao estudo. Planaltina, DF, 2016.

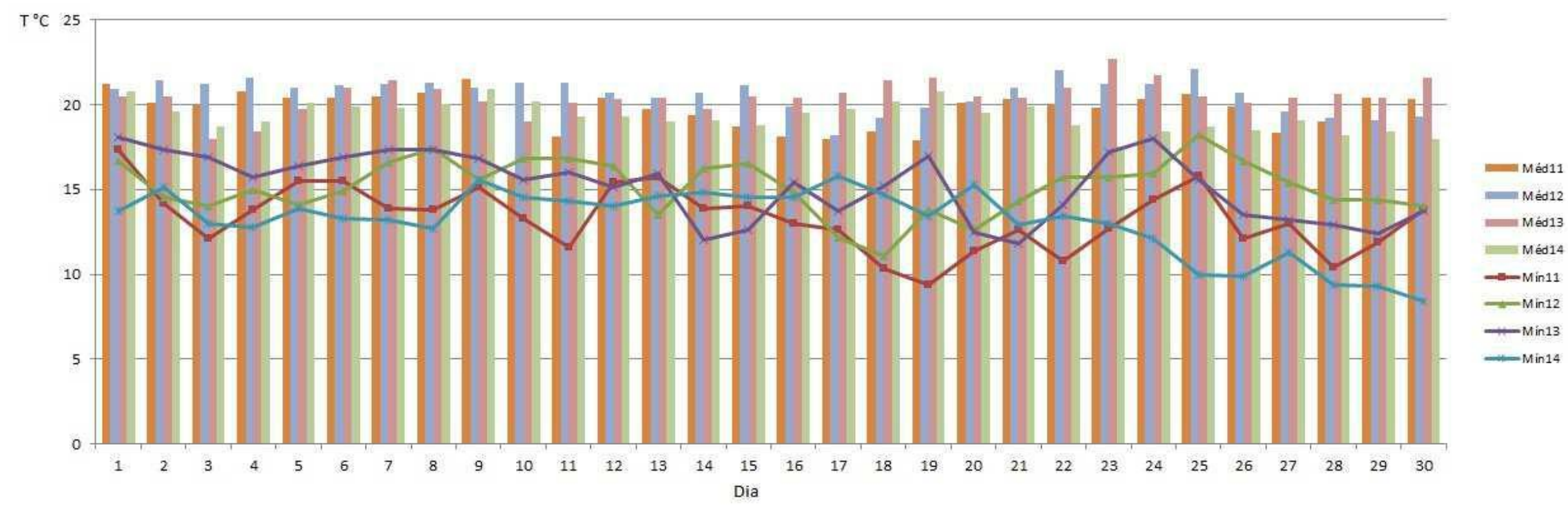


Percebe-se, pela análise do gráfico, que durante omês de junho, reconhecidamente aquele em que se verificam as menores temperaturas mínimas e médias do ar na região, houve ocorrência esporádicade temperaturas mínimas inferiores a $10^{\circ} \mathrm{C}$, e com maior frequência, inferiores a $15^{\circ} \mathrm{C}$. Porém, em nenhuma ocasião houve temperatura média abaixo de $15^{\circ} \mathrm{C}$.

Com relação à temperatura, Ramalho e colaboradores (2003) perceberam maior sensibilidade ao frio por parte de $C$. canephora em relação a $\quad$ C. arabica. Trabalhando com a cultivar Apoatã (IAC 2258), os autores eviden ciaram forte inibição da fotossíntese com a combinação de temperaturas diurn as de $15^{\circ} \mathrm{C}$ e noturnas de $10{ }^{\circ} \mathrm{C}$. DaMatta et al. (1997) relatam que, quando cultivados em altitudes elevadas, C. arabica geralmente tem melhor desempenho do que C. canephora, sendo o contrário percebido em terras quentes e de altitudes menores e que daí vem o entendimento de que esta espécie é mais vulnerável ao frio do que aquela. Porém, ao avaliarem parâmetros fotossintéticos de cultivares de ambas as espécies em condições de inverno (temperaturas diurnas de $19,4{ }^{\circ} \mathrm{C}$ e noturnas de $\left.13,9^{\circ} \mathrm{C}\right)$ e verão $\left(23,5^{\circ} \mathrm{C} / 19.9^{\circ} \mathrm{C}\right.$, respectivamente), os mesmos autores não confirmaram maior sensibilidade ao frio para C. canephora variedade Kouillou. Para eles, então, a diferença de comportamento entre as espécies em diferentes altitudes não poderia ser justificada por alterações na fotossíntese, mas possivelmente por efeitos das menores temperaturas sobre o armazenamento de fotoassimilados, as relações fonte -dreno, respiração, hormônios ou outros processos.

Partelli et al. (2009), por outro lado, perceberam diferença significativa entre as espécies, no que concerne a parâmetros de atividade fotossintética, com a tendência de maior tolerância ao frio para as variedades de $C$. arabica e menor tolerância para $C$. canephora. As temperaturas testadas por estes autores foram decréscimo de $0,5^{\circ} \mathrm{C}$ por dia de $25 / 20{ }^{\circ} \mathrm{C}$ até $13 / 8{ }^{\circ} \mathrm{C}$ (diurnas/noturnas) e um período de três dias em $13 / 4{ }^{\circ} \mathrm{C}$, com posterior fase de recuperação em $25 / 20^{\circ} \mathrm{C}$. Part elli e colaboradores (2011) citam diversos autores relatando que as baixas temperaturas limitam a distribuição geográfica do café quando as temperaturas médias mensais são nferiores a $15-16{ }^{\circ} \mathrm{C}$, o que não se notou durante o período em que este estudo foi conduzido; a fotossíntese é afetada já abaixo dos $18{ }^{\circ} \mathrm{C}$, e o frio severo tem graves conseq uências sobre o rendimento. Porém, aqueles autores deixam claro que as plantas possuem certa capacidade de aclimatação 
ao frio, com mecanismos fisiológicos como proteção contra estresse oxidativo e manutenção de alta estabilidade de membrana celular .

Cabe ressaltar, portanto, que as temperaturas testadas por Ramalho et al. (2003), DaMatta et al. (1997), e Partelli e colaboradores (2009; 2011) não foram comuns nos períodos de inverno em que se deu este ensaio. Considerando, ainda, a região do Cerrado Baiano, atual fronteira de expans ão da cultura do café, tais valores também são pouco frequentes. Observa-se, pelos resultados obtidos de produtividade, que a condição climática existente na região do estudo não parece ter afetado o desempenho de todas das plantas a ponto de reduzir a produtividade a níveis muito baixos. 


\section{CONCLUSÕES}

- Há variabilidade genética dentro da população estudada em relação à produtividade e ao ciclo de maturação.

- Existem genótipos promissores para cultivo irrig ado no Brasil Central dentro da população estudada, podendo estes materia is serem indicados para cruzamentos e/ou o desenvolvimento de variedades clonais e sintéticas.

- Os resultados obtidos para repetibilidade média e acurácia favorecem a seleção de genótipos com base no fenótipo.

- A repetibilidade pode ser usada como um parâmetro adequado para o melhoramento do café Conilon. 


\section{REFERÊNCIAS BIBLIOGRÁFICAS}

AMABILE, R. F. Caracterização molecular, morfoagronômica e de qual idade de grãos de genótipos elite de cevada irrigada no Cerr ado. 2013, 220 f. Tese (Doutorado). Universidade de Brasília, Brasília, 2013.

CARNEIRO, F. A.; RÊGO, E. C. S.; COSTA, T. S.; OLIV EIRA, S. A.; DUARTE, K. E.; ROCHA, O. C.; RODRIGUES, G. R.; CARVALHO, M. A. F.; MARRACCINI, P.; GRATTAPAGLIA, D.; BARTHOLO, G. F.; GUERRA, A. F.; ANDRADE, A. C. Avaliação fenotípica de uma populaç ão de Coffea canephora var. Conilon cultivada em altitude elevada, visando um programa de seleção genômica (SGA) em cafeeiro. In: SIMPÓSIO DE PESQUIS A DOS CAFÉS DO BRASIL, 8., 2013, Salvador. Resumos Expandidos.. Brasília. Embrapa Café, 2013. CRUZ, C. D.; REGAZZI, A. J. Modelos biométricos aplicados ao melhoramento genético. 2. ed. Viçosa: UFV, 2001. 390 p.

DaMATTA, F. M.; MAESTRI, M.; MOSQUIM, P. R.; BARROS, B.S. Photosynthesis in coffee (Coffea arabica and C. canephora) as affected by winter and summer conditions. Plant Science. v. 128, p. 43-50. 1997.

DELLA BRUNA, E; MORETO, L. M; DALBÓ, M. A. Uso do c oeficiente de repetibilidade na seleção de clones de pessegueiro para o litoral sul de Santa Catarina. Revista Brasileira de Fruticultura. Jaboticabal. v. 34, n. 1, p. 206215. mar. 2012.

FALCÃO, A. J. S.; MARTINS, E. N.; COSTA, C. N.; MAZ UCHELI, J. Efeitos do número de animais na matriz de parentesco sobre as estimativas de componentes da variância para produção de leite usando os métodos de máxima verossimilhança restrita e bayesiano. Revista Brasileira de Zootecnia, v. 38, n. 8 , p. 1478-1487, 2009.

FERNANDES, A. L. T.; PARTELLI, F. L.; BONOMO, R.; GOLYNSKI, A. A moderna cafeicultura dos Cerrados brasileiros. Pesquisa Agropecuária Tropical, v. 42, n 2, p. 231-240, 2012. 
FERRÃO, R. G. Biometria aplicada ao melhoramento genético do caféconilon. Viçosa, MG: DFT/UFV, 2004. 256 f. Tese (Doutorado e m Genética e Melhoramento) - Universidade Federal de Viçosa, 2004.

FERRÃO, R. G.; FONSECA, A. F. A.; FERRÃO, M. A. G.; BRAGANÇA, S. M.; FERRÃO, L. M. V. EMCAPER 8151 - Robusta Tropical: v ariedade melhorada de café conilon de propagação por sementes para o estado do Espírito Santo. SIMPÓSIO BRASILEIRO DE PESQUISA DOS CAFÉS DO BRASIL ， 1.2000. Resumos Expandidos.. Poços de Caldas, MG. Embrapa Café, 2000.

FONSECA, A. F. A.; SEDIYAMA, T.; CRUZ, C. D.; SAKAIYAMA, N. S.; FERRÃO, M. A. G.; FERRÃO, R. G.; BRAGANÇA, S. M. Di vergência genética em café conilon.Pesquisa Agropecuária Brasileira, Brasília, v. 41, n. 4, p. 599-605, abr. 2006.

FONSECA A. F. A.; SEDIYAMA, T.; CRUZ, C. D.; SAKIYAMA, N. S.; FERRÃO, R. G.; FERRÃO, M. A. G.; BRAGANÇA, S. M. Repeatabil ity and number of harvests required for selection in robusta coffee. Crop Breeding and Applied Biotechnology, v. 4, n.3, p. 325-329. 2004.

HENDERSON, C. R. Applications of linear models in animal breeding. Guelph: University of Guelph, 1984. 462 p.

JUNIOR, J. P.; BLUMER, S.; RESENDE, M. D. V. Avaliação genética de seleções e híbridos de limões cravo, volkameriano e rugoso com o porta-enxertos para laranjeiras valência na presença da morte súbita dos citros. Revista Brasileira de Fruticultura, Jaboticabal, SP, v. 35, n. 1, p. 199-209. mar. 2013.

LOPES, P.S.; MARTINS, E.N.; SILVA, M.A.; REGAZZI, A.J. Estimação de componentes de variância. Viçosa: Imprensa Universi tária, 1998. 61p MISTRO, J. C.; FAZUOLI, L. C.; GUERREIRO FILHO, O.; SILVAROLLA, M. B.; TOMA-BRAGHINI, M. Determination of the number of years in Arabic coffee progenies selection through repeatability. Crop breeding and applied biotechnology. v. 8, p. 79-84, 2008. 
PARTELLI, F. L; BATISTA-SANTOS, P.; SCOTTI-CAMPOS, P.; PAIS, I. P.; QUARTIN, V. L.; VIEIRA, H. D.; RAMALHO, J. C. Characterization of the main lipid components of chloroplast membranes and cold induced changes in Coffea spp.

Environmental and Experimental Botany, v. 74, n. 1, p. 194-204, 2011.

PARTELLI, F. L.; PAIS, I.; VIEIRA, H. D.; VIANA, A. P.; RAMALHO, J. C. Alterações da composição de açúcares em genótipos d e cafeeiro (Coffea sp.) submetidos a baixas temperaturas positivas. In: SIMPÓSIO DE PESQUISA DOS CAFÉS DO BRASIL, VI, 2009. Vitória. Resumos Expandidos.. Brasília, Embrapa Café, 2011.

PATTERSON, H.D.; THOMPSON, R. Recovery of inter-block information when block sizes are unequal. Biometrika, London, v.58, p.545-554, 1971.

PEZZOPANE, J. R. M.; PEDRO JÚNIOR, M. J.; THOMAZIEL LO, R. A.; CAMARGO, M. B. P. Escala para avaliação de estádios fenológicos do cafeeiro arábica.Bragantia, Campinas, v. 62, n. 3, p. 499-505, 2003.

RAMALHO, A. R.; ROCHA, R. B.; SOUZA, F. F.; TEIXEIRA, A. L.; VENEZIANO, W. Progresso genético com a seleção de clones de conilon no estado de Rondônia. In: SIMPÓSIO DE PESQUISA DOS CAFÉS DO BRASIL, 7, 2011. Araxá.Resumos Expandidos.. Brasília, Embrapa Café, 2011.

RAMALHO, J. C.; QUARTIN, V. L.; LEITÃO, E.; CAMPOS, P. S.; CARELLI, M. L. C.; FAHL, J. I.; NUNES, M. A. Cold acclimation ability and photosynthesis among species of the tropical Coffea genus. Plant Biology, v. 5. p. 631-641, 2003.

RESENDE, M. D. V. de; DUARTE, J. B. Precisão e cont role de qualidade em experimentos de avaliação de cultivares. Pesquisa Agropecuária Tropical, v. 37, n. 3, p. 182-194, 2007.

RESENDE, M. D. V. Genética biométrica e estatística no melhoramento ed plantas perenes. Brasília: EMBRAPA Informação Tecnológica, 2002, 975 p.

RESENDE, M. D. V. Selegen-Reml/Blup: Sistema Estatístico e Seleção Genética Computadorizada via Modelos Lineares Mistos. 1. ed. Colombo: Embrapa Florestas, 2007. 360 p. 
ROCHA, O. C.; GUERRA, A. F.; RODRIGUES, G. C.; SANZONOWICZ.;

SILVA, F. A. M.; RIBEIRO, L. F.; TOLEDO, P. M. R. Programa para

monitoramento de irrigação do cafeeiro no Cerrado. In: VIII Simpósio brasileiro de pesquisa em cafeicultura irrigada, 2006, Araguari. VIII Simpósio Brasileiro de

Pesquisa em Cafeicultura Irrigada. Viçosa: UFV, 2006. p. 61-64.

SERA, G. H.; SERA, T.; PEREIRA, C. T. M.; CARDUCCI, F. C.; MARIUCCI

JÚNIOR, V.; COSTA, K. C.; ANDREAZI, E.; CARVALHO, F . G.; ROCHA, L.

M.; MACHADO, P.; SHIGUEOKA, L. H.; BROCCO, L. A. F. Identificação de

progênies de café arábica portadoras de genes deCoffea racemosa com ciclo de maturação de frutos precoce. In: SIMPÓSIO DE PESQUISA DOS CAFÉS DO

BRASIL, 9, 2015, Curitiba. Resumos Expandidos.. Brasília: Embrapa Café, 2015.

SILVA, F. L.; OLIVEIRA, A. C. B.; PEREIRA, A. A.; BOTELHO, C. E.;

REZENDE, . C.; CARVALHO, G. R. Repetibilidade e número de colheitas para seleção de progênies de café arábica. CONGRESSO BRASILEIRO DE MELHORAMENTO DE PLANTAS. Anais.. Vitória, ES. 2009.

STURION, J. A.; RESENDE, M. D. V. Seleção de progênies de erva-mate (Ilex paraguarensis St. Hil.) para produtividade, estabilidade e adaptabilidade temporal de massa foliar. Boletim de Pesquisa Florestal, Colombo, n. 50, p. 37-51, 2005. 


\title{
Capítulo 2
}

\section{FORÇA DE DESPRENDIMENTO DOS FRUTOS DE CAFÉ CONILON Coffea canephora Pierre ex Froehner AO LONGO DE SEU CICLO DE MATURAÇÃO EM CULTIVO IRRIGADO NO Cerrado}

\begin{abstract}
RESUMO
O presente estudo objetivou determinar a força de desprendimento e o ciclo de maturação dos frutos de genótipos de café Conilon, oriundos de cruzamentos em campo isolado da cultivar Robusta Tropical, em cinco estádios de maturação (verde, verde cana, cereja, passa e coco). O campo experimental, localizado na Embrapa Cerrados, em Planaltina, DF, foi estabelecido em 2009, com irrigação por aspersão via pivô central, no espaçamento de $3,5 \mathrm{~m} \times 1,0 \mathrm{~m}$. As medições foram re alizadas utilizando-se um dinamômetro portátil Instrutherm DD 300, amostrando seis frutos de cada lado da linha de cultivo, tomados ao acaso no terço médio das plantas. Os dados de força de desprendimento em cada estádio foram utilizados par determinar a curva de força de desprendimento de cada material, por meio de regressão logística, utilizando-se o software R. De acordo com a duração do ciclo, os ge nótipos foram divididos em precoces e médios, e foram obtidos os valores dos coeficientes da equação da curva de força de desprendimento, os quais estão relacionado s com o ponto de interceptação do eixo y $(b 0)$ e a inclinação da curva ( $b 1)$. Notou-se variação na força de desprendimento entre os materiais e ao longo do ciclo, com uma tendência de forças menores nos estádios cereja, passa e coco. Estes resultados apontam para a possibilidade alguns genótipos serem mais aptos à colheita mecanizada se letiva. O estádio de passa apresentou uma tendência a ser o mais adequado paraa colheita mecanizada, por exigir menor força para se desprender dos ramos.
\end{abstract}

PALAVRAS-CHAVE: Coffea canephora, Robusta Tropical, maturação, variabilidade, colheita mecanizada. 


\title{
DETACHMENT FORCE OF CONILON COOFEE (Coffea canephora Pierre ex Froehner) FRUITS THROUGHOUT ITS MATURATION CICLE IN IRRIGATED GROWS IN Cerrado OF DISTRITO FEDERAL
}

\begin{abstract}
This study aimed to determinate the detachment force and the maturation cycle of the fruits of Conilon coffee genotypes, originated from open field crossings of the Robusta Tropical cultivar, in five stages along the maturation cycle (green, green cane, cherry, pass and dry). The experimental field, located in Embrapa Cerrados, in Planaltina, DF, was established in 2009, sprinkled irrigated by central pivot, with 3,5 m between rows and 1,0 $\mathrm{m}$ between plants in the row. The measurements were realized using a portable dynamometer Instrutherm DD 300, and there were sampled six fruits from each side of the row, in the medium part of the plant. The data of release strength in each maturation stage were used to determinate the detachment strength curve of each genotype, by logistic regression, using the $\mathrm{R}$ software. According to the cycle duration, the genotypes were disported in early cycle and medium cycle, and were estimated the equation coefficients, which are connected to the interception point of the Y-axis $(b 0)$ and the curve inclination $(b 1)$. There were perceived variations of the release strength of the fruits between genotypes and along the maturation cycle, with a clear tendency of lower strengths on cherry, pass and dry stages. These results indicate the possibility of some genotypes be more apt to selective mechanical harvesting. The pass stage showed a tendency to be the most appropriate for mechanical harvesting, by requiring less force to break off the branches.
\end{abstract}

Index terms: Coffea canephora, Robusta Tropical, maturation, variability, breeding, mechanical harvesting. 


\section{INTRODUÇÃO}

O cultivo de Coffea canephora no Cerrado do Brasil Central passa

obrigatoriamente pela seleção de materiais adaptado s ao clima e sistema de cultivo da região. O sistema de cultivo de café arábica no Cerrado é baseado em grandes áreas e alto investimento em tecnologia, com irrigação (pri ncipalmente via pivô central) e mecanização de operações, especialmente a colheita. Oliveira e colaboradores (2007) relataram que a colheita mecanizada proporcionou uma redução de custos superior a $62 \%$ em relação à colheita manual do café.

A derriça dos frutos é o objetivo do trabalho da máquina e deve ser avaliada em diferentes estádios de maturação dos frutos, cultivares, cafeeiros e condições locais da cultura. A maior ou menor facilidade de derriça dos grãos está associada, entre outros fatores, ao estágio de maturação dos frutos. Na fase inicial de colheita, para C. arabica, quando grande parte dos grãos se encontra no estádio "verde" e "cereja", a máquina terá menor eficiência de derriça (Kashima et al., 1986).Rena et al. (1994) relataram que no café conilon os frutos são mais fortemente aderidos à planta do que os de café arábica, não caindo facilmente quando maduros, característic a que deve interferir na colheita.

De acordo com Crisosto e Nagao (1991), a força nece ssária ao desprendimento dos frutos do cafeeiro é significativamente diferente quando se considera tanto estádios de maturação quanto materiais genéticos distintos. Os mesmos autores observaram que a força necessária para retirar da planta os frutos verdes foi aproximadamente o dobro daquela aplicada para a colheita dos frutos cereja. Para Silva et al. (2013), também a força de desprendimento varia entre cultivares e de acordo com a maturação; estes autores citam esta variação como um importante fato $r$ para o gerenciamento da colheita mecanizada.

O objetivo deste trabalho foi caracterizar diferentes genótipos de C. canephora com relação à força de desprendimento dos frutos em diferentes estádios de maturação, à distância entre ramos plagiotrópicos e à altura d e plantas. 


\section{OBJETIVOS}

- Caracterizar a variabilidade fenotípica de uma população de C. canephora irrigada no Cerrado do Distrito Federal com relação à força de desprendimento de frutos.

- Caracterizar a variação de força de desprendimento dos frutos ao longo de seu ciclo de maturação. 


\section{MATERIAL E MÉTODOS}

O trabalho foi conduzido no Campo Experimental da Embrapa Cerrados, localizada em Planaltina, Distrito Federal, situada a 15³5'30" latitude S, 47² '30" longitude $\mathrm{O}$ e altitude de $1.007 \mathrm{~m}$, num solo classificado como LATOSSOLO VERMELHO Distrófico típico, argiloso. Os resultados médios de análise química do solo na profundidade de $0-20 \mathrm{~cm}$ apresentaram os seguintes resultados: 1,14 mmolc. $\mathrm{dm}^{-3}$ de $\mathrm{Al} ; 16,4$ mmolc.dm ${ }^{3}$ de $\mathrm{Ca} ; 0,63$ mmolc. $\mathrm{dm}^{3}$ de $\mathrm{K} ; 2,5$ mmolc.dm ${ }^{3}$ de $\mathrm{Mg} ; 59,6$ ppm de $\mathrm{P} ; 27,8 \mathrm{~g} / \mathrm{kg}$ de matéria orgânica e pH em água de 4,44; areia grossa $=60 \mathrm{~g} \mathrm{~kg}$ ${ }^{1}$; areia fina $=380 \mathrm{~g} \mathrm{~kg}^{-1}$; silte $=130 \mathrm{~g} \mathrm{~kg}^{-1}$ e argila $=430 \mathrm{~g} \mathrm{~kg}^{-1}$.

A área vinha sendo cultivada nos anos anteriores com culturas anuais, e o estabelecimento deste ensaio se deu em abril de 2009, com o espaçamento de $3,5 \mathrm{~m}$ entre linhas e 1,0 m entre plantas. Foram avaliados 220 genótipos de $C$. canephora oriundos de cruzamentos naturais dentro de um campo experimental da cultivar Robusta Tropical (EMCAPER 8151), da Empresa Capixaba de Pesquisa e Extensão Rural - EMCAPER (Ferrão et al., 2000). O método de irrigação utilizado foi a aspersão, e o sistema adotado foi por pivô central. O critério de manejo da irrigação fundamentou-se no monitoramento do clima, sendo que o momento de irrigação ocorria a cada cinco dias, de acordo com o Programa de Monitoramento de Irrigação do Cerrado (Rocha et al., 2008). Para uniformização da florada, a irrigação era susp ensa em primeiro de julho e retornava sempre que no mínimo $80 \%$ das gemas florais atingiam $80 \%$ do estádio E4, com data limite do retorno da água de irrigação em 4 de setembro de cada ano.

$\mathrm{Na}$ implantação do experimento foram adicionados $120 \mathrm{~g}$ de superfosfato triplo, $50 \mathrm{~g}$ de termofosfato magnesiano (Yoorin ${ }^{\circledR}$ ) e 24,5 $\mathrm{g}$ de fritted trace elements (FTE BR 12) por cova. A calagem foi de duas toneladas por hectare de calcário dolomítico, com o objetivo de elevar a saturação de bases para 50\%, sendo metade da dose aplicada antes da aração e a segunda metade, a ntes da gradagem, e também foi feita a aplicação de duas toneladas por hectare de gesso agrícola. A adubação anual $-1$

consistiu de $450 \mathrm{~kg}$.ha de nitrogênio na forma de ureia, $450 \mathrm{~kg}$.ha de $\mathrm{K}_{2} \mathrm{O}$ na forma de cloreto de potássio, aplicados em quatro parcelas iguais em setembro, dezembro, fevereiro e março, $300 \mathrm{~kg}$.ha ${ }^{-1}$ de $\mathrm{P}_{2} \mathrm{O}_{5}$ usando como fonte o superfosfato simples, sendo dois terços aplicados em setembro e o restante em d ezembro. A cada dois anos, foram adicionados mais $100 \mathrm{~kg} \cdot \mathrm{ha}^{-1}$ de FTE BR 12. No primeiro ano foi aplicada apenas a metade da dose anual. 
A determinação dos ciclos de maturação foi feita po r meio da observação semanal dos materiais, seguindo a escala desenvolvida, porém adaptada de Pezzopane et al. (2003), de forma que considerava-se a mudança d e nível apenas quando no mínimo $80 \%$ dos frutos se encontravam no mesmo estádio de maturação. Desta maneira considerando o cereja o ponto ideal para a colheita, foi determinado o tempo, em dias, para que cada material atingisse este estágio, contando a partir do florescimento, que se deu em média em 18/09, aproximadamente duas semanas após o retorno da irrigação, ocorrido geralmente em 04/09. A diferença, em dias para atingir o cereja, entre o material mais precoce (243 dias) e o mais tardio (293 dias), foi de 50 dias. Assim, foram feitos três cortes nas medianas (13, 25 e 38 dias,aproximadamente), formando quatro grupos de maturação, os quais foram denominados Sup erprecoce (243-255 dias), Precoce (256-267), Médio (268-280) e Semitardio (281-293).

No campo experimental existem cerca de 3.500 genóti pos, plantados sem repetição e, portanto, sem delineamento experimenta l. Observações preliminares, especialmente aquelas realizadas por Carneiro et al. (2013), permitiram pré selecionar alguns materiais que haviam produzido no mínimo 7 litros nas duas primeiras safras. A partir daí, foram obtidos os 220 materiais avaliados para força de desprendimento dos frutos. As avaliações de força de desprendimento do s frutos, na safra 2013/14, foram realizadas em cinco estádios de maturação: verde (V), verde-cana (VC), cereja (CE), passa $(\mathrm{P})$ e coco $(\mathrm{CO})$. As medições se deram utiliza ndo-se um dinamômetro da marca Instrutherm ${ }^{\circledR}$, modelo DD 300, como mostra a Figura 2 .1. Foram colhidos, em cada avaliação, seis frutos do terço médio de ramos plag iotrópicos de cada lado da linha de cultivo, totalizando 12 frutos por planta em cada estádio de maturação. O intervalo entre as aferições foi variável, dependendo do ciclo de maturação de cada material, o que permitiu estabelecer o ciclo de maturação de cada m aterial e o intervalo de duração de cada fase do ciclo para cada genótipo. O acompanham ento da maturação e a definição dos estádios foi feito segundo adaptação da escala desenvolvida por Pezzopane et al. (2003). 
Figura 1 - Avaliação da força de desprendimento os frutos com uso do dinamômetro.

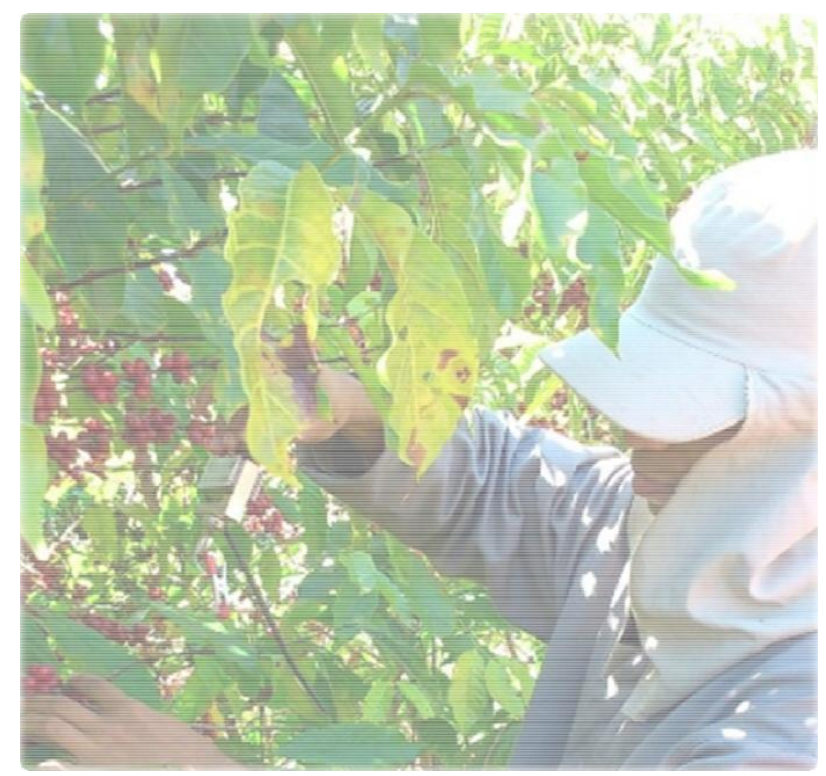

De posse destes dados foi possível determinar a curva de força de desprendimento dos frutos em relação ao ciclo de ma turação, analogamente àquela realizada por Silva (2008). De acordo com o tempo transcorrido para atingir o estádio de cereja, determinado pelos dias após o florescime nto (18/09/2013), os materiais foram divididos em quatro grupos, a saber: superprecoce, precoce, intermediário e tardio. A divisão foi realizada de acordo com as medianas, fa zendo primeiro a divisão em dois grupos maiores e, a partir destes, os quatro grupos supracitados. Os dados de força de desprendimento em cada estádio foram utilizados par determinar a curva de força de desprendimento de cada material, por meio de regressão não-linear, e os parâmetros $b 0$ e b1 da curva logística formada, os quais estão relacion ados, respectivamente, ao intercepto da curva de regressão no eixo Y e à incl inação da parte mais descendente da curva. Este procedimento foi realizado utilizando-se o software R (Ihaka \& Gentleman, 1996), o qual permitiu, também, verificar a significância do ajuste do modelo.

Com a variação da força de desprendimento dos fruto s variou ao longo do ciclo de maturação foi traçado o seguinte modelo de regre ssão polinomial:

$$
\operatorname{Força~}(N)=\frac{\text { Dif }}{1+e^{-\left(b_{0} 0+b 1(\text { Dias })\right)}}+\operatorname{Min}
$$

Em que:

Dif = Diferença entre e a força máxima e a força mínim a;

Mín = Força mínima atingida ao longo do ciclo de matur ação; 
$b 0$ e $b l=$ coeficientes da equação logística;

Dias $=$ dias decorrentes entre a primeira avaliação (no estádio verde, 207 dias após o florescimento) e a data em que se deseja calcular a força.

Este modelo considera a diferença entre as forças m áxima e mínima, que do ponto de vista da colheita mecanizada pode favorecer a colheita seletiva, desde que a força máxima ocorra durante os estádios iniciais ea força mínima, preferencialmente, nos estádios de cereja ou passa. O coeficiente b0, por sua vez, tem relação com o intercepto da curva no eixo Y, que traz uma informação sobre o ponto de partida da força de desprendimento. Do ponto de vista da colhe ita mecanizada, este não é um parâmetro de grande importância, a não ser em casos de grande desuniformidade de maturação dos frutos, fato que não foi observado ne ste experimento principalmente devido à uniformização de florada proporcionada pel o estresse hídrico.

O coeficiente b1 tem grande importância por ter uma relação direta com a queda da força de desprendimento dos frutos: quanto maior seu valor absoluto, mais íngreme será a curva de regressão, ou seja, maior será a redução na força de desprendimento conforme avançam os estádios de maturação dos frutos. Logicamente que este parâmetro também tem estreita relação com a duração do ciclo, sendo ideal que materiais de ciclo mais precoce apresentem a curva com maior inclinação, até porque o prazo de colheita destes materiais é mais justo. Assim, os resultados para cada grupo de maturação serão aqui discutidos separadamente. 


\section{RESULTADOS E DISCUSSÃO}

A força de desprendimento dos frutos variou entre o s genótipos e entre os estádios ao longo do ciclo de maturação. Cada grupo de ciclo foi discutido separadamente.

\section{Ciclo SuperPrecoce}

Cinco materiais foram avaliados pra a força de desp rendimentos dos frutos dentre os classificados aqui como Superprecoces, e a equação obtida foi a seguinte:

$$
\operatorname{Força}(N)=\frac{3,218}{1+e-(10,212+(-0,182)(\text { Dias }))}+1,342
$$

A obtenção dos coeficientes foi altamente significa tiva. Esta equação permitiu a construção da curva de regressão polinomial da fo rça de desprendimento dos frutos dos genótipos Superprecoces, que pode ser vista na Figura 2.

Figura 2 - Força de desprendimento (em Newtons) dos frutos de café Conilon de genótipos superprecoces observada e calculada pelo modelo de regressão em função da evolução do ciclo de maturação. Planaltina, DF, 2016.

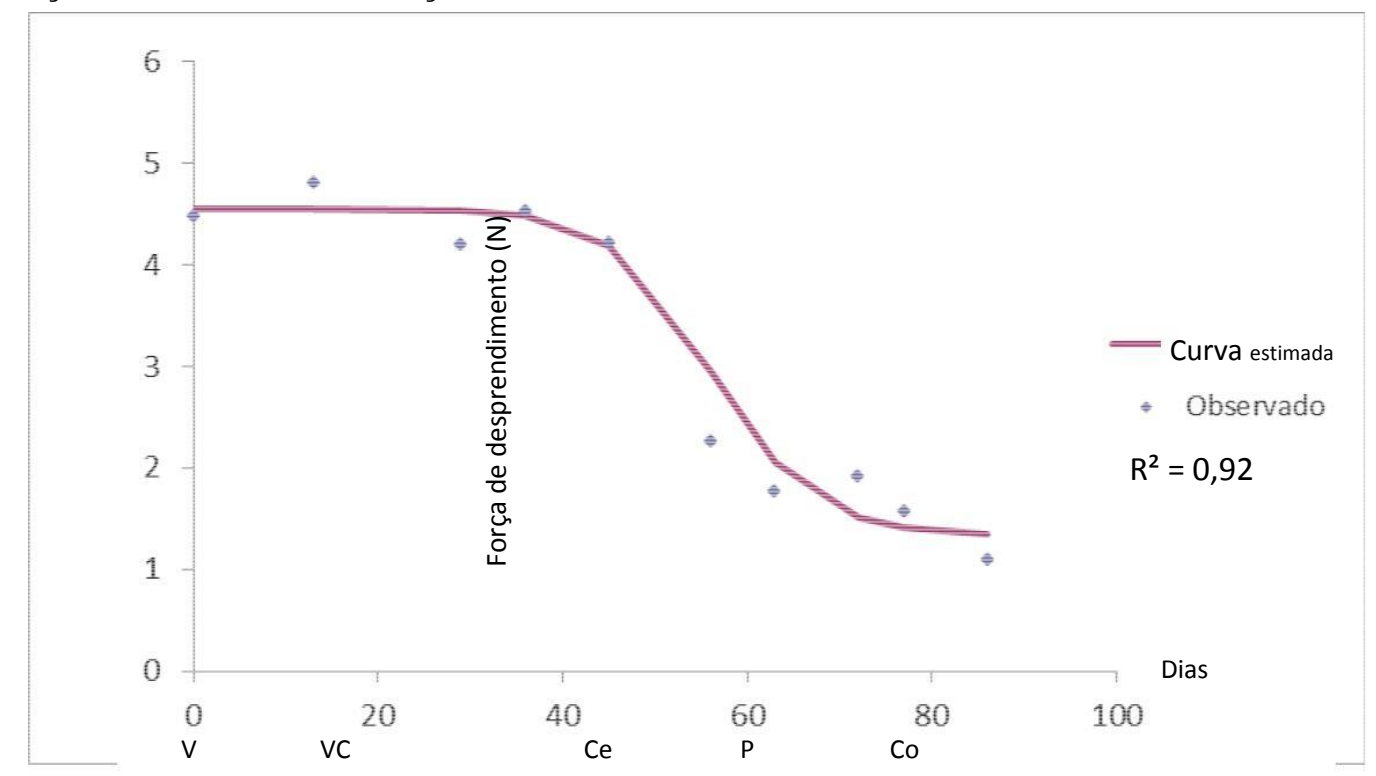

Pode-se depreender, a partir da análise do gráfico,uma vertiginosa queda na força de desprendimento dos frutos a partir do dia 43, período médio em que os genótipos deste grupo de maturação atingiram o está dio de cereja. Esta queda se reflete especialmente no estádio de passa, observado para ste grupo de maturação aos 63 dias, quando a média de força de desprendimento já reduzi significativamente, mostrando 
uma tendência a maior facilidade de colheita nesta fase. Além disto, um ponto importante a ser ressaltado é uma tendência de estabilização da força de desprendimento ao final do ciclo de maturação. Esta observação est á de acordo com o observado por Rena et al. (1994), segundo os quais os frutos de café Conilon são mais fortemente aderidos à planta mesmo ao final do ciclo de matura ção. Este fator pode ser considerado vantajoso no sentido de se observar menor queda espontânea de frutos secos, reduzindo perdas e a incidência de brocas e germinação de sementes abaixo da saia dos cafeeiros.

A Tabela 1 apresenta a média, em dias, para a mudança entre estádios de maturação e seus respectivos desvios, dentro do gru po dos Superprecoces, bem como a média de força de desprendimento para cada estádio.

Tabela 1 - Média e desvio padrão, em dias, para a mudança d e estádio do ciclo de maturação de café Conilon do grupo Superprecoce e média de força de desprendimento, em Newtons, de cada estádio. Planaltina, DF, 2016.

\begin{tabular}{cccc}
\hline Estádio & Dias & Desvio & Força Média (N) \\
\hline Verde & 0 & 0 & 4,5 \\
Verde Cana & 19 & 7,9 & 4,5 \\
Cereja & 43 & 3,6 & 4,3 \\
Passa & 63 & 8,7 & 2,0 \\
Coco & 80 & 6,1 & 1,3 \\
\hline
\end{tabular}

Percebe-se que a passagem de cereja para passa leva, em média, 20 dias. O estádio de passa, porém, é mais curto, chegando aococo em pouco mais de duas semanas. Esta informação é importante no planejamento da atividade, pois representa a janela de colheita. Assim, quanto mais longos forem os estádios cereja e de passa, especialmente o último, no qual a qualidade dos frutos é elevada e a força de desprendimento é baixa, maior será o período adequado de colheita. De modo análogo, quanto mais curto for um estádio ou mais rápida suapassagem ao estádio seguinte, menos tempo hábil haverá para a realização da colheita.

\subsection{Ciclo Precoce}

Para os 151 genótipos aqui classificados como de ci clo precoce, a equação obtida para força de desprendimento dos frutos foi

$$
\operatorname{Força}(N)=\frac{3,528}{1+e-(11,165+(-0,183)(\text { Dias }))}+1,521
$$


Todos os coeficientes obtidos foram altamente significativos para o modelo. A equação proporcionou o desenvolvimento da curva de regressão polinomial de força de desprendimento dos frutos dos genótipos precoces, a presentada na Figura 3.

Figura 3 - Força de desprendimento (em Newtons) dos frutos de café Conilon de genótipos precoces observada e calculada pelo model o de regressão em função da evolução do ciclo de maturação. Planaltina, DF, 2016.

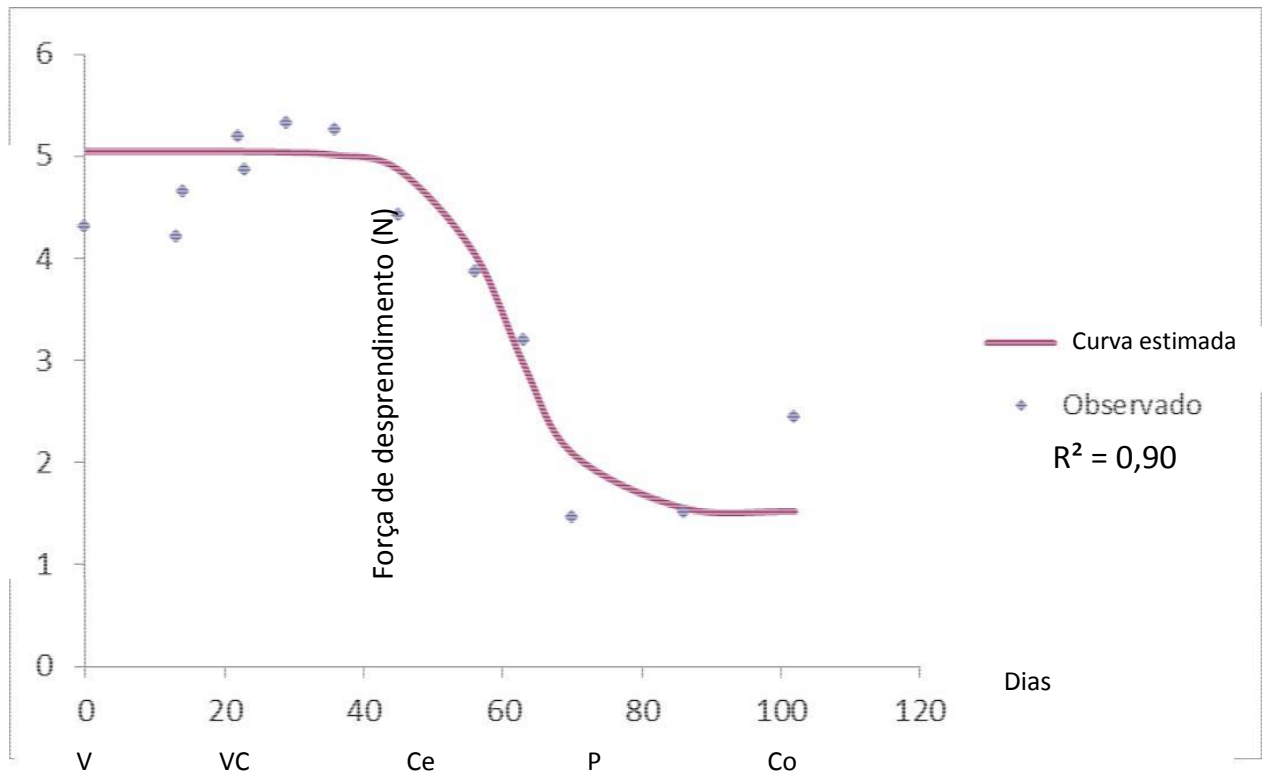

Analisando-se a curva observa-se claramente uma queda significativa na força de desprendimento dos frutos especialmente a partir do dia 59, no qual a maioria dos genótipos deste grupo de maturação atingiram o está dio de cereja. A partir daí, a força de desprendimento seguiu reduzindo, atingindo os menores valores no estádio de passa, a exemplo do que ocorrera com os genótipos do grupo superprecoce. Aqui, isto ocorreu por volta dos 73 dias após a primeira avaliação. A partir daí é perceptível uma leve tendência de aumento da força de desprendimento no estádio de coco, o que leva à conclusão de que os frutos destes materiais não dev em cair espontaneamente, fator, como comentado, vantajoso e de acordo com Rena et al. (1994).

A Tabela 2 apresenta a média, em dias, para a mudança entre estádios de maturação e seus respectivos desvios, dentro do gru po dos genótipos Precoces, bem como a média de força de desprendimento para cada estádio. 
Tabela 2 - Média e desvio padrão, em dias, para a mudança d e estádio do ciclo de maturação de café Conilon do grupo Precoce e média de força de desprendimento, em Newtons, de cada estádio. Planaltina, DF, 2016.

\begin{tabular}{cccc}
\hline Estádio & Dias & Desvio & Força Média (N) \\
\hline Verde & 0 & 0 & 4,3 \\
Verde Cana & 29 & 9,0 & 5,0 \\
Cereja & 59 & 3,4 & 3,6 \\
Passa & 74 & 3,9 & 1,9 \\
Coco & 86 & 0 & 1,5 \\
\hline
\end{tabular}

\subsection{Ciclo médio}

A equação abaixo expressa a força de desprendimento dos frutos em função do estádio de maturação para os 53 genótipos classific ados como de ciclo médio, ou seja, aqueles que levaram de 268 a 280 dias desde o florescimento para atingirem o estádio de cereja.

$$
\operatorname{Força}(N)=\frac{1,843}{1+e^{-(3,934+(-0,059)(\text { Dias }))}}+2,156
$$

Embora a força mínima encontrada neste caso seja um valor relativamente alto (superior a $2 \mathrm{~N}$ ), vê-se que a diferença entre a maior e a menor forças de desprendimento $(1,843 \mathrm{~N})$ tem quase a mesma dimensão, o que leva ao entendimento de que a força maior é quase o dobro da menor. Isto leva a inferir pela possibilidade de colheita mecanizada seletiva, lembrando o raciocínio demonstrado por Silva et al. (2013). A Figura 4 mostra a curva de regressão da f orça de desprendimento dos frutos ao longo do ciclo de maturação. 
Figura 4 - Força de desprendimento (em Newtons) dos frutos de café Conilon de genótipos de ciclo Médio observada e calculada pelo modelo de regressão em função da evolução do ciclo de maturação. Planaltina, DF, 2016.

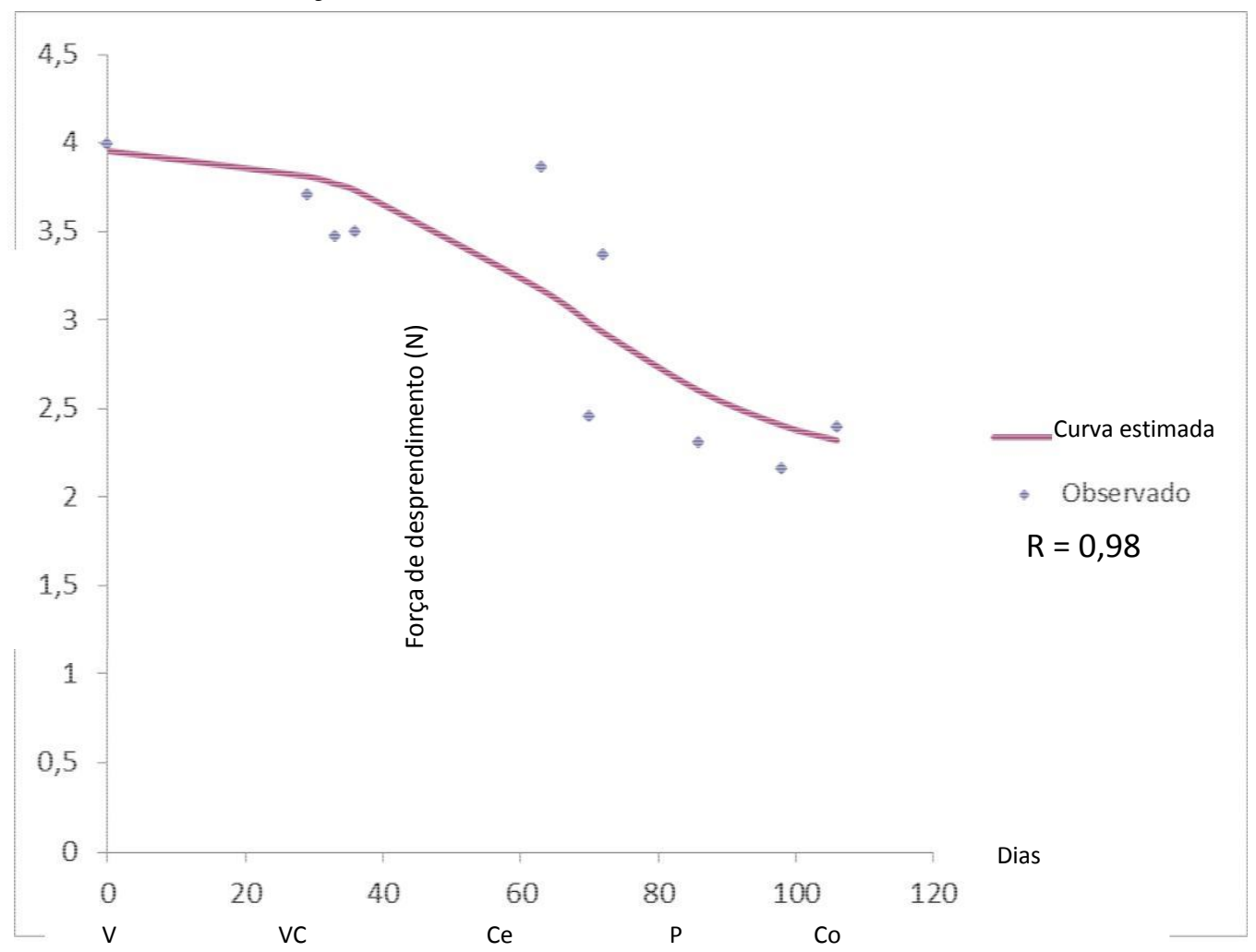

Percebe-se, pela análise do gráfico, que a queda naforça de desprendimento dos frutos não é tão acentuada (curva menos inclinada) quanto as dos grupos anteriores. Isto fica evidenciado pelo valor do parâmetro $b 1$ da equação gerada para a força de desprendimento, que tem um valor absoluto $(0,059)$ consideravelmente menor do que os anteriores $(0,182$ e 0,183 para os Superprecoces e Precoces, respectivamente). Porém, o fato da curva ter menor inclinação, que seria uma d esvantagem do ponto de vista da colheita mecanizada, pode ser atenuado pelo comprimento mais longo do ciclo, o que faz com que a curva seja mais longa, chegando a valores de força de desprendimento mais baixos, quando comparados àqueles obtidos por Silva et al. (2013).

A Tabela 3 mostra a média, em dias, para a mudança entre estádios de maturação e seus respectivos desvios, dentro do gru po dos genótipos Médios, bem como a média de força de desprendimento para cada estádio. 
Tabela 3 - Média e desvio padrão, em dias, para a mudança d e estádio do ciclo de maturação de café Conilon do grupo Médio e média deforça de desprendimento, em Newtons, de cada estádio. Planaltina, DF, 2016.

\begin{tabular}{cccc}
\hline Estádio & Dias & Desvio & Força Média (N) \\
\hline Verde & 0 & 0 & 4,0 \\
Verde Cana & 55 & 9,4 & 4,5 \\
Cereja & 72 & 0,9 & 3,1 \\
Passa & 86 & 2,3 & 1,9 \\
Coco & 99 & 6,7 & 1,5 \\
\hline
\end{tabular}

Verifica-se que a força exigida para o desprendimen to dos frutos verdes tem magnitude maior que o dobro daquela exigida para os frutos no estádio de passa. Percebe-se, portanto, que do ponto de vista da forç a de desprendimento dos frutos como parâmetro para determinação do momento da colheita mecanizada o estádio de passa mostra-se o mais adequado. Ainda com relação à magn itude da força, os resultados encontrados aqui se mostram bem menores do que aqueles encontrados por Silva et al. (2013) para o café arábica para o estádio de cereja.

\subsection{Ciclo Semitardio}

A equação obtida para os 11 genótipos classificados como de ciclo Semitardio está expressa abaixo, na qual todos os coeficientesforam altamente significativos:

$$
\operatorname{Força}(N)=\frac{2,85}{1+e-(6,272+(-0,084)(\text { Dias }))}+1,98
$$

Novamente, assim como ocorrera com os genótipos de ciclo Médio, a força mínima de desprendimento ficou próxima dos 2,0 N. P orém, neste caso em questão o coeficiente $b 0$ da equação apresentou um resultado ligeiramente ma ior, em valor absoluto, do que no grupo de maturação anterior. Is to fez com que a queda na força de desprendimento de frutos fosse mais brusca com a evolução do ciclo de maturação, resultando em uma curva de regressão polinomial mai s inclinada, como se pode observar pela análise da Figura 5 abaixo . 
Figura 5 - Força de desprendimento (em Newtons) dos frutos de café Conilon de genótipos de ciclo Semitardio observada e calculada pelo modelo de regressão em função da evolução do ciclo de maturação. Planaltin a, DF, 2016.

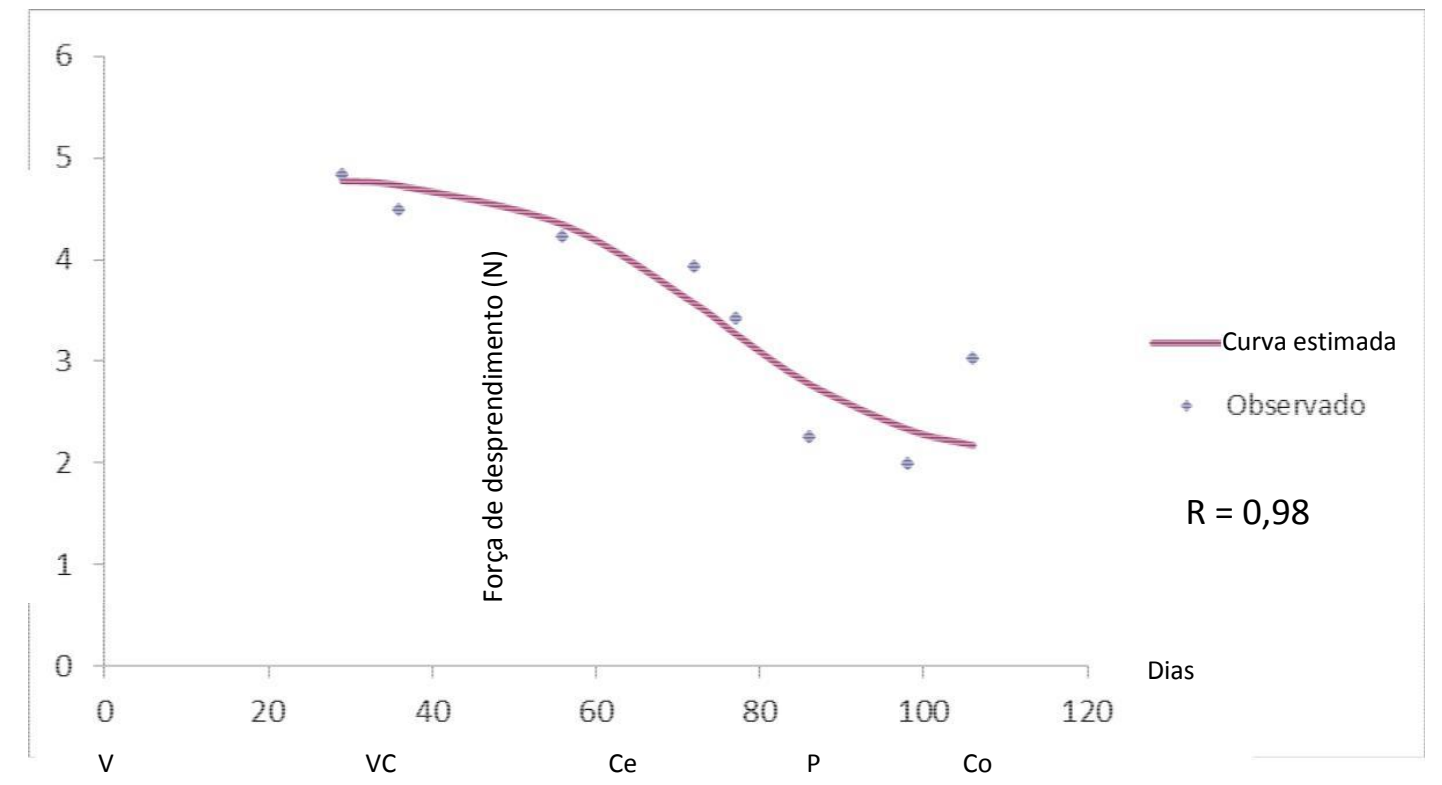

Observa-se, como mencionado acima, uma queda mais brusca na força de desprendimento de frutos, especialmente a partir do dia 77 após a primeira avaliação, quando em os primeiros materiais deste grupo de maturação atingiram o estádio de cereja. A partir daí, a queda torna-se mais acentuada até próximo ao dia 100, quando a maioria dos genótipos já havia passado do estádio ed passa. Neste caso, houve um ligeiro aumento da força ao final do ciclo, fazendo com que a força de desprendimento dos frutos secos fosse maior do que no estádio de passa. Este fator, vale lembrar, é importante no sentido de que se reduz a queda de frutos secos, que causam aumento de custos de produção pela maior incidência de pragas na lavoura, além de reduzir bastante a qualidade da bebida produzida.

Na Tabela 4 é apresentada a média, em dias, para amudança entre estádios de maturação e seus respectivos desvios, dentro do gru po dos genótipos Semitardios, bem como a média de força de desprendimento para cada estádio. 
Tabela 4 - Média e desvio padrão, em dias, para a mudança d e estádio do ciclo de maturação de café Conilon do grupo Semitardio e média de força de desprendimento, em Newtons, de cada estádio. Planaltina, DF, 2016.

\begin{tabular}{cccc}
\hline Estádio & Dias & Desvio & Força Média (N) \\
\hline Verde & 0 & 0 & 3,2 \\
Verde Cana & 50 & 16,6 & 4,4 \\
Cereja & 79 & 3,6 & 3,3 \\
Passa & 89 & 6,6 & 2,3 \\
Coco & 102 & 4 & 2,5 \\
\hline
\end{tabular}

Os materiais de ciclo semitardio apresentaram comportamento ligeiramente diferente dos demais, caracterizado por um aumento nítido da força de desprendimento no estádio de verde cana comparado ao verde, além ed terem mostrado uma força de desprendimento maior no estádio de cereja do que node verde. Com relação ao estádio de passa, seguiu-se a regra percebida nos outros grupos, se mostrando o de maior diferença em relação aos estádios iniciais de matur ação.

Quando se considera os valores absolutos da força d e desprendimento dos frutos, os números médios aqui encontrados para o stádioe de frutos cereja foram comumente menores do que aqueles obtidos por Silva et al. (2013). O comportamento dos materiais ao longo do ciclo de maturação seguiu a lógica já relatada por aqueles autores, que fizeram a comparação entre os estádios de verde e cereja. Importante ressaltar que, como foi observado neste ensaio, o estádio de passa apresentou força de desprendimento consideravelmente menor do que o estádio de cereja, fato que também foi observado por Silva et al. (2008), mostrando-se possivelmente o momento ideal de colheita do ponto de vista da atividade mecanizada, para o café Conilon. Isto porque, além de apresentar valores baixos, no estádio de passa também foram evidenciadas as maiores diferenças de força em relação aos estádios de frutos verde e verde cana, naqueles em que a qualidade da bebida produzida é bastante inferior.

Isso fica ainda mais claro quando se considera que, nos ensaios realizados por Silva et al. (2013), a eficiência de derriça aumentou bastante na segunda passada em relação à primeira (diferença de 28 dias), quando $\mathrm{m}$ esmo os frutos em estádio de cereja já estavam em uma fase mais avançada da maturação d entro do próprio estádio, o que pode ser entendido como o ponto de passa. 
É de grande relevância ressaltar que, independentem ente da força de desprendimento no estádio de cereja, fator importante na mecanização da colheita é a diferença de força entre os estádios. Considerando-se o estádio de passa como o ideal para a colheita mecanizada, constata-se que a diferença entre este e o estádio de cereja foi de 2,5 N para o Superprecoces, 2,4 N para os Precoces, 1,7 N para os Médios e 0,83 N para os Semitardios. Com uma diferença de 3,5 N e ntre os estádios cereja e verde, Silva et al. (2013) obtiveram 77\% de frutos cerejas em relação ao total de frutos colhidos, demonstrando claramente a possibilidade de colheita mecanizada seletiva. Esta pode se mostrar uma excelente alternativa para a colheita em situações de desuniformidade de maturação.

Ainda, embora as diferenças aqui observadas tenham sido menores, $\mathrm{o}$ fato de a força absoluta também ser consideravelmente menor leva a inferir que a regulagem da vibração da colhedora, no caso em tela, pode ser di ferente, com menos ciclos por minuto, o que proporcionaria menos injúrias às plantas durante o processo de colheita, especialmente considerando a possibilidade de danos físicos em gemas florais, fator que gera preocupação especialmente em situações de colh eita tardia. Considerando sobretudo os materiais de ciclo Semitardio aqui estudados, em que o estádio de passa foi observado na segunda quinzena do mês de julho, umacolheita que causasse menos injúrias certamente aceleraria o processo de recuperação da planta após a safra, até pela possibilidade de causar menos desfolha.

Na tabela 5 são apresentadas as datas de ocorrência dos estádios de cereja, passa e coco.

Tabela 5 - Datas aproximadas dos estádios de cereja, passa e coco de genótipos de café Conilon de ciclo Superprecoce, Precoce, Médio e Tardio. Planaltina, 2014.

\begin{tabular}{cccc}
\hline Estádio & Cereja & Passa & Coco \\
\hline$S P$ & $25 / 05$ & $14 / 06$ & $04 / 07$ \\
$P$ & $06 / 06$ & $21 / 06$ & $03 / 07$ \\
$M$ & $19 / 06$ & $03 / 07$ & $16 / 07$ \\
$S T$ & $02 / 07$ & $12 / 07$ & $25 / 07$ \\
\hline
\end{tabular}

Depreende-se da tabela acima as janelas de colheita, considerando-se a época ideal de colheita a faixa entre os estádios de cereja e passa, quando as forças de desprendimento são consideravelmente menores do que no estádio verde e a qualidade dos frutos e o acúmulo de açúcares são maiores do que nos demais estádios. 
A partir daí, seria possível o planejamento da operação, bem como o escalonamento da produção, especialmente se o culti vo do café Conilon for combinado, na mesma propriedade, ao do café Arábica. Nestes casos, deve-se evitar choque com aquela espécie, principalmente por ter o café Arábica um valor de mercado superior ao do Conilon. 


\section{CONCLUSÕES}

- Há variabilidade genética dentro da população estudada em relação à força de desprendimento dos frutos ao longo do ciclo de maturação.

- A força de desprendimento dos frutos presenta que da considerável nos estádios finais da maturação.

- O estádio de passa se mostrou, do ponto de vista da força de desprendimento dos frutos, o ponto ideal de colheita mecanizada do café Conilon irrigado no Cerrado. 


\section{REFERÊNCIAS BIBLIOGRÁFICAS}

CRISOSTO, C. H.; NAGAO, M. A. Evaluation of fruit remove force on coffee cultivars. HortScience, Alexandria, v. 26, n. 2, p. 210-230. 1991.

IHAKA, R.; GENTLEMAN, R. R: A language for data analysis and graphics. Journal of Computational and Graphical Statistics, v. 5, n. 3, p. 299-314. 1996.

KASHIMA, T.; HONDA, A. I.; FAVA, J. F. M.; BASTOS, M. V.; SARTORI, S. Colheita mecânica do café. In: RENA, A. B.; MALAVOLTA, E.; ROCHA, M.; YAMADA, T. Cultura do cafeeiro: fatores que afetam a produtividade. Piracicaba: POTAFÓS, 1986. p. 409-418.

OLIVEIRA, E.; SILVA, F. M.; SALVADOR, N.; SOUZA, Z. M.; CHALFOUN, S. M.; FIGUEIREDO, C. A. P. Custos operacionais da colheita mecanizada do cafeeiro. Pesquisa Agropecuária Brasileira, v.42, n.6, p.827-831, 2007.

PEZZOPANE, J. R. M.; PEDRO JÚNIOR, M. J.; THOMAZIEL LO, R. A.; CAMARGO, M. B. P. Escala para avaliação dos estádios fenológicos do cafeeiro arábica.Bragantia, v. 62, n. 3. Campinas, 2003.

RENA A. B.; BARROS, R. S.; MAESTRI, M.; SÖNDAHL, M. R. Coffee. In: SCHAFTER, B.; ANDERSEN, P.c. (Eds). Handbook or environmental physiology of fruits crops: sub-tropical and tropical crops. Boca Raton: CRC Press, 1994. v.2, Cap. 5, p. 101-122.

SILVA, C. S.; SILVA, F. M.; ALVES, M. C.; BARROS, M. M.; SALES, R. S. Comportamento da força de desprendimento de frutos de cafeeiros ao longo do período de colheita. Ciência e Agrotecnologia,v. 34, n. 2, p. 468-474, 2010.

SILVA, F. C. Efeito da força de despredimento e da maturação dos frutos de cafeeiros na colheita mecanizada. 2008, 122 f. Dissertação (Mestrado em Engenharia Agrícola) - Universidade Federal de Lavras. Lavras, 2008. 
SILVA, F.C.; SILVA, F. M.; SILVA, A. C.; BARROS, M. M.; PALMA, M. A. Z. Desempenho operacional da colheita seletiva do caféem função da força de desprendimento dos frutos. Coffee Science, v. 8, n. 1, p. 53-60. 2013. 


\title{
Capítulo 3
}

\section{REAÇÃO DE GENÓTIPOS DE CAFÉ CONILON ( Coffea canephora Pierre ex Froehner) IRRIGADOS NO Cerrado À FERRUGEM E À CERCOSPORIOSE DO CAFEEIRO}

\begin{abstract}
RESUMO
O presente estudo objetivou avaliar a reação à ferr ugem e à cercosporiose do cafeeiro de genótipos de café Conilon, oriundos de cruzamentos em campo isolado da cultivar Robusta Tropical, em cinco estádios de maturação (verde, verde cana, cereja, passa e coco). O campo experimental, localizado na Embrapa Cerrados, em Planaltina, DF, foi estabelecido em 2009, com irrigação por aspersão vi a pivô central, no espaçamento de 3,5 m x 1,0 m, num experimento sem repetição. A ava liação da reação dos genótipos às doenças foi realizada em seis épocas, com intervalos médios de 37 dias, com base em escalas diagramáticas desenvolvidas para cada doença, por meio de notas, cujas médias em cada época foram usadas, no software SISVAR, para a análise de variância, e pelo software Genes, para estimativa de parâmetros genéticos. Os resultados obtidos demonstram que existe variabilidade dentro da população para reação a estas doenças, com boa quantidade de materiais resistentes, alguns materiais moderadamente resistentes e um material tolerante às duas doenças . A estimativa de parâmetros genéticos para a resistência a essas doenças resultou em uma situação mais favorável à seleção fenotípica para ferrugem, com herdabilidade de 67,37, e pouco menos favorável para cercosporiose do cafeeiro, cuja herdabilidade foi estimada em 45,11.
\end{abstract}

PALAVRAS-CHAVE: herdabilidade; severidade; resistência genética; sel ção fenotípica; tolerância. 


\title{
REACTION OF CONILON COFFEE (Coffea canephora Pierre ex Froehner) GENOTYPES GROWN IRRIGATED IN Cerrado OF DISTRITO FEDERAL TO COOFEE RUST AND CERCOSPORA LEAF SPOT
}

\begin{abstract}
This study aimed to evaluate the reaction of Conilon coffee genotypes to the coofee rust and cercospora leaf spot.

The aim of this study was to evaluate the reaction to coffee leaf rust and cercospora leaf spot of Conilon coffee genotypes derived from crosses in isolated field of the cultivar Robusta Tropical, in Cerrado of Distrito Federal, in an experiment without repetition in the field, with one individual of each genotype, with spacing of $3.5 \mathrm{~m}$ between rows, 1.0 $\mathrm{m}$ between plants and sprinkler irrigation held by central pivot. The evaluation of the genotypes reaction to disease was performed six times with intervals of 37 days, by notes based on diagrammatic scales developed for each disease, which means of each epoch were used in SISVAR software, for analysis of variance, and in Genes software to estimate genetic parameters. The results obtained show that there is variability within the population for reaction to these diseases, with good amount of resistant materials, some moderately resistant materials and one tolerant genotype to the bouth diseases. The of genetic parameters' estimation for resistance to these diseases resulted in a more favorable situation for the phenotypic selection for coffee rust, with an heritability of 67,37 , and slightly less favorable for the coffee cercospora leaf spot, with an heritability of 45,11 .
\end{abstract}

INDEX TERMS: heritability; severity; genetic resistance; phenotipic selection, disease tolerance. 


\section{INTRODUÇÃ̃O}

Dentre as várias doenças que afetam o cafeeiro, destacam-se a ferrugem (Hemileia vastatrix Berkeley \& Broome) e a cercosporiose (Cercospora coffeicola Berkeley \& Cooke).

A obtenção de variedades de cafeeiros com resistência durável à ferrugem tem sido dificultada pela grande variabilidade genética de $H$. vastatrix Berk \& Br., característica muito comum à maioria de patógenos b iotróficos, especialmente os causadores de ferrugens (Silva, 2000). Pereira (2012) afirma que nove genes de resistência à ferrugem, identificados pela sigla $S$, já foram encontrados em diferentes

espécies do gêneroCoffea, especialmente $C$. arabica, $C$. canephora e C. liberica. Em $C$. canephora foram encontrados os genes $\mathrm{S}_{\mathrm{H}} 6,7,8$ e 9. Com isto, diversos cruzamentos vêm sendo feitos entre as espécies $C$. arabica e $C$. canephora, resultando em híbridos interespecíficos como o Híbrido de Timor, por exemplo, resultante do cruzamento natural entre estas espécies. Esta cultivar foi utilizada em diversos programas de melhoramento de café arábica como fonte de resistência à ferrugem, por apresentar, além desta característica, produtividade superior a outros híbridos, fenótipo semelhante ao do café arábica, autofertilidade, menor porcentagem de cafeína comparado ao café robusta e qualidade de bebida regular (Rodrigues Jr. et al., 1975).

Para a cercosporiose ou mancha-de-olho-pardo, assim como para a ferrugem, o uso de cultivares resistentes é a estratégia de manejo mais adequada. Porém, de acordo com Patrício et al. (2010), a resistência à cercosporiose está sendo pouco estudada no Brasil, provavelmente porque os esforços da pesquis a se concentraram no desenvolvimento de cultivares resistentes à ferruge $\mathrm{m}$, a mais importante doença da cultura, ou pelo fato de ser essa doença considerad a de pouca importância para a cultura ou estava relacionada com deficiências na nutrição dos cafeeiros.

Assim, o objetivo deste trabalho é caracterizar a reação destes materiais, cultivados no Cerrado sob irrigação via pivô centra 1 , àquelas que são as principais doenças que afetam a cultura do cafeeiro. 


\section{OBJETIVOS}

- Caracterizar a variabilidade fenotípica de uma população de Coffea canephora irrigada no Cerrado do Distrito Federal com relação à severidade do ataque da ferrugem do cafeeiro (Hemileia vastatrix Berk \& Br.) e da cercosporiose do cafeeiro (Cercospora coffeicola Berk. \& Cooke). 


\section{MATERIAL E MÉTODOS}

O trabalho foi conduzido no Campo Experimental da Embrapa Cerrados, localizada em Planaltina, Distrito Federal, situada a 15'35'30" latitude S, 47² 42 '30" longitude $\mathrm{O}$ e altitude de $1.007 \mathrm{~m}$, num solo classificado como LATOSSOLO VERMELHO Distrófico típico, argiloso. Os resultados médios de análise química do solo na profundidade de $0-20 \mathrm{~cm}$ apresentaram os seguintes resultados: 1,14 mmolc.dm ${ }^{-}$ ${ }^{3}$ de $\mathrm{Al} ; 16,4$ mmolc.dm ${ }^{3}$ de Ca; 0,63 mmolc. dm $^{3}$ de $\mathrm{K} ; 2,5$ mmolc. $\mathrm{dm}^{3}$ de $\mathrm{Mg} ; 59,6$ ppm de P; 27,8 g/kg de matéria orgânica e pH em água de 4,44; areia grossa $=60 \mathrm{~g} \mathrm{~kg}$ ; ; areia fina $=380 \mathrm{~g} \mathrm{~kg}^{-1}$; silte $=130 \mathrm{~g} \mathrm{~kg}^{-1}$ e argila $=430 \mathrm{~g} \mathrm{~kg}^{-1}$.

A área vinha sendo cultivada nos anos anteriores com culturas anuais, e o estabelecimento deste ensaio se deu em abril de 2009, com o espaçamento de 3,5 m entre linhas e 1,0 m entre plantas. Foram avaliados 85 genótipos de C. canephora oriundos de cruzamentos naturais dentro de um campo experimental da cultivar Robusta Tropical (EMCAPER 8151), da Empresa Capixaba de Pesquisa e Extensão Rural EMCAPER - (Ferrão et al., 2000). O método de irriga ção utilizado foi a aspersão, e o sistema adotado foi por pivô central. O critério de manejo da irrigação fundamentou-se no monitoramento do clima, sendo que o momento de irrigação ocorria a cada cinco dias, de acordo com o Programa de Monitoramento de Irrigação do Cerrado (Rocha et al., 2008). Para uniformização da florada, a irrigação era susp ensa em primeiro de julho e retornava sempre que no mínimo $80 \%$ das gemas florais atingiam $80 \%$ do estádio E4, com data limite do retorno da água de irrigação em 4 de setembro de cada ano.

$\mathrm{Na}$ implantação do experimento foram adicionados $120 \mathrm{~g}$ de superfosfato triplo, $50 \mathrm{~g}$ de termofosfato magnesiano (Yoorin ${ }^{\circledR}$ ) e 24,5 $\mathrm{g}$ de fritted trace elements (FTE BR 12) por cova. A calagem foi de duas toneladas por hectare de calcário dolomítico, com o objetivo de elevar a saturação de bases para 50\%, sendo metade da dose aplicada antes da aração e a segunda metade, a ntes da gradagem, e também foi feita a aplicação de duas toneladas por hectare de gesso agrícola. A adubação anual consistiu de $450 \mathrm{~kg}$.ha de nitrogênio na forma de ureia, $450 \mathrm{~kg}$.ha de $\mathrm{K}_{2} \mathrm{O}$ na forma de cloreto de potássio, aplicados em quatro parcelas iguais em setembro, dezembro, fevereiro e março, $300 \mathrm{~kg}$.ha ${ }^{-1}$ de $\mathrm{P}_{2} \mathrm{O}_{5}$ usando como fonte o superfosfato simples, sendo dois terços aplicados em setembro e o restante em d ezembro. A cada dois anos, foram 
adicionados mais $100 \mathrm{~kg} \cdot \mathrm{ha}^{-1}$ de FTE BR 12. No primeiro ano foi aplicada apenas a metade da dose anual.

No campo experimental existem cerca de 3.500 genóti pos, plantados sem repetição e, portanto, sem delineamento experimenta 1. Foram selecionados previamente para as avaliações de reação às doenças 238 materia is genéticos, os quais tiveram produção mínima de 7 litros por planta por duas saf ras consecutivas. Foram realizadas seis avaliações de severidade em intervalos de apro ximadamente 40 dias, quando foram observadas, de acordo com a metodologia definida por Kushalappa e Chaves (1980), oito folhas por planta, no terceiro ou quarto pares de folhas de ramos plagiotrópicos dispostos nos quatro quadrantes e tomados aleatoriamente no terço médio da planta (Souza et al., 2005). Cada genótipo recebeu assim o ito notas, de acordo com as escalas diagramáticas desenvolvidas para ferrugem (Cunha et al., 2001) e cercosporiose (Patrício, 2010).

Foi calculada a média das notas em cada avaliação para cada doença, e a partir desses valores ao longo de todo o ano de 2014 foi calculada a área abaixo da curva de progresso da doença (AACPD). Ainda, considerando ca da época de avaliação como uma repetição, foi realizada a Análise de Variância pelo teste de Scott-Knott a 5\% de significância (Scott \& Knott, 1974) para severidade da ferrugem e da cercosporiose por meio do programa estatístico SISVAR (Ferreira, 2011), com os dados transformados

pelo método $(x+1)^{-2}$. De acordo com os resultados obtidos, foi determinado o grau de resistência de cada material. Foram também estimado as variâncias genotípica e ambiental, para o cálculo da herdabilidade $\left(\mathrm{h}^{2}\right)$ e socoeficientes de variação genotípica e ambiental, por usa vez utilizados para o cálculodo coeficiente de correlação relativa $\left(\mathrm{CV}_{\mathrm{r}}\right)$, com o auxílio do programa Genes (Cruz, 2007), para a severidade de cada uma das doenças.

\section{RESULTADOS E DISCUSSÕES}

\subsection{Ferrugem}

A Figura 1 apresenta as médias de severidade da doença e a área abaixo da curva de progresso da doença (AACPD) para cada genó tipo, bem como a análise de variância

para severidade. 
Figura 1 - Severidade média, média geral do experimento e análise de variância para ferrugem (Hemileia vastatrix) em 238 genótipos de café Conilon irrigado no Distrito Federal. Planaltina, DF, 2016.

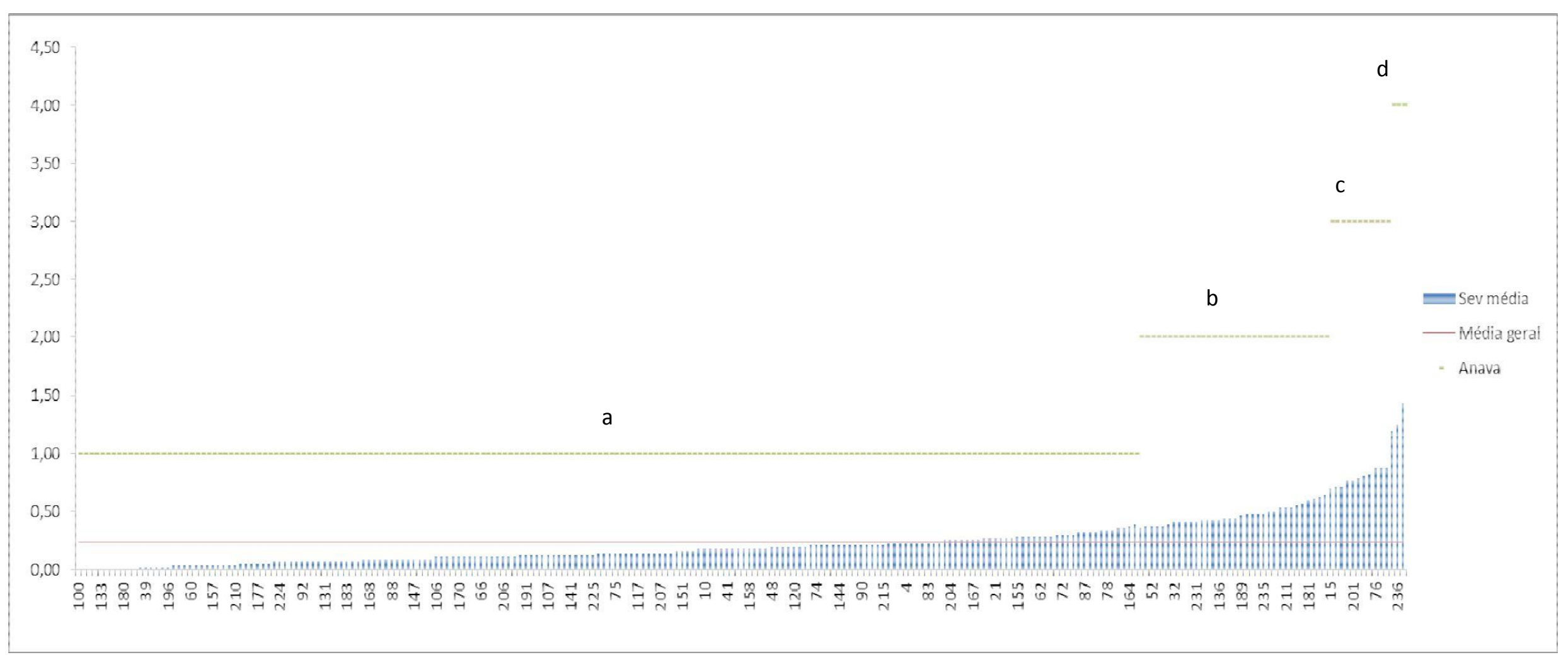

Genótipos da mesma classe não diferem significativa mente no teste de Scott-Knott ao nível de 5\%. CV (\%)= 12,23. 
Os resultados foram altamente significativos para severidade da ferrugem. Foram formados quatro grupos de reação à doença, se ndo o primeiro, com os materiais mais resistentes, o maior deles (190 materiais), o segundo com 34 materiais, o terceiro com 11 e o quarto, dos materiais mais suscetíveis à doença, com 3 representantes. Tais resultados demonstram a baixa suscetibilidade da população à doença, o que é um resultado promissor, especialmente quando se considera que existem experimentos próximos com o cultivo de café arábica há bastantetempo. Paulo et al. (2013) também obtiveram baixos valores de severidade do ataque de ferrugem sobre a cultivar Apoatã no oeste do estado de São Paulo. Costa e colaborado res (2007) observaram grande variabilidade para reação à ferrugem estudando 231 inhagens de Catimor no estado de Minas Gerais. Segundo estes autores, a resistênciapresente no Catimor provavelmente foi herdada de $C$. canephora, considerando que esta cultivar tem em sua genealogia o Híbrido de Timor. Embora em cultivo inicial na região, a população estudada apresenta, portanto, variabilidade para a reação à doença, e e specialmente, fontes de resistência.

Outro ponto importante a ser destacado é que as variedades de café Conilon são constituídas, normalmente, de conjuntos de clon es, os quais costumam apresentar várias características comuns, como homogeneidade de produção, mas diferem no nível de resistência à ferrugem (Ferrão et al., 2007). Desse modo, é necessário que se conheça o nível de resistência dos genótipos que compõem as variedades (Rosado et al., 2011). Portanto, o fato de ter-se obtido aqui um grande número de materiais com bons níveis de resistência à doença possibilita grande número de combinações de genótipos para a formação de variedades clonais.

Considerando o bom desempenho produtivo de boa parte destes materiais na região do Cerrado, verificou-se também a possibilidade de seleção de genótipos para serem utilizados na produção de híbridos com $C$. arabica. A cultivar Icatu, por exemplo, é um marco no melhoramento genético do cafeeiro, por ter encontrado, na hibridação entre as duas espécies, um material rústico, de elevado vigor vegetativo, boa produção e variabilidade para resistência à ferruge m (Alvarenga et al., 1998).

Rezende et al. (2013), trabalhando também com materiais derivados do Híbrido de Timor no município de Campos Altos, MG, obtiveram grande variabilidade para reação à ferrugem. As avaliações realizadas por est es autores ocorreram de forma e em intervalos semelhantes a estas aqui procedidas, e os maiores resultados para AACPD lá encontrados são superiores aos obtidos em Planaltin a durante o ano de 2014. Cabe 
ressaltar que o Híbrido de Timor é, provavelmente, resultado de hibridação natural entre C. arabica e C. canephora (Capucho et al., 2009). Este fator traz mais uma vez à tona a possibilidade do uso de genótipos de Conilon em pro gramas de melhoramento tanto para hibridação quanto para a formação de variedade s clonais resistentes à ferrugem.

Portanto, a partir dos resultados obtidos, e de acordo com as notas das avaliações de severidade, os genótipos estudados fo ram classificados como resistentes (grupos a e b), moderadamente resistentes (grupo c) e moderadamente suscetíveis (grupo d), com relação à ferrugem.

\subsection{Cercospora}

Na Figura 2 são apresentados os resultados obtidos para severidade da doença e a área abaixo da curva de progresso da doença (AACPD) para cada genótipo, bem como a análise de variância para severidade. 
Figura 2 - Severidade média, média geral do experimento e álisen de variância para cercosporiose (Cercospora coffeicola) em 238 genótipos de café Conilon irrigado no Distrito Federal. Planaltina, DF, 2016.

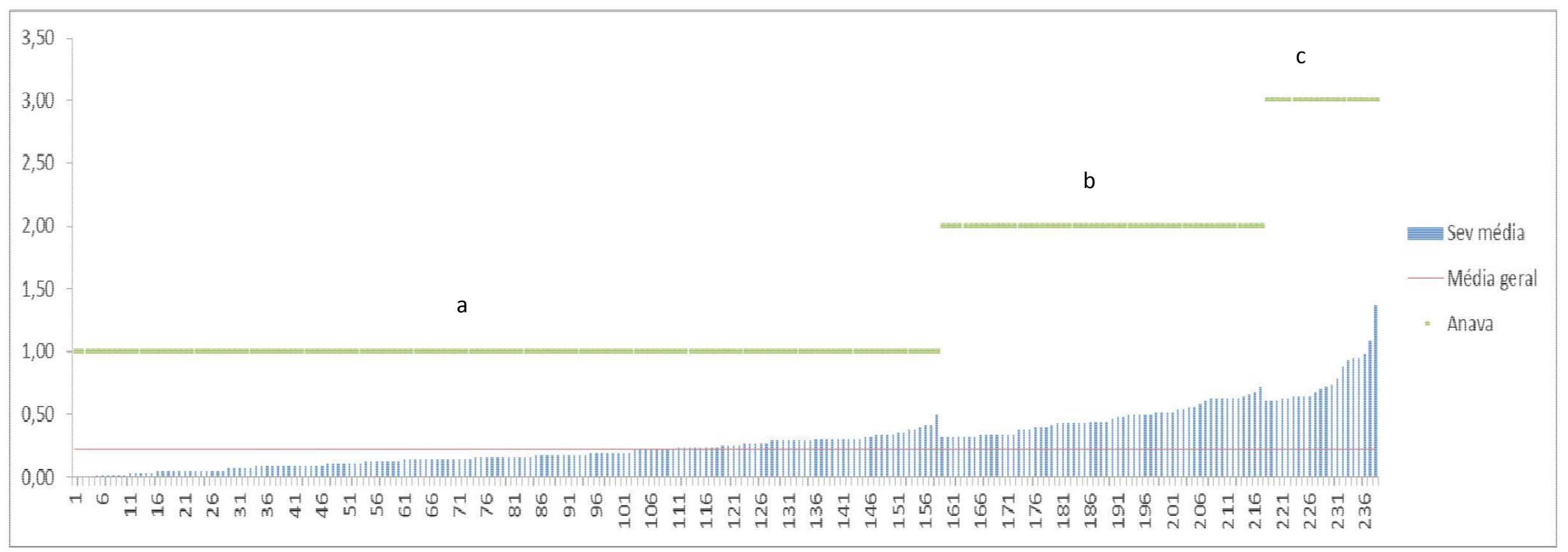

Genótipos da mesma classe não diferem significativa mente no teste de Scott-Knott ao nível de 5\%. CV (\%) = 11,45. 
Observa-se a formação, para esta doença, de três gr upos de reação distintos, sendo o primeiro, com os menores valores de severidade, formado por 158 genótipos, o grupo intermediário com 59 genótipos e o de maiores valores de severidade com 21 materiais genéticos. Mais uma vez, os resultados foram altamente significativos. Para cercosporiose tende a haver uma pequena distinção c om relação à ferrugem: o grupo dos materiais menos afetados é sensivelmente menor(158 contra 180).

A baixa suscetibilidade da população à mancha-de-ol ho-pardo também pode ser considerada bastante positiva quando comparada aos resultados obtidos por Patrício et al. (2010), onde os materiais de C. Canephora, dentre eles a cultivar Apoatã IAC 2258, foram muito suscetíveis à doença. No mesmo tr abalho, estes autores sugerem que se estudem outros representantes da espécie no intuito de se identificarem possíveis fontes de resistência à cercosporiose, considerando-se, além da importância para o melhoramento do cafeeiro, e a grande variabilidade que pode proporcionar, especialmente por tratar-se de espécie alógama, o fato de ter sido usada como fonte de resistência, em programas pretéritos, de nematoides da ferrugem.

Para híbridos interespecíficos, como as cultivares Tupi IAC 1669-33 e Obatã IAC 1669-20, os resultados de Patrício et al. (2010) já foram mais promissores: estes materiais se mostraram moderadamente resistente e moderadamente suscetível, respectivamente. Aqueles autores indicam que a cultivar Tupi IAC 1669-33 pode ser promissora para lavouras ou regiões muito propícias à doença e também para cultivos em sistemas alternativos, nos quais as doenças são um fator limitante. Considerando-se os resultados obtidos aqui, percebe-se que certamente existem materiais bastante promissores neste ponto de vista, seja para integrar variedades clonais de café Conilon, seja para hibridação interespecífica com C. arabica. Obviamente, cabe ressaltar que os trabalhos de Patrício et al. (2010) foram obtidos num experimento com mudas, e plantas jovens tendem a ser mais suscetíveis à mancha-de-ol ho-pardo. Porém, este fator não elimina a tendência favorável encontrada neste ensaio.

Portanto, com os resultados apresentados os materiais puderam ser classificados, quanto ao grau de resistência à cercosporiose, como resistentes (grupos a e b) e moderadamente resistentes (grupo c).

Assim como ocorreu nos trabalhos realizados por Rezende e colaboradores (2013) aqui também nenhuma progênie apresentou imunidade à ferrugem, embora na média das avaliações alguns valores tenham sido bai xos ao ponto de considerados 
severidade zero. No entanto, segundo Botelho et al. (2010), a incidência baixa/intermediária de uma progênie é importante,onsiderandoc-se que não é possível selecionar progênies com resistência horizontal dentre as que não apresentam incidência, pois estas, provavelmente, apresentam esistênciar do tipo vertical ou específica que encobre a resistência horizontal.

Nos dois casos, os resultados mostram a baixa suscetibilidade da população às doenças, o que pode ser considerado um resultado pr omissor. Este fator pode se dever ao fato de que, como a espécie $C$. canephora não é comumente cultivada nesta região, a variabilidade do patógeno aqui existente pode não s er muito virulenta para esta espécie.

O genótipo 82, que apresentou os maiores valores pa ra severidade da cercosporiose, com média de severidade de 1,38 e AACPD de 319,13, e esteve entre os mais atacados também para a ferrugem, se classificando no terceiro grupo, com média de severidade em 0,71 e AACPD de 185,00, foi o primeiro colocado em produtividade (dados do Cap. 1), com 20, 15 e 18 litros produzidos respectivamente nas safras de 2012, 2013 e 2014. Estes resultados demonstram tratar-se, portanto, de um material tolerante às doenças, pois mesmo apresentando nívei s de ataque bem acima da média da população, manteve sua produtividade também bem acima da média. Na safra em que foram realizadas as avaliações de doenças, especifi camente, este genótipo esteve entre os três mais produtivos dentre os 85 materiais colhidos, ficando apenas 1 litro atrás dos líderes em produtividade naquele ano.

Com relação aos parâmetros genéticos, os valores es tão expressos na Tabela 1.

Tabela 1 - Herdabilidades (\%), coeficientes de correlação re lativa $\left(\mathrm{CV}_{\mathrm{r}}\right)$ e coeficientes de variação para severidade do ataque de $H$. vastatrix e $C$. coffeicola em café Conilon irrigado no Cerrado. Planaltina, DF, 2016.

\begin{tabular}{ccc}
\hline Parâmetro & Ferrugem & Cercospora \\
\hline Herdabilidade $\left(\boldsymbol{h}^{2}\right), \boldsymbol{e m} \%$ & 67,37 & 45,11 \\
$\boldsymbol{C} \boldsymbol{V}_{\boldsymbol{g}} / \boldsymbol{C} \boldsymbol{V}_{\boldsymbol{e}}=\boldsymbol{C} \boldsymbol{V}_{\boldsymbol{r}}$ & 0,59 & 0,37 \\
$\boldsymbol{C V}(\boldsymbol{\%})$ & 12,63 & 14,35 \\
\hline
\end{tabular}

Como se pode observar, os valores de herdabilidade da reação às doenças variam consideravelmente. Pelos valores encontrados, infere-se que a seleção para reação à ferrugem deve ser mais eficiente do que aq uela para reação à cercosporiose, visto que mais de $67 \%$ da variação observada é herdável para a primeira doença, enquanto que para a segunda isto ocorre apenas para cerca de $45 \%$. É importante 
lembrar que as doenças de plantas sofrem grande inf luência do ambiente, pois fatores como o microclima e o inóculo inicial podem interfe rir o desempenho dos materiais genéticos.

Desta forma, os valores de $\mathrm{CV}_{\mathrm{r}}$ encontrados podem ser considerados baixos, e estando estes abaixo da unidade, sugerem que no caso da avaliação de doenças os fatores ambientais tiveram grande influência sobrea severidade do ataque. Este fator sugere uma condição desfavorável à seleção para est e caráter, especialmente para a cercosporiose, cujo valor de herdabilidade encontrado foi médio. No caso da ferrugem, o valor mais elevado da herdabilidade favorece um pouco mais a seleção para o caráter com base no fenótipo.

Petek et al. (2008) encontraram valor de $61 \%$ para herdabilidade da resistência a ferrugem, com coeficiente de variação relativa de 0,88. Miranda et al. (2003), por sua vez, obtiveram herdabilidades para resistência a ferrugem em café arábica e híbrido de Timor valores acima de $80 \%$. Avaliando progênies decruzamentos entre híbrido de Timor e Mundo Novo IAC 379-19, encontraram herdabilidades entre 12 e $86 \%$ para resistência a ferrugem. Pereira (2012) estimou a herdabilidade para resistência a ferrugem e cercosporiose, obtendo respectivamente $57,9 \%$ e $0,41 \%$ para progênies de café arábica. No mesmo trabalho, na comparação entr plantas individuais, a mesma autora obteve 19,81\% para resistência a ferrugem e3\% para cercosporiose. Vicentini (2013), obteve, para resistência a ferrugem, herdabilidades individuais de 3,1\% e de $43 \%$ em médias de famílias, trabalhando com 11 famílias de meios-irmãos de café Conilon no Estado do Espírito Santo.

Constata-se, portanto, a grande influência dos fatores ambientais na reação das plantas às doenças, o que corrobora a tendência em se considerar, especialmente, o valor aqui obtido para $\mathrm{h}^{2}$ da resistência à ferrugem como sendo favorável à seleção de materiais para aquela característica. No caso da cercosporiose, embora o valor aqui demonstrado tenha sido bem superior àqueles obtidos por Pereira (2012), não pode ser considerado alto, devendo ser analisado com cautela no caso da seleção de materiais para esta característica. Além disto, naquele trabalho foi percebida uma redução em todas as herdabilidades calculadas quando se considerava a seleção de plantas individuais, que é o que está sendo proposto nestensaio. 


\section{CONCLUSÕES}

- Há variabilidade dentro da população para reação às doenças ferrugem (Hemileia vastatrix) e cercosporiose (Cercospora coffeicola).

- Foram identificados graus de resistêcia a ambas asdoenças em acessos de café Conilon;

- Os resultados de herdabilidade no sentido amplo favorecem a seleção com base no fenótipo, especialmente para a ferrugem. 


\section{REFERÊNCIAS BIBLIOGRÁFICAS}

ALVARENGA, A. P.; VAlE, F. X. R.; MARTINEZ, H. E. P.; PEREIRA, A. A. Produtividade e resistência a ferrugem em progêniesde cafeeiro Icatu. Ciência e Agrotencologia. Lavras, v. 22, n. 2, p. 182-187, 1998.

BOTELHO, C. E.; MENDES, A. N. G.; CARVAlHO, G. R.; BARTHOLO, G. F.; CARVALHO, S. P. Seleção de progênies F4 de cafeeiro obtidas pelo cruzamento de Icatu com Catimor. Revista Ceres, v.57, p. 274-281, 2010.

CAPUCHO A.S.; CAIXETA, E.T.; ZAMBOLIM, E.M.; ZAMBOLIM, L. Herança da resistência do Híbrido de Timor UFV 443-03 à ferrugem do cafeeiro. Pesquisa Agropecuária Brasileira Brasília,. v.44, n.3, p.276-282,mar. 2009.

COSTA, M. J. N.; ZAMBOLIM, L.; CAIXETA, E. T.; PEREIRA, A. A. Resistência de progênies de café Catimor à ferrugemFitopatologia. Brasileira, v. 32, n. 2, 2007.

CUNHA, R. L.; POZZA, E. A.; DIAS, W. P.; BARRETTI, P. B. Desenvolvimento e validação de uma escala diagramática para avaliar a severidade da ferrugem (Hemileia vastatrix Berk \& Br.) do cafeeiro. In: Simpósio de pesquisa d os cafés do Brasil, 1, 2001, Vitória. Resumos expandidos.. Brasília. Embrapa Café, 2001.

FERRÃO, R.G.; FONSECA, A.F.A.; FERRÃO, M.A.G.; BRAG ANÇA, S.M.; VERDIN FILHO, A.C. \& VOLPI, P.S. Cultivares de café conilon. p.203-225 In: FERRÃO, R.G., FONSECA, A.F.A., BRAGANÇA, S.M., FERR ÃO, M.A.G. \& MUNER, L.H. (Eds.) Café Conilon. Vitória-ES: INCAPER. 2007.

FERREIRA, D. F. SISVAR - a computer statistical ana lysis system. Ciência e Agrotecnologia, v. 35, n. 6, Lavras, 2011.

KUSHALAPPA, A. C.; CHAVES, G. M. An analysis of the development of coffee rust in the field. Fitopatologia Brasileira, v.5, n.1, p.95113, 1980.

SILVA, D. G. Levantamento de raças fisiológicas de Hemileia vastatrix Berk \& Br. e resistência de clones deCoffea canephora var. Conilon à ferrugem. 2000, $80 \mathrm{f}$. Tese (Doutorado em Fitopatologia), Universidade Federal de Viçosa. Viçosa, 2000. 
PATRÍCIO, F. R. A.; BRAGHINI, M. T.; FAZUOLI, L. C. Resistência de plantas de Coffea arabica, Coffea canephora e híbridos interespecíficos à cercosporiose. Bragantia, v. 69, n. 4, p. 883-890. Campinas, 2010.

PAUlO, E. M.; MONTES, S. M. N. M.; FISCHER, I. H. Progresso temporal da ferrugem alaranjada em cultivares de cafeeiro no oeste de São Paulo. Arquivos do Instituto Biológico, v. 80, n. 1, p. 59-64. São Paulo, 2013.

PEREIRA, T. B. Seleção de progênies de F4 de cafeeiros utilizando o procedimento REML/BLUP. 2012, 60 f. Dissertação (Mestrado em Fitotecnia), Universidade Federal de Lavras. Lavras, 2012.

PETEK, M. R.; SERA, T.; FONSECA, I. C. B. Exigências climáticas para o desenvolvimento e maturação dos frutos de cultivare s de Coffea arabica. Bragantia, Campinas, v. 68, n. 1, p. 169-181, 2008.

REZENDE, R. M.; PASQUALOTTO, A. T.; REZENDE, J. C.; CARVALHO, A. M.; CARVAlHO, G. R.; TASSONE, G. A. T.; FERREIRA, A. D.; Reação a doenças e produtividade de progênies de cafeeiro oriundas docruzamento entre Híbrido de Timor e Catuaí. In: Simpósio de pesquisa dos cafés do Brasil, 8, 2013. Anais.. Brasília. Embrapa Café, 2013.

RODRIGUES JÚNIOR, C. J.; BETTENCOURT, A. J.; RIJO, L. Races of the pathogen and resistance to coffee rust. Annual Review of Phytopathology, v.13, p.49-70, 1975.

ROSADO, A. W. C.; ZAMBOLIM, L.; CAPUCHO, A. S.; FERRÃO, R. G.; FERRÃO, M. A. G.; FONSECA, A. F. A.; MACIEL-ZAMBOLIM, E.; CAIXETA, E. Resistência do Conilon Vitória 8142 à raça II de Hemileia vastatrix. Simpósio de pesquisa dos cafés do Brasil, 7, 2011, Araxá.Anais.. Brasília. Embrapa Café, 2011.

SOUZA, D. C.; SANTOS, F. S.; SCALCO, M. S.; SOUZA, P. E. Progresso da ferrugem do cafeeiro (Coffea arabica L.) irrigado e não irrigado em diferentes densidades de plantio. In: Simpósio de pesquisa dos cafés do Brasil, 4, 2005, Londrina.

Resumos expandidos.. Brasília. Embrapa Café, 2005. 
VICENTINI, V. B. Análises biométricas em famílias de meios-irmãos decafé

Conilon oriundas de seleção recorrente. 2013, 121f. Tese (Doutorado em Fitotecnia).

Universidade Federal de Viçosa. Viçosa. 2013. 
ANEXO I

\section{Imagens dos experimentos}

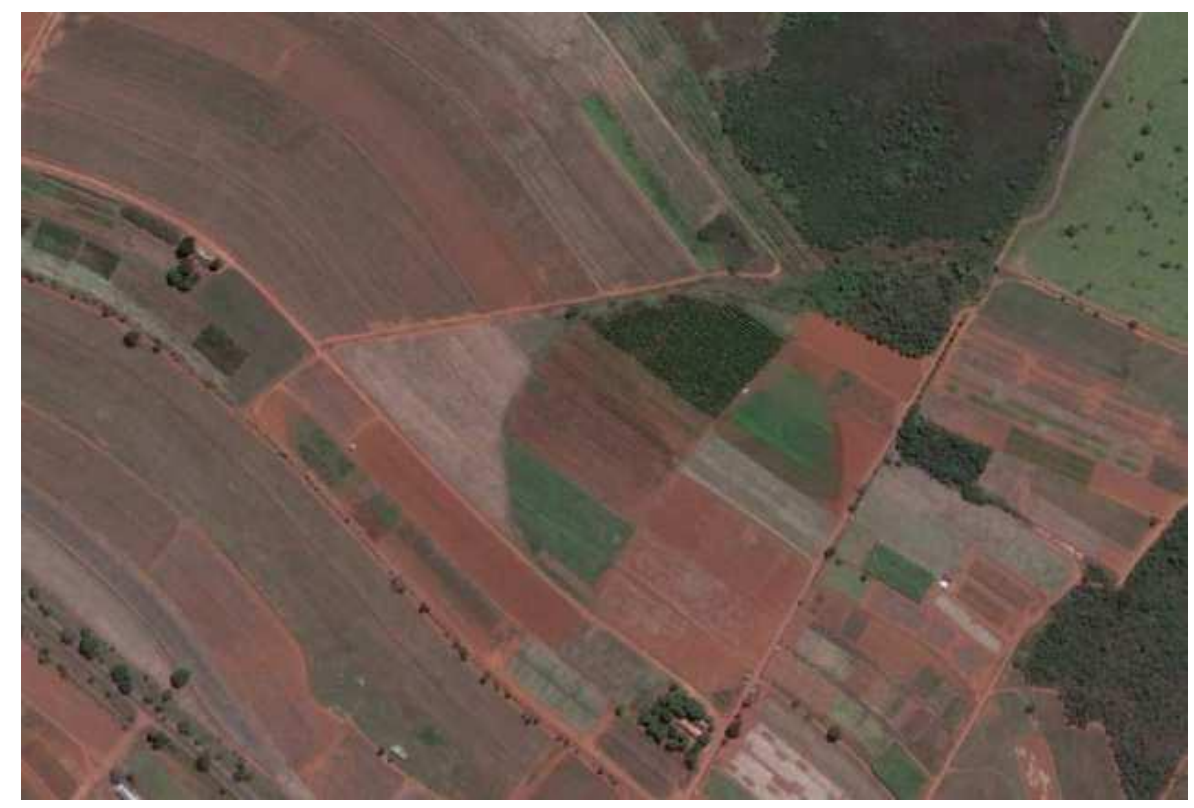

Área experimental, imagem de satélite.

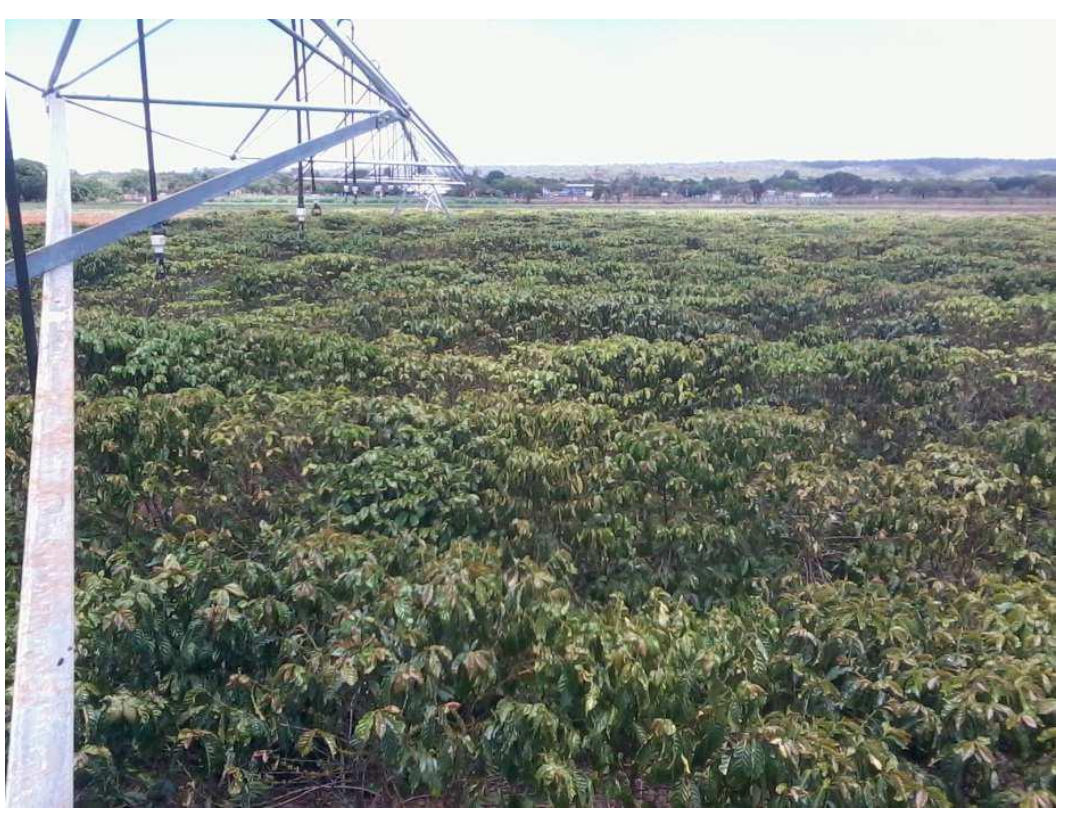

Vista geral da área experimental 


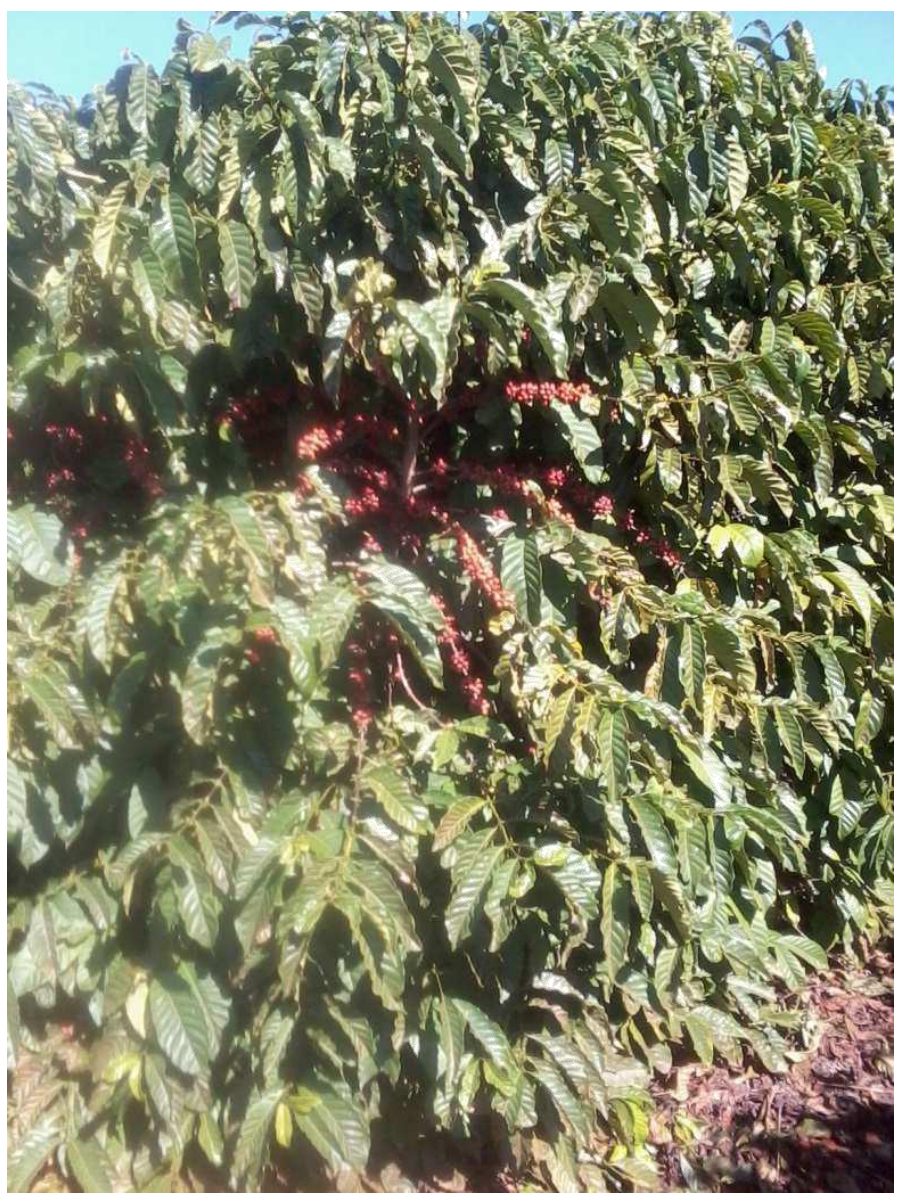

Planta em produção no estádio de cereja

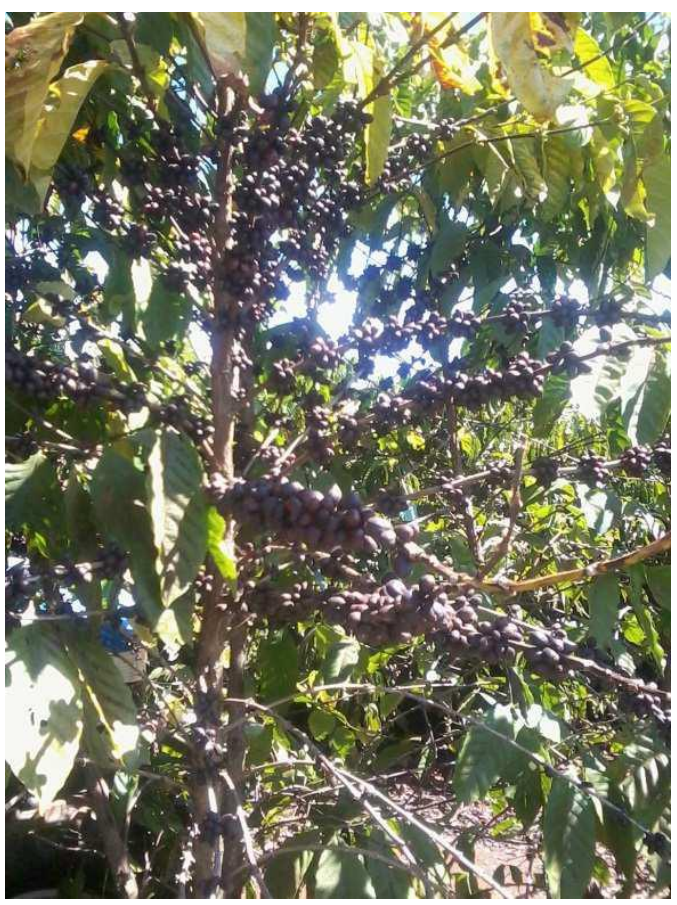

Planta em produção no estádio de coco. 


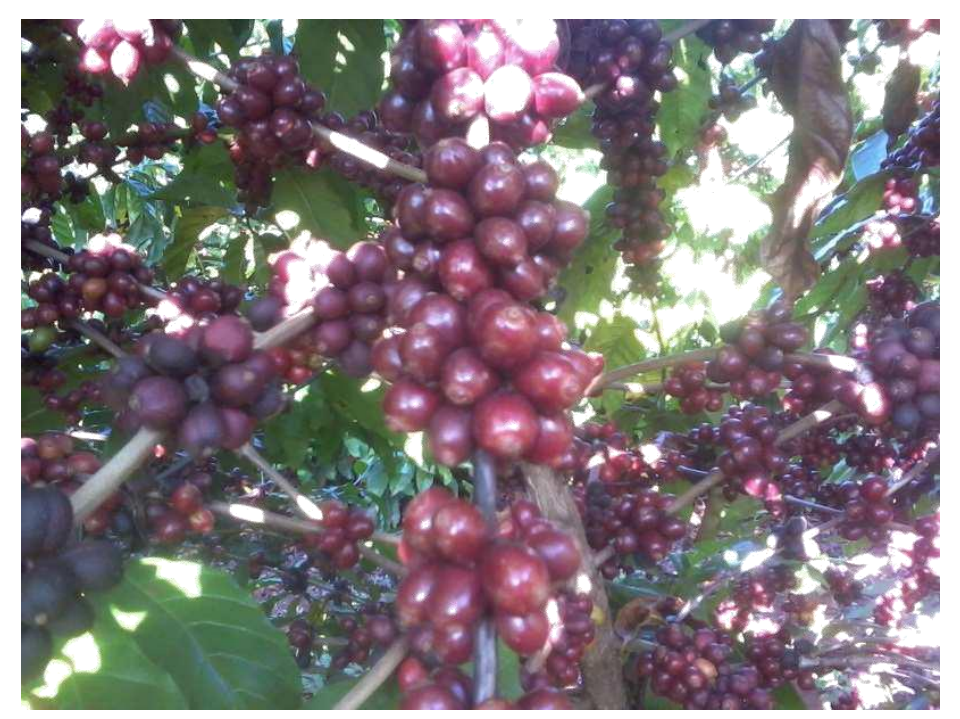

Detalhe de material próximo ao estádio de passa.
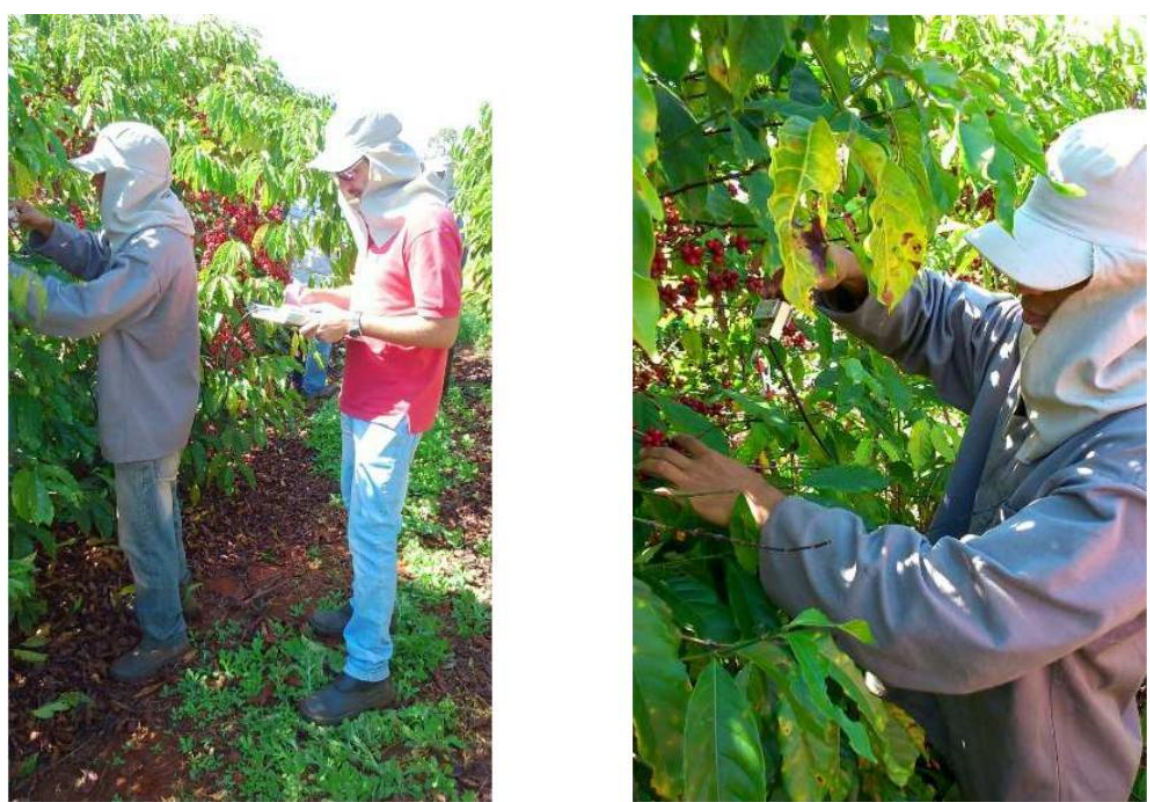

Avaliação de força de desprendimento dos frutos, vi sta geral e em detalhe. 


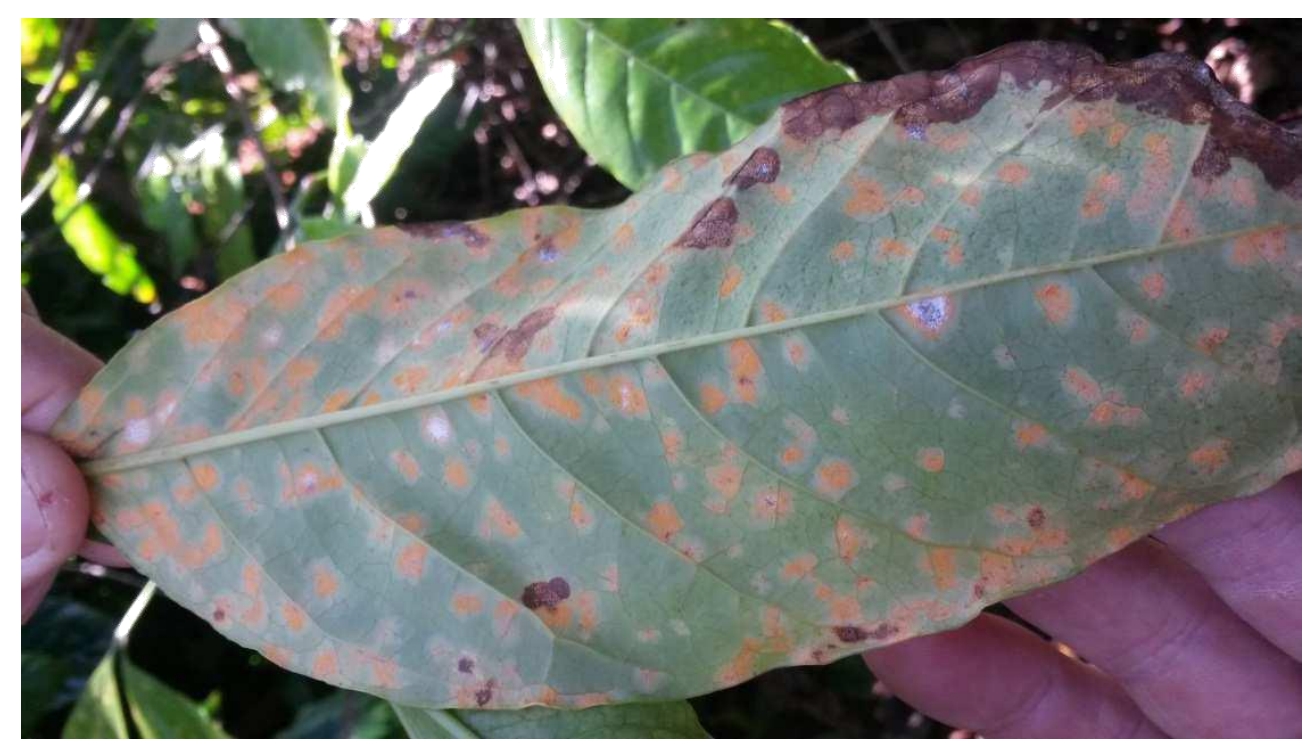

Detalhe de folha com sintomas e sinais de ferrugem (Hemileia vastatrixi)

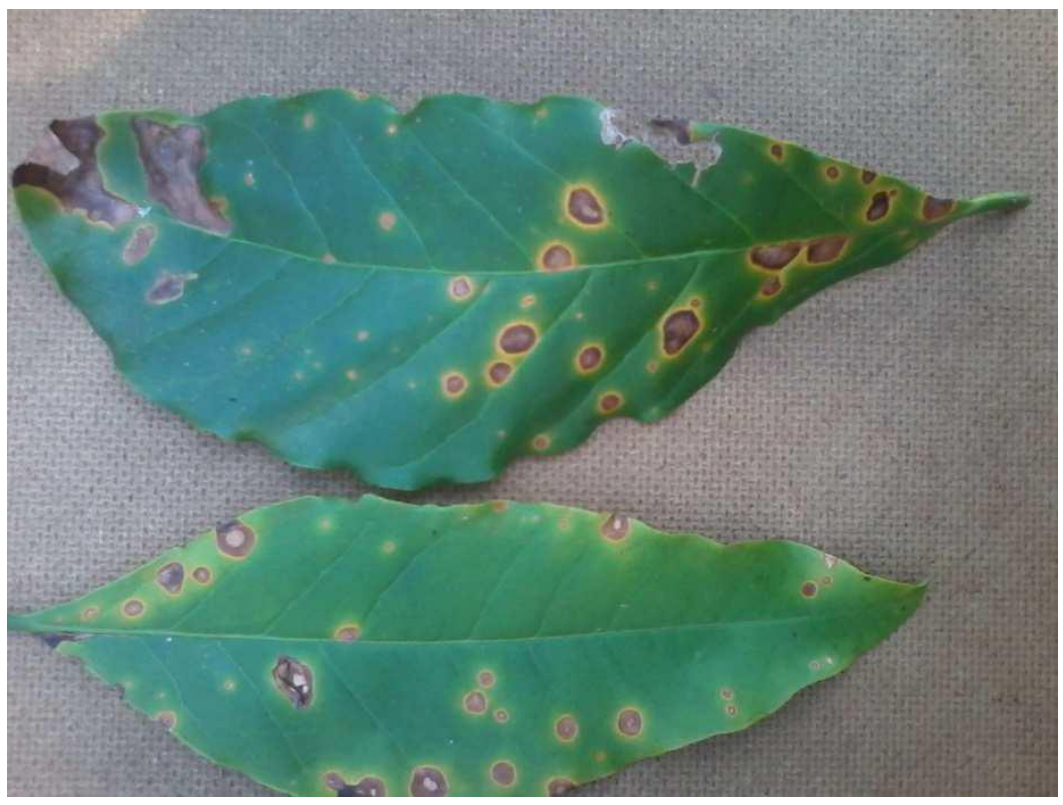

Detalhes de folhas com sintomas de cercosporiose (Cercospora coffeicola). 


\section{ANEXO II}

\section{Análises de solo da área do experimento.}

\begin{tabular}{|c|c|c|c|c|c|c|c|c|c|}
\hline Amostra & $\begin{array}{c}\text { Al - trocável } \\
\text { (Titulometria) }\end{array}$ & $\begin{array}{c}\text { Ca } \\
\text { (Absorção } \\
\text { Atômica) }\end{array}$ & $\begin{array}{c}\text { H+Al - Acidez } \\
\text { Titulável } \\
\text { (Titulometria) }\end{array}$ & $\begin{array}{c}\text { K } \\
\text { (Fotômetro } \\
\text { de Chama) }\end{array}$ & $\begin{array}{l}\text { Mat Org } \\
\text { (Walkley } \\
\text { \& Black) }\end{array}$ & $\begin{array}{c}\text { Mg } \\
\text { (Absorção } \\
\text { Atômica) }\end{array}$ & $\begin{array}{c}\text { pH } \\
\text { em } \\
\text { água }\end{array}$ & $\begin{array}{c}\text { pH } \\
\text { em } \\
\mathrm{CaCl} 2\end{array}$ & $\begin{array}{c}\text { P }(\text { Mehlich1 - } \\
\text { Espectrofotometria })\end{array}$ \\
\hline & $\mathrm{me} / 100 \mathrm{cc}$ & $\mathrm{me} / 100 \mathrm{cc}$ & $\mathrm{me} / 100 \mathrm{cc}$ & $\mathrm{mg} / \mathrm{l}$ & $\%$ & $\mathrm{me} / 100 \mathrm{cc}$ & $\mathrm{pH}$ & $\begin{array}{c}\mathrm{pH} \\
\mathrm{CaCl}\end{array}$ & $\mathrm{mg} / \mathrm{l}$ \\
\hline 1 & 1,39 & 0,85 & 13,845 & 420 & 3,863 & 0,1 & 4,0 & 3,78 & 264,03 \\
\hline 2 & 1,828 & 0,645 & 12,545 & 255 & 2,934 & 0,058 & 3,5 & 3,66 & 99,09 \\
\hline 3 & 1,642 & 0,555 & 9,379 & 210 & 2,48 & 0,083 & 3,8 & 3,84 & 6,494 \\
\hline 4 & 1,426 & 1,245 & 9,866 & 100 & 2,924 & 0,183 & 3,9 & 3,85 & 16,28 \\
\hline 5 & 0,396 & 2,08 & 7,43 & 200 & 2,681 & 0,3 & 4,3 & 4,26 & 5,484 \\
\hline 6 & 1,582 & 1,405 & 13,236 & 215 & 3,652 & 0,167 & 4,1 & 3,81 & 166,96 \\
\hline 7 & 0,068 & 1,7 & 4,71 & 175 & 1,969 & 0,242 & 5,1 & 4,69 & 1,789 \\
\hline 8 & 1,368 & 1,3 & 11,003 & 265 & 2,76 & 0,25 & 4,3 & 3,86 & 63,168 \\
\hline 9 & 0,954 & 0,555 & 7,369 & 220 & 2,433 & 0,133 & 4,3 & 4,07 & 3,32 \\
\hline 10 & 2,442 & 1,525 & 13,378 & 190 & 3,341 & 0,108 & 3,6 & 3,48 & 63,168 \\
\hline 11 & 1,93 & 0,96 & 11,043 & 180 & 3,172 & 0,117 & 3,8 & 3,73 & 19,97 \\
\hline 12 & 1,068 & 0,78 & 8,222 & 165 & 2,385 & 0,108 & 4,1 & 4,02 & 3,622 \\
\hline 13 & 1,826 & 1,085 & 11,916 & 66 & 2,913 & 0,067 & 3,7 & 3,73 & 65,835 \\
\hline 14 & 2,246 & 0,74 & 11,693 & 140 & 2,908 & 0,075 & 3,8 & 3,73 & 44,75 \\
\hline 15 & 1,358 & 0,575 & 8,607 & 130 & 2,322 & 0,092 & 4,0 & 3,96 & 4,135 \\
\hline 16 & 1,852 & 1,135 & 13,418 & 185 & 3,23 & 0,083 & 3,6 & 3,78 & 146,385 \\
\hline 17 & 0,724 & 1,655 & 7,775 & 108 & 2,47 & 0,1 & 4,4 & 4,21 & 10,32 \\
\hline 18 & 0,31 & 1,135 & 5,928 & 136 & 1,958 & 0,125 & 4,7 & 4,42 & 3,005 \\
\hline 19 & 1,042 & 4,1 & 13,723 & 285 & 4,122 & 0,275 & 4,0 & 3,91 & 261,36 \\
\hline 20 & 0,156 & 3,96 & 9,764 & 570 & 2,48 & 0,175 & 4,9 & 4,57 & 258,05 \\
\hline 21 & 0,658 & 1,365 & 7,876 & 400 & 2,792 & 0,1 & 4,7 & 4,19 & 9,122 \\
\hline 22 & 1,198 & 2,115 & 11,957 & 210 & 3,81 & 0,142 & 4,2 & 3,81 & 92,1 \\
\hline 23 & 1,254 & 1,155 & 9,135 & 205 & 2,966 & 0,117 & 4,2 & 3,94 & 9,448 \\
\hline 24 & 0,978 & 0,89 & 7,166 & 260 & 1,742 & 0,108 & 4,2 & 4,08 & 2,247 \\
\hline 25 & 0,648 & 4,75 & 12,647 & 335 & 4,401 & 0,242 & 4,4 & 4,23 & 239,94 \\
\hline 26 & 0,79 & 1,905 & 9,703 & 180 & 3,066 & 0,117 & 4,5 & 4,16 & 36,31 \\
\hline 27 & 0,642 & 1,345 & 7,552 & 220 & 2,338 & 0,133 & 4,5 & 4,24 & 5,776 \\
\hline 28 & 1,886 & 0,385 & 12,972 & 610 & 3,235 & 0,042 & 4,0 & 3,72 & 180,685 \\
\hline 29 & 2,148 & 0,345 & 11,713 & 470 & 3,108 & 0,05 & 3,7 & 3,65 & 24,47 \\
\hline 30 & 2,194 & 0,31 & 11,003 & 395 & 2,586 & 0,058 & 3,6 & 3,68 & 13,88 \\
\hline 31 & 2,018 & 0,855 & 12,809 & 150 & 3,035 & 0,092 & 3,9 & 3,71 & 110,585 \\
\hline 32 & 2,04 & 0,59 & $2.095,79$ & 142 & 2,697 & 0,067 & 4,9 & 3,81 & 53,116 \\
\hline 33 & 1,72 & 0,565 & 8,628 & 205 & 2,306 & 0,083 & 4,0 & 3,91 & 4,186 \\
\hline 34 & 1,598 & 1,355 & 15,651 & 720 & 4,401 & 0,108 & 3,8 & 3,79 & 476,66 \\
\hline
\end{tabular}




\begin{tabular}{|c|c|c|c|c|c|c|c|c|c|}
\hline 35 & 1,926 & 0,67 & 10,475 & 460 & 3,108 & 0,067 & 3,9 & 3,81 & 27,19 \\
\hline 36 & 1,706 & 0,69 & 8,891 & 235 & 2,75 & 0,075 & 4,0 & 3,93 & 6,79 \\
\hline 37 & 1,356 & 1,375 & 12,424 & 235 & 2,866 & 0,1 & 4,3 & 3,89 & 198,03 \\
\hline 38 & 1,39 & 0,91 & 9,5 & 280 & 2,929 & 0,142 & 4,3 & 3,93 & 22,91 \\
\hline 39 & 1,192 & 0,505 & 8,201 & 370 & 2,159 & 0,117 & 4,1 & 3,97 & 4,266 \\
\hline 40 & 1,34 & 1,44 & 11,429 & 108 & 3,114 & 0,092 & 4,1 & 3,94 & 94,27 \\
\hline 41 & 1,152 & 1,33 & 9,135 & 114 & 2,771 & 0,108 & 4,2 & 3,99 & 15,56 \\
\hline 42 & 0,76 & 0,975 & 7,004 & 144 & 2,444 & 0,117 & 4,4 & 4,15 & 2,235 \\
\hline 43 & 1,762 & 0,99 & 11,267 & 138 & 2,744 & 0,108 & 3,9 & 3,75 & 51,356 \\
\hline 44 & 0,83 & 1,255 & 8,222 & 160 & 2,961 & 0,142 & 4,2 & 4,04 & 7,804 \\
\hline 45 & 0,476 & 1,095 & 6,435 & 195 & 2,306 & 0,192 & 4,4 & 4,26 & 3,333 \\
\hline 46 & 1,036 & 1,225 & 10,901 & 620 & 3,04 & 0,125 & 4,3 & 4,04 & 99,31 \\
\hline 47 & 2,194 & 0,78 & 11,206 & 590 & 2,771 & 0,1 & 3,7 & 3,66 & 17,91 \\
\hline 48 & 1,516 & 0,485 & 8,1 & 355 & 2,375 & 0,067 & 3,9 & 3,85 & 4,27 \\
\hline 49 & 1,438 & 2,12 & 13,5 & 150 & 4,423 & 0,133 & 4,0 & 3,81 & 181,2 \\
\hline 50 & 1,054 & 2,2 & 9,906 & 108 & 2,839 & 0,125 & 4,3 & 4,04 & 26,28 \\
\hline 51 & 0,988 & 1,26 & 7,572 & 100 & 2,565 & 0,133 & 4,3 & 4,03 & 2,74 \\
\hline 52 & 1,024 & 1,805 & 9,744 & 370 & 3,436 & 0,192 & 4,2 & 4,01 & 34,37 \\
\hline 53 & 0,504 & 1,75 & 7,186 & 370 & 3,04 & 0,275 & 4,0 & 4,32 & 5,555 \\
\hline 54 & 0,706 & 0,685 & 6,455 & 270 & 2,728 & 0,192 & 4,3 & 4,15 & 3,234 \\
\hline 55 & 1,252 & 1,565 & 12,586 & 470 & 2,929 & 0,217 & 3,9 & 3,78 & 540,6 \\
\hline 56 & 1,681 & 1,18 & 10,597 & 380 & 2,57 & 0,125 & 4,0 & 3,82 & 53,994 \\
\hline 57 & 1,593 & 0,56 & 8,77 & 500 & 2,422 & 0,108 & 4,1 & 3,94 & 6,807 \\
\hline 58 & 1,217 & 1,13 & 12,139 & 490 & 3,478 & 0,092 & 4,4 & 3,93 & 159,82 \\
\hline 59 & 1,351 & 0,62 & 9,805 & 410 & 2,438 & 0,092 & 4,2 & 3,96 & 26,79 \\
\hline 60 & 1,403 & 0,28 & 7,856 & 480 & 1,789 & 0,067 & 4,2 & 3,95 & 2,529 \\
\hline 61 & 1,365 & 1,77 & 11,348 & 610 & 2,707 & 0,133 & 3,8 & 3,79 & 119,85 \\
\hline 62 & 0,849 & 1,305 & 8,485 & 330 & 2,375 & 0,225 & 4,4 & 4,14 & 9,775 \\
\hline 63 & 0,523 & 0,775 & 6,435 & 255 & 2,301 & 0,1 & 4,4 & 4,18 & 2,583 \\
\hline 64 & 1,289 & 1,555 & 14,068 & 780 & 3,383 & 0,15 & 3,8 & 3,81 & 320,7 \\
\hline 65 & 1,695 & 0,9 & 11,612 & 620 & 2,987 & 0,092 & 3,6 & 3,72 & 132,0 \\
\hline 66 & 1,659 & 0,865 & 11,104 & 450 & 2,76 & 0,092 & 3,8 & 3,82 & 31,91 \\
\hline 67 & 1,461 & 1,12 & 14,839 & 430 & 3,04 & 0,058 & 3,9 & 3,78 & 266,7 \\
\hline 68 & 1,567 & 1,445 & 11,551 & 325 & 2,633 & 0,083 & 3,9 & 3,84 & 80,45 \\
\hline 69 & 1,449 & 0,875 & 8,973 & 400 & 2,074 & 0,1 & 4,0 & 3,93 & 9,388 \\
\hline 70 & 1,745 & 1,385 & 12,444 & 240 & 3,309 & 0,1 & 3,9 & 3,83 & 58,16 \\
\hline 71 & 1,821 & 1,035 & 11,429 & 410 & 3,689 & 0,108 & 3,8 & 3,84 & 8,366 \\
\hline 72 & 1,825 & 0,595 & 11,368 & 355 & 3,24 & 0,075 & 3,8 & 3,88 & 11,06 \\
\hline 73 & 0,039 & 4,65 & 6,902 & 138 & 3,14 & 0,683 & 5,3 & 5,04 & 26,37 \\
\hline 74 & 0,033 & 3,95 & 5,562 & 94 & 2,718 & 0,708 & 5,5 & 5,25 & 7,47 \\
\hline 75 & 0,011 & 2,41 & 4,446 & 136 & 2,116 & 0,483 & 5,7 & 5,34 & 1,449 \\
\hline 76 & 1,835 & 1,98 & 15,631 & 550 & 3,093 & 0,2 & 3,8 & 3,78 & 132,9 \\
\hline 77 & 2,323 & 1,18 & 12,606 & 460 & 2,649 & 0,142 & 3,7 & 3,72 & 32,43 \\
\hline 78 & 2,395 & 0,31 & 11,754 & 320 & 2,354 & 0,067 & 3,7 & 3,73 & 4,714 \\
\hline 79 & 1,123 & 1,605 & 13,845 & 385 & 2,771 & 0,133 & 4,1 & 3,89 & 231,7 \\
\hline
\end{tabular}




\begin{tabular}{|c|c|c|c|c|c|c|c|c|c|}
\hline 80 & 2,017 & 0,58 & 11,754 & 370 & 2,465 & 0,092 & 4,0 & 3,79 & 20,19 \\
\hline 81 & 1,759 & 0,285 & 10,414 & 295 & 2,491 & 0,058 & 3,9 & 3,85 & 4,251 \\
\hline 82 & 2,051 & 1,52 & 14,494 & 118 & 3,351 & 0,108 & 3,8 & 3,74 & 107,085 \\
\hline 83 & 2,155 & 1,125 & 12,809 & 112 & 2,771 & 0,125 & 3,9 & 3,74 & 28,93 \\
\hline 84 & 2,429 & 0,35 & 10,718 & 90 & 2,475 & 0,075 & 3,7 & 3,79 & 5,448 \\
\hline 85 & 3,253 & 0,9 & 15,57 & 165 & 2,94 & 0,1 & 3,5 & 3,55 & 105,425 \\
\hline 86 & 3,193 & 0,64 & 13,54 & 215 & 2,364 & 0,108 & 3,4 & 3,56 & 18,72 \\
\hline 87 & 2,729 & 0,145 & 10,353 & 148 & 2,169 & 0,05 & 3,6 & 3,74 & 3,96 \\
\hline 88 & 2,031 & 1,73 & 14,535 & 195 & 3,367 & 0,092 & 3,7 & 3,66 & 172,565 \\
\hline 89 & 1,861 & 1,685 & 13,601 & 155 & 2,871 & 0,075 & 3,8 & 3,72 & 124,18 \\
\hline 90 & 1,717 & 1,25 & 10,333 & 170 & 2,375 & 0,083 & 3,8 & 3,86 & 6,04 \\
\hline 91 & 0,005 & 2,95 & 5,806 & 68 & 2,802 & 1,208 & 5,7 & 5,25 & 9,211 \\
\hline 92 & 0,005 & 3,75 & 5,197 & 36 & 2,565 & 0,958 & 5,9 & 5,45 & 4,931 \\
\hline 93 & 0,009 & 3,955 & 6,963 & 155 & 2,913 & 0,833 & 5,7 & 5,71 & 12,8 \\
\hline 94 & 0,003 & 3,6 & 5,197 & 70 & 2,633 & 0,808 & 5,8 & 5,45 & 4,047 \\
\hline 95 & 0,289 & 2,415 & 8,12 & 23 & 2,554 & 0,367 & 4,9 & 4,61 & 7,928 \\
\hline 96 & 0,163 & 1,29 & 6,963 & 17 & 2,38 & 0,15 & 5,2 & 4,66 & 1,804 \\
\hline 97 & 0,071 & 3,09 & 7,836 & 31 & 2,95 & 0,725 & 5,2 & 4,86 & 14,18 \\
\hline 98 & 0,097 & 1,245 & 6,374 & 19 & 1,731 & 0,3 & 5,3 & 4,73 & 1,695 \\
\hline 99 & 0,005 & 2,55 & 6,963 & 142 & 2,792 & 0,583 & 5,6 & 5,18 & 22,12 \\
\hline 100 & 0,019 & 3,395 & 5,522 & 45 & 2,317 & 0,567 & 5,9 & 5,38 & 3,404 \\
\hline 101 & 0,013 & 2,9 & 6,374 & 21 & 2,544 & 0,983 & 5,7 & 5,36 & 11,44 \\
\hline 102 & 0,007 & 4,035 & 4,344 & 23 & 2,238 & 0,942 & 6,7 & 5,74 & 2,343 \\
\hline 103 & 0,035 & 3,975 & 7,613 & 46 & 3,346 & 0,825 & 5,4 & 4,98 & 26,99 \\
\hline 104 & 0,005 & 3,14 & 5,42 & 51 & 2,433 & 0,617 & 5,6 & 5,18 & 2,903 \\
\hline 105 & 0,007 & 3,485 & 6,496 & 170 & 2,776 & 0,65 & 5,6 & 5,11 & 10,36 \\
\hline 106 & 0,003 & 2,63 & 5,258 & 71 & 2,301 & 0,483 & 5,7 & 5,22 & 1,627 \\
\hline 107 & 0,013 & 3,15 & 6,171 & 56 & 2,475 & 0,858 & 5,8 & 5,37 & 38,85 \\
\hline 108 & 0,029 & 2,175 & 6,029 & 46 & 2,343 & 0,517 & 5,6 & 4,97 & 4,895 \\
\hline 109 & 0,005 & 3,15 & 6,983 & 142 & 2,422 & 0,733 & 5,8 & 5,32 & 48,338 \\
\hline 110 & 0,005 & 3,085 & 4,933 & 140 & 2,275 & 0,558 & 5,9 & 5,51 & 4,334 \\
\hline 111 & 0,069 & 3,51 & 8,749 & 80 & 3,114 & 0,533 & 5,1 & 4,82 & 70,836 \\
\hline 112 & 0,225 & 1,98 & 7,125 & 44 & 2,475 & 0,342 & 5,1 & 4,62 & 6,378 \\
\hline 113 & 0,021 & 3 & 7,064 & 50 & 2,744 & 0,567 & 5,3 & 4,95 & 28,1 \\
\hline 114 & 0,005 & 3,72 & 4,06 & 96 & 2,143 & 0,733 & 5,9 & 5,68 & 2,183 \\
\hline Média & 1,14 & 1,64 & 27,92 & 243,702 & 2,778 & 0,247 & 4,4 & 4,20 & 59,576 \\
\hline
\end{tabular}




\section{ANEXO III}

Resumos das análises estatísticas

\section{CAPÍTULO 1}

\section{Análise de repetibilidade para produtividade}

SELEGEN-REML/BLUP Inicio : 1993 Versao Atual : Janeiro 2008 AD

Sistema Estatistico e Selecao Genetica Computadorizada

Modelos Lineares Mistos via REML/BLUP e REML/GLS

Empresa Brasileira de Pesquisa Agropecuaria

Embrapa Florestas

Ministerio da Agricultura e do Abastecimento

Informacoes : Marcos Deon Vilela de Resende

Universidade Federal de Viçosa Vi çosa - MG

marcos.deon@gmail.com

marcos.deon@ufv.br

Arquivo $\quad: \mathrm{F}:$ Doutorado\Projeto\Selegen $\backslash$ Arquivos selegen\Prod 3 colheitas CV 25.txt

Modelo : 63

Numero de Variaveis : 1

Variavel Analisada : 1

N. Dados Lidos : 255

Zeros significativos : Nao

Deviance $=772.90$

Valores Qui-Quadrado

1 grau de liberdade 0.5 grau de liberdade

$1 \%=6.63 \quad 2.5 \%=3.84$

$5 \%=3.84 \quad 5 \%=2.71$

$10 \%=2.71$

Data : 03/03/2016

Hora : 17:51:46

1. Componentes de Variância ( REML Individual)

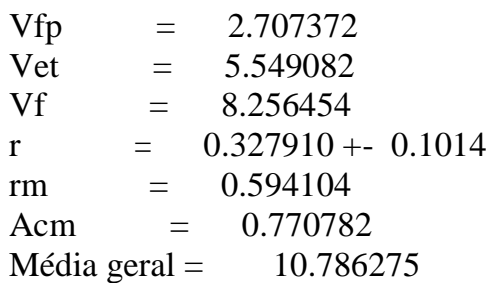

Eficiencia do uso de m medidas

$\begin{array}{cccc}\mathrm{m} & \text { Determinacao } & \text { Acuracia } & \text { Eficiencia } \\ 1 & 0.327910 & 0.572634 & 1.000000 \\ 2 & 0.493874 & 0.702761 & 1.227243 \\ 3 & 0.594104 & 0.770782 & 1.346028 \\ 4 & 0.661199 & 0.813141 & 1.420001 \\ 5 & 0.709258 & 0.842175 & 1.470703 \\ 6 & 0.745377 & 0.863352 & 1.507686 \\ 7 & 0.773513 & 0.879496 & 1.535878 \\ 8 & 0.796050 & 0.892216 & 1.558092 \\ 9 & 0.814508 & 0.902501 & 1.576052 \\ 10 & 0.829902 & 0.910989 & 1.590875\end{array}$

2. Componentes de Média ( BLUP Individual ) 
Selecao Individuos

\begin{tabular}{|c|c|c|c|c|}
\hline Ordem & Indiv & $\mathrm{u}+\mathrm{fp}$ & $\mathrm{G}$ & No \\
\hline 182 & 4.0876 & 14.8739 & 4.0876 & 14.8739 \\
\hline 240 & 3.0974 & 13.8837 & 3.5925 & 14.3788 \\
\hline 383 & 2.5033 & 13.2896 & 3.2295 & 14.0157 \\
\hline 4135 & 2.4043 & 13.1906 & 3.0232 & 13.8095 \\
\hline 574 & 2.2063 & 12.9926 & 2.8598 & 13.6461 \\
\hline 694 & 2.1073 & 12.8936 & 2.7344 & 13.5207 \\
\hline 7218 & 2.1073 & 12.8936 & 2.6448 & 13.4311 \\
\hline 816 & 1.8102 & 12.5965 & 2.5405 & 13.3268 \\
\hline 9100 & 1.8102 & 12.5965 & 2.4593 & 13.2456 \\
\hline 1028 & 1.7112 & 12.4975 & 2.3845 & 13.1708 \\
\hline 11145 & 1.7112 & 12.4975 & 2.3233 & 13.1096 \\
\hline 1244 & 1.5132 & 12.2995 & 2.2558 & 13.0421 \\
\hline 1354 & 1.5132 & 12.2995 & 2.1987 & 12.9850 \\
\hline 1427 & 1.3152 & 12.1014 & 2.1356 & 12.9219 \\
\hline 1549 & 1.3152 & 12.1014 & 2.0809 & 12.8672 \\
\hline 16171 & 1.0181 & 11.8044 & 2.0145 & 12.8007 \\
\hline 176 & 0.9191 & 11.7054 & 1.9500 & 12.7363 \\
\hline 188 & 0.9191 & 11.7054 & 1.8928 & 12.6790 \\
\hline 1962 & 0.9191 & 11.7054 & 1.8415 & 12.6278 \\
\hline 20176 & 0.9191 & 11.7054 & 1.7954 & 12.5817 \\
\hline 21194 & 0.9191 & 11.7054 & 1.7537 & 12.5399 \\
\hline 2214 & 0.7211 & 11.5073 & 1.7 & 12.4930 \\
\hline 23114 & 0.7211 & 11.5073 & 1.6639 & 12.4501 \\
\hline 24147 & 0.7211 & 11.5073 & 1.6 & 12.4109 \\
\hline 25165 & 0.7211 & 11.5073 & 1.5884 & 12.3747 \\
\hline 26220 & 0.7211 & 11.5073 & 1.5551 & 12.3414 \\
\hline 2746 & 0.5230 & 11.3093 & 1.5169 & 12.3031 \\
\hline 2860 & 0.5230 & 11.3093 & 1.4814 & 12.2676 \\
\hline 2990 & 0.5230 & 11.3093 & 1.4483 & 12.2346 \\
\hline 30110 & 0.5230 & 11.3 & 75 & 12.2038 \\
\hline 31132 & 0.5230 & 11.3 & 1.3886 & 12.1749 \\
\hline 32150 & & & & 12.1417 \\
\hline 33205 & 0.3250 & 11.1 & 1.3242 & 12.1104 \\
\hline 34219 & 0.3250 & 11.1113 & 1.2948 & 12.0810 \\
\hline 35193 & 0.1270 & 10.9 & 1.2614 & 12.0477 \\
\hline 36206 & 0.1270 & 10.9132 & 1.2299 & 12.0162 \\
\hline 375 & -0.1701 & 10.6162 & 1.1921 & 11.9783 \\
\hline 38213 & 1701 & 10.6 & 562 & 11.9425 \\
\hline 3973 & -0.2691 & 10.5172 & 1.1197 & 11.9059 \\
\hline 4078 & -0.2691 & 10.5172 & 1.0849 & 11.8712 \\
\hline 4180 & -0.2691 & 10.5172 & 1.0519 & 11.8382 \\
\hline 4289 & -0.2691 & 10.5172 & 1.0205 & 11.8067 \\
\hline 4396 & -0.2691 & 10.5172 & 0.9905 & 11.7768 \\
\hline 44121 & -0.2691 & 10.5172 & 0.9619 & 11.7481 \\
\hline 45146 & -0.2691 & 10.5172 & 0.9345 & 11.7208 \\
\hline 46181 & -0.2691 & 10.5172 & 0.9083 & 11.6946 \\
\hline 47108 & -0.3681 & 10.4182 & 0.8812 & 11.6675 \\
\hline 48221 & -0.3681 & 10.4182 & 0.8552 & 11.6414 \\
\hline 4984 & -0.4671 & 10.3192 & 0.8282 & 11.6144 \\
\hline 5098 & -0.4671 & 10.3192 & 0.8023 & 11.5885 \\
\hline 51144 & -0.4671 & 10.3192 & 0.7774 & 11.5636 \\
\hline 5224 & -0.6652 & 10.1211 & 0.7496 & 11.5359 \\
\hline 53140 & -0.6652 & 10.1211 & 0.7229 & 11.5092 \\
\hline 54178 & -0.6652 & 10.1211 & 0.6972 & 11.4835 \\
\hline 55216 & -0.6652 & 10.1211 & 0.6725 & 11.4587 \\
\hline 56226 & -0.6652 & 10.1211 & 0.6486 & 11.4348 \\
\hline 57190 & -0.7642 & 10.0221 & 0.6238 & 11.4101 \\
\hline
\end{tabular}




$\begin{array}{lllll}5850 & -0.8632 & 9.9231 & 0.5982 & 11.3844 \\ 59111 & -0.8632 & 9.9231 & 0.5734 & 11.3597 \\ 60112 & -0.8632 & 9.9231 & 0.5494 & 11.3357 \\ 61208 & -0.8632 & 9.9231 & 0.5263 & 11.3126 \\ 62209 & -0.8632 & 9.9231 & 0.5039 & 11.2901 \\ 637 & -0.9622 & 9.8241 & 0.4806 & 11.2669 \\ 64229 & -0.9622 & 9.8241 & 0.4581 & 11.2443 \\ 6517 & -1.0612 & 9.7251 & 0.4347 & 11.2210 \\ 66118 & -1.0612 & 9.7251 & 0.4120 & 11.1983 \\ 67154 & -1.0612 & 9.7251 & 0.3900 & 11.1763 \\ 68164 & -1.0612 & 9.7251 & 0.3687 & 11.1550 \\ 69183 & -1.0612 & 9.7251 & 0.3480 & 11.1342 \\ 70231 & -1.0612 & 9.7251 & 0.3278 & 11.1141 \\ 71236 & -1.0612 & 9.7251 & 0.3083 & 11.0945 \\ 7265 & -1.2592 & 9.5270 & 0.2865 & 11.0728 \\ 7388 & -1.2592 & 9.5270 & 0.2653 & 11.0516 \\ 74184 & -1.3583 & 9.4280 & 0.2434 & 11.0297 \\ 7518 & -1.4573 & 9.3290 & 0.2207 & 11.0070 \\ 7632 & -1.4573 & 9.3290 & 0.1986 & 10.9849 \\ 7768 & -1.4573 & 9.3290 & 0.1771 & 10.9634 \\ 78109 & -1.4573 & 9.3290 & 0.1562 & 10.9424 \\ 79202 & -1.4573 & 9.3290 & 0.1357 & 10.9220 \\ 80169 & -1.5563 & 9.2300 & 0.1146 & 10.9009 \\ 81225 & -1.5563 & 9.2300 & 0.0940 & 10.8802 \\ 82122 & -1.6553 & 9.1310 & 0.0726 & 10.8589 \\ 83191 & -1.7543 & 9.0320 & 0.0506 & 10.8369 \\ 84168 & -1.9524 & 8.8339 & 0.0268 & 10.8131 \\ 85238 & -2.2494 & 8.5369 & 0.0000 & 10.7863\end{array}$

\section{CAPÍTULO 2}

\section{Análise para o grupo Superprecoce}

$>$ \# Lendo o banco de dados

$>$ banco_SUPERprecoce<-read.table('C:/Users/rui/Documents/MATERIAL - Juaci/Dados Mateus/banco_geral-SUPERprecoce.txt', head=T)

$>$ Min_Forca

[1] 1.341667

$>$ Max_Forca

[1] 4.56

$>$ Dif_Forca

[1] 3.218333

> summary(MODEL_GERAL2)

Formula: Forca $\sim$ Dif_Forca/ $(1+\exp (-\mathrm{b} 0$ - b1 $*$ Dias $))+$ Min_Forca

Parameters:

Estimate Std. Error $\mathrm{t}$ value $\operatorname{Pr}(>|\mathrm{t}|)$

b0 $10.21241 \quad 0.68607 \quad 14.880 .000658 * * *$

b1 $-0.18234 \quad 0.01141-15.980 .000533 * * *$ 
$---$

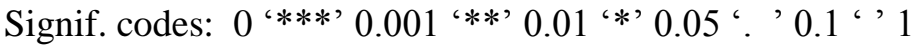

Residual standard error: 0.05298 on 3 degrees of freedom

Number of iterations to convergence: 8

Achieved convergence tolerance: $8.424 \mathrm{e}-07$

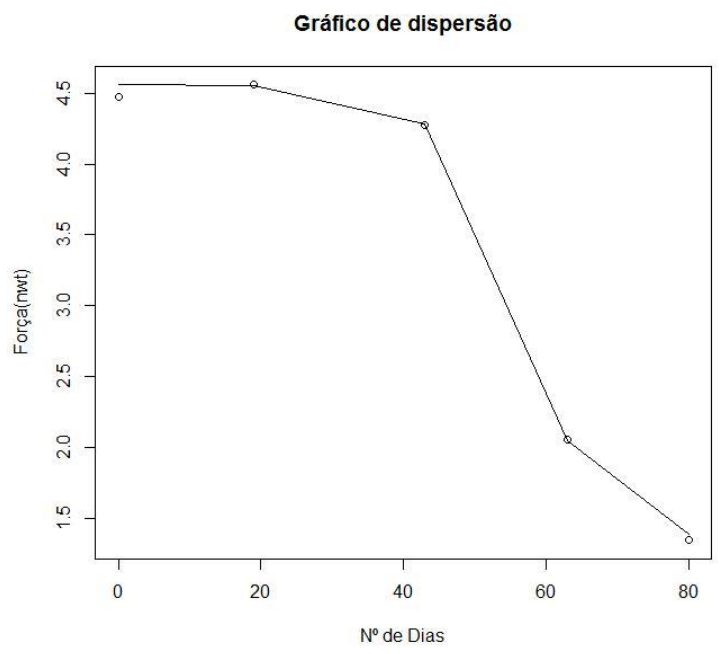

Análise para o grupo Precoce

> \# Lendo o banco de dados

> banco_NOVOprecoce<-read.table('C:/Users/rui/Documents/MATERIAL

Juaci/Dados Mateus/banco_geral-NOVOprecoce.txt', head=T)

$>$ Min_Forca

[1] 1.52082

$>$ Max_Forca

[1] 5.049385

$>$ Dif_Forca

[1] 3.528565

> summary(MODEL_GERAL2)

Formula: Forca Dif_Forca/(1 + exp $(-b 0$ - b1 * Dias $))+$ Min_Forca

Parameters:

Estimate Std. Error t value $\operatorname{Pr}(>|\mathrm{t}|)$

b0 11.164796 .032051 .8510 .161 b1 -

$0.182830 .09894-1.8480 .162$

Residual standard error: 0.4272 on 3 degrees of freedom

Number of iterations to convergence: 9

Achieved convergence tolerance: $9.032 \mathrm{e}-07$ 


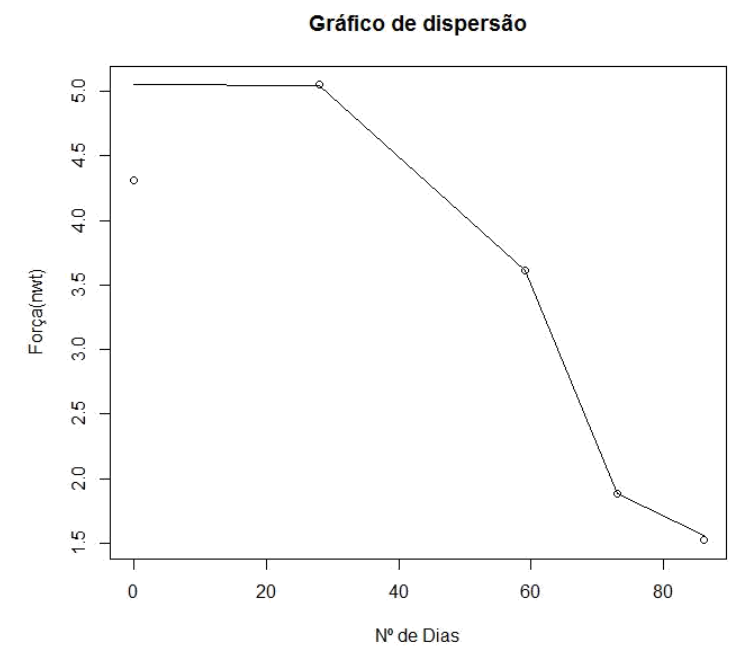

\section{Análise para o grupo Médio}

$>$ \# Lendo o banco de dados

> banco_MEDIO<-read.table('C:/Users/rui/Documents/MATERIAL

Juaci/Dados Mateus/banco_geral-MEDIO.txt', head=T)

$>$ Min_Forca

[1] 2.155655

$>$ Max_Forca

[1] 3.989866

$>$ Dif_Forca

[1] 1.834211

> summary(MODEL_GERAL2)

Formula: Forca $\sim$ Dif_Forca/ $(1+\exp (-\mathrm{b} 0$ - b1 $*$ Dias $))+$ Min_Forca

Parameters:

Estimate Std. Error $\mathrm{t}$ value $\operatorname{Pr}(>|\mathrm{t}|)$

b0 $3.93437 \quad 1.73308 \quad 2.270 \quad 0.0529$.

b1 $-0.05902 \quad 0.02455 \quad-2.404 \quad 0.0429 *$

$---$

Signif. codes: 0 ‘***’ 0.001 '**' 0.01 '*’ 0.05 ‘. ' 0.1 ' ' 1

Residual standard error: 0.3971 on 8 degrees of freedom

Number of iterations to convergence: 16

Achieved convergence tolerance: 4.976e-06 


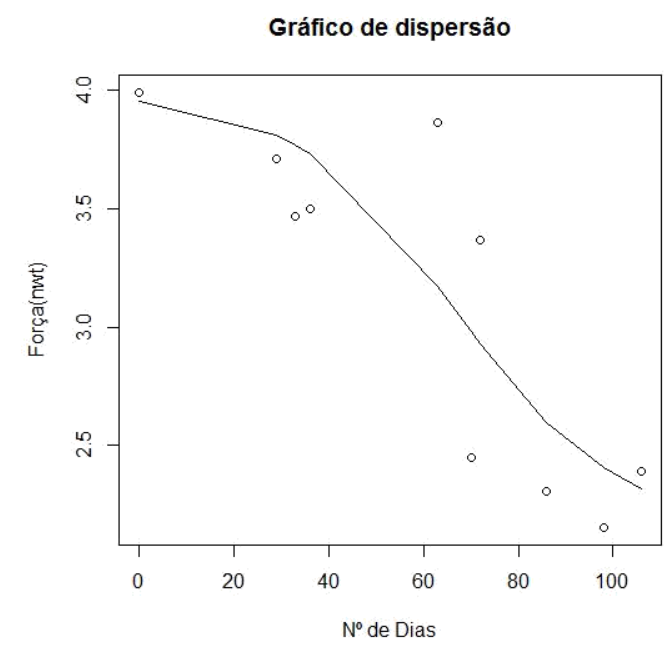

\section{Análise para o grupo Semitardio}

$>$ \# Lendo o banco de dados

> banco_SEMITARDIO<-read.table('C:/Users/rui/Documents/MATERIAL - Juaci/Dados Mateus/banco_geral-SEMITARDIO.txt', head=T)

$>$ Min_Forca

[1] 1.983333

> Max_Forca

[1] 4.833333

$>$ Dif_Forca

[1] 2.85

> summary(MODEL_GERAL2)

Formula: Forca $\sim$ Dif_Forca/ $(1+\exp (-\mathrm{b} 0$ - b1 $*$ Dias $))+$ Min_Forca

Parameters:

Estimate Std. Error t value $\operatorname{Pr}(>|t|)$

b0 $6.272912 .554372 .456 \quad 0.0494 *$

b1 $-0.08368 \quad 0.03291 \quad-2.543 \quad 0.0439 *$

Signif. codes: 0 ‘*** $0.001^{\prime * *}{ }^{* *} 0.01$ '*’ 0.05 '. ' 0.1 ' ' 1

Residual standard error: 0.4749 on 6 degrees of freedom

Number of iterations to convergence: 19

Achieved convergence tolerance: 9.107e-06 


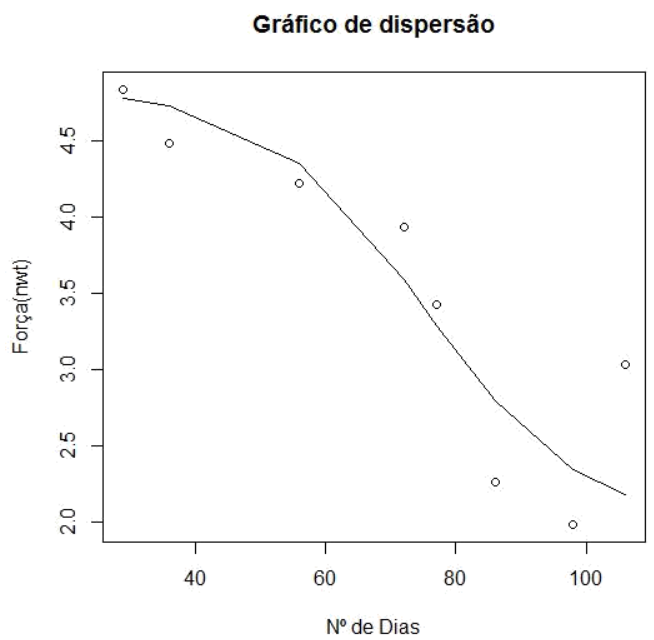

\section{CAPÍTULO 3}

\section{Análise para Cercosporiose:}

Arquivo analisado:

C: IUsersludo\Desktop\Pos Agronomia Peixoto\Doutorado\Mateus\CERCOSPORA FINAL (4).dbf

Variável analisada: SEV

Opção de transformação: Variável sem transformação ( Y )

TABELA DE ANÁLISE DE VARIÂNCIA

\begin{tabular}{|c|c|c|c|}
\hline $\mathrm{FV}$ & GL & SQ & $\mathrm{Fc} \operatorname{Pr}>\mathrm{Fc}$ \\
\hline GEN & 237 & 75.276724 & 2.8510 .0000 \\
\hline REP & 5 & 70.955669 & $14.191134 \quad 127.3640 .0000$ \\
\hline erro & 1185 & 132.034847 & 0.111422 \\
\hline Total corrigido & 1427 & 278.267241 & \\
\hline $\begin{array}{l}\mathrm{CV}(\%)= \\
\text { Média geral. }\end{array}$ & 111.5 & $\begin{array}{l}2 \\
93207\end{array}$ & observacões \\
\hline
\end{tabular}

Teste Scott-Knott (1974) para a FV GEN

NMS: 0,05

Média harmonica do número de repetições (r): 6 Erro padrão: 0,136272895421566 


\begin{tabular}{|c|c|}
\hline 40 & $0.000000 \mathrm{a} 1$ \\
\hline 168 & $0.000000 \mathrm{a} 1$ \\
\hline 224 & $0.000000 \mathrm{a} 1$ \\
\hline 217 & $0.000000 \mathrm{a} 1$ \\
\hline 39 & $0.000000 \mathrm{a} 1$ \\
\hline 185 & $0.000000 \mathrm{a} 1$ \\
\hline 162 & $0.021667 \mathrm{a} 1$ \\
\hline 145 & $0.021667 \mathrm{a} 1$ \\
\hline 129 & $0.021667 \mathrm{a} 1$ \\
\hline 49 & $0.021667 \mathrm{a} 1$ \\
\hline 135 & $0.021667 \mathrm{a} 1$ \\
\hline 147 & $0.041667 \mathrm{a} 1$ \\
\hline 208 & $0.041667 \mathrm{a} 1$ \\
\hline 220 & $0.041667 \mathrm{a} 1$ \\
\hline 177 & $0.041667 \mathrm{a} 1$ \\
\hline 73 & $0.041667 \mathrm{a} 1$ \\
\hline 223 & $0.041667 \mathrm{a} 1$ \\
\hline 161 & $0.041667 \mathrm{a} 1$ \\
\hline 213 & $0.041667 \mathrm{a} 1$ \\
\hline 4 & $0.041667 \mathrm{a} 1$ \\
\hline 123 & $0.043333 \mathrm{a} 1$ \\
\hline 227 & $0.043333 \mathrm{a} 1$ \\
\hline 222 & $0.043333 \mathrm{a} 1$ \\
\hline 180 & $0.043333 \mathrm{a} 1$ \\
\hline 122 & $0.063333 \mathrm{a} 1$ \\
\hline 13 & $0.063333 \mathrm{a} 1$ \\
\hline 209 & $0.063333 \mathrm{a} 1$ \\
\hline 207 & $0.063333 \mathrm{a} 1$ \\
\hline 203 & $0.063333 \mathrm{a} 1$ \\
\hline 198 & $0.063333 \mathrm{a} 1$ \\
\hline 170 & $0.063333 \mathrm{a} 1$ \\
\hline 225 & $0.063333 \mathrm{a} 1$ \\
\hline 210 & $0.063333 \mathrm{a} 1$ \\
\hline 94 & $0.063333 \mathrm{a} 1$ \\
\hline 133 & $0.063333 \mathrm{a} 1$ \\
\hline 169 & $0.063333 \mathrm{a} 1$ \\
\hline 95 & $0.083333 \mathrm{a} 1$ \\
\hline 214 & $0.083333 \mathrm{a} 1$ \\
\hline 153 & $0.085000 \mathrm{a} 1$ \\
\hline 192 & $0.085000 \mathrm{a} 1$ \\
\hline 183 & $0.085000 \mathrm{a} 1$ \\
\hline 196 & $0.085000 \mathrm{a} 1$ \\
\hline 204 & $0.085000 \mathrm{a} 1$ \\
\hline 197 & $0.085000 \mathrm{a} 1$ \\
\hline 212 & $0.085000 \mathrm{a} 1$ \\
\hline 172 & $0.085000 \mathrm{a} 1$ \\
\hline 63 & $0.085000 \mathrm{a} 1$ \\
\hline 134 & $0.105000 \mathrm{a} 1$ \\
\hline 231 & $0.105000 \mathrm{a} 1$ \\
\hline 69 & $0.105000 \mathrm{a} 1$ \\
\hline 157 & $0.105000 \mathrm{a} 1$ \\
\hline 234 & $0.105000 \mathrm{a} 1$ \\
\hline 159 & $0.105000 \mathrm{a} 1$ \\
\hline 179 & $0.105000 \mathrm{a} 1$ \\
\hline 41 & $0.105000 \mathrm{a} 1$ \\
\hline 166 & $0.105000 \mathrm{a} 1$ \\
\hline 200 & $0.105000 \mathrm{a} 1$ \\
\hline 149 & $0.105000 \mathrm{a} 1$ \\
\hline 176 & $0.106667 \mathrm{a} 1$ \\
\hline 148 & $0.106667 \mathrm{a} 1$ \\
\hline 195 & $0.125000 \mathrm{a} 1$ \\
\hline 194 & $0.125000 \mathrm{a} 1$ \\
\hline 164 & $0.125000 \mathrm{a} 1$ \\
\hline 106 & $0.126667 \mathrm{a} 1$ \\
\hline 53 & $0.126667 \mathrm{a} 1$ \\
\hline 124 & $0.126667 \mathrm{a} 1$ \\
\hline 146 & $0.126667 \mathrm{a} 1$ \\
\hline 229 & $0.146667 \mathrm{a} 1$ \\
\hline 184 & $0.146667 \mathrm{a} 1$ \\
\hline 31 & $0.146667 \mathrm{a} 1$ \\
\hline 92 & $0.146667 \mathrm{a} 1$ \\
\hline 37 & $0.146667 \mathrm{a} 1$ \\
\hline 89 & $0.146667 \mathrm{a} 1$ \\
\hline
\end{tabular}




\begin{tabular}{|c|c|}
\hline 105 & $0.148333 \mathrm{a} 1$ \\
\hline 84 & $0.148333 \mathrm{a} 1$ \\
\hline 191 & $0.148333 \mathrm{a} 1$ \\
\hline 151 & $0.166667 \mathrm{a} 1$ \\
\hline 59 & $0.166667 \mathrm{a} 1$ \\
\hline 216 & $0.168333 \mathrm{a} 1$ \\
\hline 190 & $0.168333 \mathrm{a} 1$ \\
\hline 188 & $0.168333 \mathrm{a} 1$ \\
\hline 187 & $0.168333 \mathrm{a} 1$ \\
\hline 128 & $0.168333 \mathrm{a} 1$ \\
\hline 160 & $0.168333 \mathrm{a} 1$ \\
\hline 34 & $0.168333 \mathrm{a} 1$ \\
\hline 150 & $0.168333 \mathrm{a} 1$ \\
\hline 131 & $0.168333 \mathrm{a} 1$ \\
\hline 136 & $0.168333 \mathrm{a} 1$ \\
\hline 70 & $0.188333 \mathrm{a} 1$ \\
\hline 193 & $0.188333 \mathrm{a} 1$ \\
\hline 238 & $0.188333 \mathrm{a} 1$ \\
\hline 137 & $0.190000 \mathrm{a} 1$ \\
\hline 140 & $0.190000 \mathrm{a} 1$ \\
\hline 126 & $0.210000 \mathrm{a} 1$ \\
\hline 120 & $0.210000 \mathrm{a} 1$ \\
\hline 26 & $0.210000 \mathrm{a} 1$ \\
\hline 102 & $0.210000 \mathrm{a} 1$ \\
\hline 156 & $0.210000 \mathrm{a} 1$ \\
\hline 226 & $0.210000 \mathrm{a} 1$ \\
\hline 218 & $0.210000 \mathrm{a} 1$ \\
\hline 121 & $0.210000 \mathrm{a} 1$ \\
\hline 182 & $0.211667 \mathrm{a} 1$ \\
\hline 175 & $0.211667 \mathrm{a} 1$ \\
\hline 19 & $0.230000 \mathrm{a} 1$ \\
\hline 115 & $0.230000 \mathrm{a} 1$ \\
\hline 186 & $0.230000 \mathrm{a} 1$ \\
\hline 107 & $0.230000 \mathrm{a} 1$ \\
\hline 237 & $0.230000 \mathrm{a} 1$ \\
\hline 91 & $0.230000 \mathrm{a} 1$ \\
\hline 181 & $0.231667 \mathrm{a} 1$ \\
\hline 7 & $0.231667 \mathrm{a} 1$ \\
\hline 155 & $0.231667 \mathrm{a} 1$ \\
\hline 3 & $0.231667 \mathrm{a} 1$ \\
\hline 163 & $0.231667 \mathrm{a} 1$ \\
\hline 154 & $0.250000 \mathrm{a} 1$ \\
\hline 171 & $0.250000 \mathrm{a} 1$ \\
\hline 25 & $0.251667 \mathrm{a} 1$ \\
\hline 1 & $0.251667 \mathrm{a} 1$ \\
\hline 111 & $0.251667 \mathrm{a} 1$ \\
\hline 141 & $0.251667 \mathrm{a} 1$ \\
\hline 110 & $0.251667 \mathrm{a} 1$ \\
\hline 103 & $0.251667 \mathrm{a} 1$ \\
\hline 233 & $0.251667 \mathrm{a} 1$ \\
\hline 199 & $0.251667 \mathrm{a} 1$ \\
\hline 100 & $0.253333 \mathrm{a} 1$ \\
\hline 178 & $0.271667 \mathrm{a} 1$ \\
\hline 215 & $0.271667 \mathrm{a} 1$ \\
\hline 12 & $0.271667 \mathrm{a} 1$ \\
\hline 118 & $0.271667 \mathrm{a} 1$ \\
\hline 189 & $0.271667 \mathrm{a} 1$ \\
\hline 125 & $0.271667 \mathrm{a} 1$ \\
\hline 221 & $0.273333 \mathrm{a} 1$ \\
\hline 47 & $0.293333 \mathrm{a} 1$ \\
\hline 18 & $0.293333 \mathrm{a} 1$ \\
\hline 62 & $0.293333 \mathrm{a} 1$ \\
\hline 130 & $0.313333 \mathrm{a} 1$ \\
\hline 132 & $0.313333 \mathrm{a} 1$ \\
\hline 211 & 0.313333 a 1 \\
\hline 113 & $0.313333 \mathrm{a} 1$ \\
\hline 65 & $0.315000 \mathrm{a} 1$ \\
\hline 236 & $0.315000 \mathrm{a} 1$ \\
\hline 28 & $0.315000 \mathrm{a} 1$ \\
\hline 38 & $0.315000 \mathrm{a} 1$ \\
\hline 144 & $0.315000 \mathrm{a} 1$ \\
\hline 58 & $0.315000 \mathrm{a} 1$ \\
\hline 67 & $0.333333 \mathrm{a} 1$ \\
\hline 9 & $0.333333 \mathrm{a} 1$ \\
\hline
\end{tabular}




\begin{tabular}{|c|c|}
\hline 56 & $0.335000 \mathrm{a} 1$ \\
\hline 48 & $0.335000 \mathrm{a} 1$ \\
\hline 96 & $0.335000 \mathrm{a} 1$ \\
\hline 108 & $0.335000 \mathrm{a} 1$ \\
\hline 93 & $0.335000 \mathrm{a} 1$ \\
\hline 104 & $0.336667 \mathrm{a} 1$ \\
\hline 152 & $0.336667 \mathrm{a} 1$ \\
\hline 10 & $0.355000 \mathrm{a} 1$ \\
\hline 117 & $0.355000 \mathrm{a} 1$ \\
\hline 139 & $0.355000 \mathrm{a} 1$ \\
\hline 101 & $0.355000 \mathrm{a} 1$ \\
\hline 55 & $0.355000 \mathrm{a} 1$ \\
\hline 165 & $0.355000 \mathrm{a} 1$ \\
\hline 5 & $0.356667 \mathrm{a} 1$ \\
\hline 74 & $0.356667 \mathrm{a} 1$ \\
\hline 143 & $0.356667 \mathrm{a} 1$ \\
\hline 45 & $0.356667 \mathrm{a} 1$ \\
\hline 54 & $0.375000 \mathrm{a} 1$ \\
\hline 24 & $0.376667 \mathrm{a} 1$ \\
\hline 14 & $0.376667 \mathrm{a} 1$ \\
\hline 16 & $0.376667 \mathrm{a} 1$ \\
\hline 88 & $0.376667 \mathrm{a} 1$ \\
\hline 79 & $0.376667 \mathrm{a} 1$ \\
\hline 230 & $0.376667 \mathrm{a} 1$ \\
\hline 2 & $0.378333 \mathrm{a} 1$ \\
\hline 66 & $0.396667 \mathrm{a} 1$ \\
\hline 232 & $0.396667 \mathrm{a} 1$ \\
\hline 60 & $0.396667 \mathrm{a} 1$ \\
\hline 206 & $0.398333 \mathrm{a} 1$ \\
\hline 81 & $0.398333 \mathrm{a} 1$ \\
\hline 174 & $0.398333 \mathrm{a} 1$ \\
\hline 205 & $0.398333 \mathrm{a} 1$ \\
\hline 27 & $0.418333 \mathrm{a} 2$ \\
\hline 167 & $0.421667 \mathrm{a} 2$ \\
\hline 201 & $0.438333 \mathrm{a} 2$ \\
\hline 22 & $0.438333 \mathrm{a} 2$ \\
\hline 23 & $0.441667 \mathrm{a} 2$ \\
\hline 112 & $0.458333 \mathrm{a} 2$ \\
\hline 50 & $0.458333 \mathrm{a} 2$ \\
\hline 33 & $0.460000 \mathrm{a} 2$ \\
\hline 98 & $0.460000 \mathrm{a} 2$ \\
\hline 36 & $0.460000 \mathrm{a} 2$ \\
\hline 44 & $0.460000 \mathrm{a} 2$ \\
\hline 43 & $0.480000 \mathrm{a} 2$ \\
\hline 138 & $0.480000 \mathrm{a} 2$ \\
\hline 219 & $0.481667 \mathrm{a} 2$ \\
\hline 85 & $0.481667 \mathrm{a} 2$ \\
\hline 20 & $0.481667 \mathrm{a} 2$ \\
\hline 32 & $0.501667 \mathrm{a} 2$ \\
\hline 35 & $0.501667 \mathrm{a} 2$ \\
\hline 116 & $0.501667 \mathrm{a} 2$ \\
\hline 97 & $0.501667 \mathrm{a} 2$ \\
\hline 46 & $0.523333 \mathrm{a} 2$ \\
\hline 235 & $0.523333 \mathrm{a} 2$ \\
\hline 99 & $0.523333 \mathrm{a} 2$ \\
\hline 6 & $0.541667 \mathrm{a} 2$ \\
\hline 61 & $0.543333 \mathrm{a} 2$ \\
\hline 114 & $0.543333 \mathrm{a} 2$ \\
\hline 228 & $0.543333 \mathrm{a} 2$ \\
\hline 87 & $0.543333 \mathrm{a} 2$ \\
\hline 75 & $0.543333 \mathrm{a} 2$ \\
\hline 86 & $0.563333 \mathrm{a} 2$ \\
\hline 30 & $0.565000 \mathrm{a} 2$ \\
\hline 29 & $0.585000 \mathrm{a} 2$ \\
\hline 119 & $0.585000 \mathrm{a} 2$ \\
\hline 90 & $0.585000 \mathrm{a} 2$ \\
\hline 64 & $0.585000 \mathrm{a} 2$ \\
\hline 158 & $0.585000 \mathrm{a} 2$ \\
\hline 8 & $0.605000 \mathrm{a} 2$ \\
\hline 173 & $0.628333 \mathrm{a} 2$ \\
\hline 72 & $0.646667 \mathrm{a} 2$ \\
\hline 80 & $0.666667 \mathrm{a} 2$ \\
\hline 77 & $0.670000 \mathrm{a} 2$ \\
\hline 83 & $0.671667 \mathrm{a} 2$ \\
\hline
\end{tabular}




$\begin{array}{lr}52 & 0.688333 \mathrm{a} 2 \\ 109 & 0.690000 \mathrm{a} 2 \\ 142 & 0.691667 \mathrm{a} 2 \\ 15 & 0.730000 \mathrm{a} 3 \\ 127 & 0.731667 \mathrm{a} 3 \\ 42 & 0.751667 \mathrm{a} 3 \\ 21 & 0.751667 \mathrm{a} 3 \\ 71 & 0.753333 \mathrm{a} 3 \\ 76 & 0.815000 \mathrm{a} 3 \\ 202 & 0.815000 \mathrm{a} 3 \\ 68 & 0.855000 \mathrm{a} 3 \\ 51 & 0.918333 \mathrm{a} 3 \\ 78 & 0.940000 \mathrm{a} 3 \\ 17 & 0.980000 \mathrm{a} 3 \\ 57 & 1.023333 \mathrm{a} 3 \\ 11 & 1.146667 \mathrm{a} 3 \\ 82 & 1.271667 \mathrm{a} 3 \\ ----------------------------------------------------\end{array}$

Variável analisada: SEV

Opção de transformação: Raiz quadrada de $\mathrm{Y}+1.0$-SQRT $(\mathrm{Y}+1.0)$

TABELA DE ANÁLISE DE VARIÂNCIA

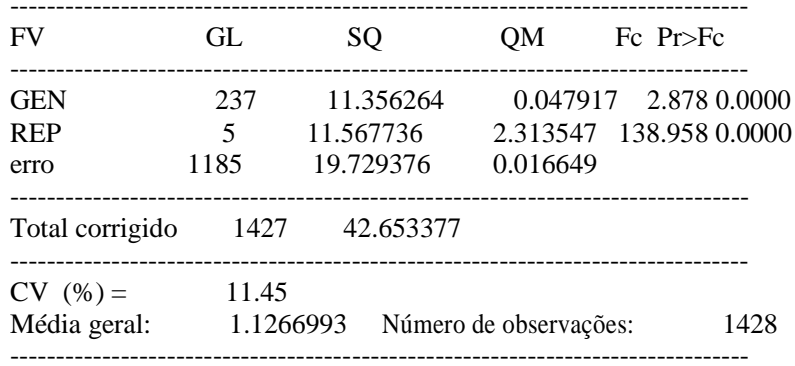

Teste Scott-Knott (1974) para a FV GEN

NMS: 0,05

Média harmonica do número de repetições (r): 6 Erro padrão: 0,0526771020004909

\begin{tabular}{lr} 
Tratamentos & Médias Resultados do teste \\
\hline 224 & $1.000000 \mathrm{a} 1$ \\
217 & $1.000000 \mathrm{a} 1$ \\
168 & $1.000000 \mathrm{a} 1$ \\
39 & $1.000000 \mathrm{a} 1$ \\
40 & $1.000000 \mathrm{a} 1$ \\
185 & $1.000000 \mathrm{a} 1$ \\
49 & $1.010502 \mathrm{a} 1$ \\
135 & $1.010502 \mathrm{a} 1$ \\
129 & $1.010502 \mathrm{a} 1$ \\
162 & $1.010502 \mathrm{a} 1$ \\
145 & $1.010502 \mathrm{a} 1$ \\
147 & $1.019672 \mathrm{a} 1$
\end{tabular}




\begin{tabular}{|c|c|}
\hline 223 & $1.019672 \mathrm{a} 1$ \\
\hline 213 & $1.019672 \mathrm{a} 1$ \\
\hline 161 & $1.019672 \mathrm{a} 1$ \\
\hline 177 & $1.019672 \mathrm{a} 1$ \\
\hline 73 & $1.019672 \mathrm{a} 1$ \\
\hline 220 & $1.019672 \mathrm{a} 1$ \\
\hline 208 & $1.019672 \mathrm{a} 1$ \\
\hline 4 & $1.019672 \mathrm{a} 1$ \\
\hline 180 & $1.021005 \mathrm{a} 1$ \\
\hline 222 & $1.021005 \mathrm{a} 1$ \\
\hline 123 & $1.021005 \mathrm{a} 1$ \\
\hline 227 & $1.021005 \mathrm{a} 1$ \\
\hline 209 & $1.029122 \mathrm{a} 1$ \\
\hline 210 & $1.029122 \mathrm{a} 1$ \\
\hline 225 & $1.029122 \mathrm{a} 1$ \\
\hline 207 & $1.029122 \mathrm{a} 1$ \\
\hline 122 & $1.029122 \mathrm{a} 1$ \\
\hline 133 & $1.030175 \mathrm{a} 1$ \\
\hline 169 & $1.030175 \mathrm{a} 1$ \\
\hline 198 & $1.030175 \mathrm{a} 1$ \\
\hline 13 & $1.030175 \mathrm{a} 1$ \\
\hline 94 & $1.030175 \mathrm{a} 1$ \\
\hline 170 & $1.030175 \mathrm{a} 1$ \\
\hline 203 & $1.030175 \mathrm{a} 1$ \\
\hline 95 & $1.037457 \mathrm{a} 1$ \\
\hline 214 & $1.039345 \mathrm{a} 1$ \\
\hline 63 & $1.039625 \mathrm{a} 1$ \\
\hline 212 & $1.039625 \mathrm{a} 1$ \\
\hline 172 & $1.039625 \mathrm{a} 1$ \\
\hline 192 & $1.039625 \mathrm{a} 1$ \\
\hline 196 & $1.039625 \mathrm{a} 1$ \\
\hline 197 & $1.039625 \mathrm{a} 1$ \\
\hline 183 & $1.040677 \mathrm{a} 1$ \\
\hline 204 & $1.040677 \mathrm{a} 1$ \\
\hline 153 & $1.040677 \mathrm{a} 1$ \\
\hline 159 & $1.047960 \mathrm{a} 1$ \\
\hline 166 & $1.047960 \mathrm{a} 1$ \\
\hline 157 & $1.047960 \mathrm{a} 1$ \\
\hline 200 & $1.047960 \mathrm{a} 1$ \\
\hline 231 & $1.047960 \mathrm{a} 1$ \\
\hline 149 & $1.047960 \mathrm{a} 1$ \\
\hline 179 & $1.048795 \mathrm{a} 1$ \\
\hline 69 & $1.048795 \mathrm{a} 1$ \\
\hline 41 & $1.048795 \mathrm{a} 1$ \\
\hline 134 & $1.049847 \mathrm{a} 1$ \\
\hline 234 & $1.049847 \mathrm{a} 1$ \\
\hline 176 & $1.050127 \mathrm{a} 1$ \\
\hline 148 & $1.050127 \mathrm{a} 1$ \\
\hline 195 & $1.057130 \mathrm{a} 1$ \\
\hline 106 & $1.058462 \mathrm{a} 1$ \\
\hline 194 & $1.059017 \mathrm{a} 1$ \\
\hline 164 & $1.059017 \mathrm{a} 1$ \\
\hline 53 & $1.059297 \mathrm{a} 1$ \\
\hline 146 & $1.059297 \mathrm{a} 1$ \\
\hline 124 & $1.059297 \mathrm{a} 1$ \\
\hline 229 & $1.064315 \mathrm{a} 1$ \\
\hline 37 & $1.065791 \mathrm{a} 1$ \\
\hline 31 & $1.066580 \mathrm{a} 1$ \\
\hline 92 & $1.067632 \mathrm{a} 1$ \\
\hline 184 & $1.067632 \mathrm{a} 1$ \\
\hline 89 & $1.067632 \mathrm{a} 1$ \\
\hline 191 & $1.068747 \mathrm{a} 1$ \\
\hline 105 & $1.069800 \mathrm{a} 1$ \\
\hline 84 & $1.069800 \mathrm{a} 1$ \\
\hline 131 & $1.074817 \mathrm{a} 1$ \\
\hline 136 & $1.074817 \mathrm{a} 1$ \\
\hline 188 & $1.075241 \mathrm{a} 1$ \\
\hline 128 & $1.076294 \mathrm{a} 1$ \\
\hline 151 & $1.076802 \mathrm{a} 1$ \\
\hline 59 & $1.076802 \mathrm{a} 1$ \\
\hline 34 & $1.077082 \mathrm{a} 1$ \\
\hline 190 & $1.077082 \mathrm{a} 1$ \\
\hline 160 & $1.077082 \mathrm{a} 1$ \\
\hline 187 & $1.078135 \mathrm{a} 1$ \\
\hline
\end{tabular}




\begin{tabular}{|c|c|}
\hline 150 & $1.078135 \mathrm{a} 1$ \\
\hline 216 & $1.078969 \mathrm{a} 1$ \\
\hline 70 & $1.079538 \mathrm{a} 1$ \\
\hline 193 & $1.085417 \mathrm{a} 1$ \\
\hline 238 & $1.085464 \mathrm{a} 1$ \\
\hline 137 & $1.089472 \mathrm{a} 1$ \\
\hline 140 & $1.089472 \mathrm{a} 1$ \\
\hline 120 & $1.094490 \mathrm{a} 1$ \\
\hline 126 & $1.094490 \mathrm{a} 1$ \\
\hline 218 & $1.094490 \mathrm{a} 1$ \\
\hline 226 & $1.095702 \mathrm{a} 1$ \\
\hline 102 & $1.095702 \mathrm{a} 1$ \\
\hline 26 & $1.095966 \mathrm{a} 1$ \\
\hline 121 & $1.096755 \mathrm{a} 1$ \\
\hline 156 & $1.097589 \mathrm{a} 1$ \\
\hline 182 & $1.098922 \mathrm{a} 1$ \\
\hline 175 & $1.098922 \mathrm{a} 1$ \\
\hline 91 & $1.101200 \mathrm{a} 1$ \\
\hline 237 & $1.101200 \mathrm{a} 1$ \\
\hline 19 & $1.101773 \mathrm{a} 1$ \\
\hline 107 & $1.103249 \mathrm{a} 1$ \\
\hline 186 & $1.103249 \mathrm{a} 1$ \\
\hline 3 & $1.103940 \mathrm{a} 1$ \\
\hline 163 & $1.104364 \mathrm{a} 1$ \\
\hline 115 & $1.105136 \mathrm{a} 1$ \\
\hline 7 & $1.105416 \mathrm{a} 1$ \\
\hline 181 & $1.105416 \mathrm{a} 1$ \\
\hline 25 & $1.106750 \mathrm{a} 1$ \\
\hline 1 & $1.106750 \mathrm{a} 1$ \\
\hline 155 & $1.107257 \mathrm{a} 1$ \\
\hline 171 & $1.108380 \mathrm{a} 1$ \\
\hline 110 & $1.110434 \mathrm{a} 1$ \\
\hline 199 & $1.110650 \mathrm{a} 1$ \\
\hline 111 & $1.112699 \mathrm{a} 1$ \\
\hline 233 & $1.112699 \mathrm{a} 1$ \\
\hline 154 & $1.112830 \mathrm{a} 1$ \\
\hline 141 & $1.113751 \mathrm{a} 1$ \\
\hline 103 & $1.114586 \mathrm{a} 1$ \\
\hline 221 & $1.116200 \mathrm{a} 1$ \\
\hline 100 & $1.117759 \mathrm{a} 1$ \\
\hline 118 & $1.118128 \mathrm{a} 1$ \\
\hline 215 & $1.120392 \mathrm{a} 1$ \\
\hline 12 & $1.120392 \mathrm{a} 1$ \\
\hline 47 & $1.120629 \mathrm{a} 1$ \\
\hline 189 & $1.121034 \mathrm{a} 1$ \\
\hline 125 & $1.122921 \mathrm{a} 1$ \\
\hline 18 & $1.122958 \mathrm{a} 1$ \\
\hline 178 & $1.123710 \mathrm{a} 1$ \\
\hline 62 & $1.129696 \mathrm{a} 1$ \\
\hline 130 & $1.132128 \mathrm{a} 1$ \\
\hline 113 & $1.134827 \mathrm{a} 1$ \\
\hline 65 & $1.135872 \mathrm{a} 1$ \\
\hline 67 & $1.136201 \mathrm{a} 1$ \\
\hline 48 & $1.136573 \mathrm{a} 1$ \\
\hline 132 & $1.136668 \mathrm{a} 1$ \\
\hline 211 & $1.136770 \mathrm{a} 1$ \\
\hline 236 & $1.137097 \mathrm{a} 1$ \\
\hline 96 & $1.139249 \mathrm{a} 1$ \\
\hline 58 & $1.139556 \mathrm{a} 1$ \\
\hline 28 & $1.140825 \mathrm{a} 1$ \\
\hline 108 & $1.141578 \mathrm{a} 1$ \\
\hline 38 & $1.141821 \mathrm{a} 1$ \\
\hline 93 & $1.142630 \mathrm{a} 1$ \\
\hline 55 & $1.142976 \mathrm{a} 1$ \\
\hline 144 & $1.143926 \mathrm{a} 1$ \\
\hline 56 & $1.144208 \mathrm{a} 1$ \\
\hline 9 & $1.145083 \mathrm{a} 1$ \\
\hline 117 & $1.147584 \mathrm{a} 1$ \\
\hline 10 & $1.147584 \mathrm{a} 1$ \\
\hline 152 & $1.147599 \mathrm{a} 1$ \\
\hline 104 & $1.149222 \mathrm{a} 1$ \\
\hline 143 & $1.152833 \mathrm{a} 2$ \\
\hline 139 & $1.153125 \mathrm{a} 2$ \\
\hline 24 & $1.153151 \mathrm{a} 2$ \\
\hline
\end{tabular}




\begin{tabular}{|c|c|}
\hline 2 & $1.153748 \mathrm{a} 2$ \\
\hline 5 & $1.155293 \mathrm{a} 2$ \\
\hline 74 & $1.155934 \mathrm{a} 2$ \\
\hline 165 & $1.156420 \mathrm{a} 2$ \\
\hline 66 & $1.157434 \mathrm{a} 2$ \\
\hline 45 & $1.157557 \mathrm{a} 2$ \\
\hline 16 & $1.158103 \mathrm{a} 2$ \\
\hline 54 & $1.158248 \mathrm{a} 2$ \\
\hline 79 & $1.160013 \mathrm{a} 2$ \\
\hline 14 & $1.162039 \mathrm{a} 2$ \\
\hline 101 & $1.162220 \mathrm{a} 2$ \\
\hline 232 & $1.164489 \mathrm{a} 2$ \\
\hline 88 & $1.165104 \mathrm{a} 2$ \\
\hline 230 & $1.170617 \mathrm{a} 2$ \\
\hline 60 & $1.172284 \mathrm{a} 2$ \\
\hline 174 & $1.172289 \mathrm{a} 2$ \\
\hline 81 & $1.173766 \mathrm{a} 2$ \\
\hline 206 & $1.174554 \mathrm{a} 2$ \\
\hline 205 & $1.174965 \mathrm{a} 2$ \\
\hline 27 & $1.178851 \mathrm{a} 2$ \\
\hline 201 & $1.184703 \mathrm{a} 2$ \\
\hline 112 & $1.186521 \mathrm{a} 2$ \\
\hline 23 & $1.186700 \mathrm{a} 2$ \\
\hline 44 & $1.186801 \mathrm{a} 2$ \\
\hline 22 & $1.186866 \mathrm{a} 2$ \\
\hline 167 & $1.190108 \mathrm{a} 2$ \\
\hline 36 & $1.193767 \mathrm{a} 2$ \\
\hline 33 & $1.194406 \mathrm{a} 2$ \\
\hline 50 & $1.197763 \mathrm{a} 2$ \\
\hline 219 & $1.198535 \mathrm{a} 2$ \\
\hline 85 & $1.199115 \mathrm{a} 2$ \\
\hline 98 & $1.199497 \mathrm{a} 2$ \\
\hline 138 & $1.202386 \mathrm{a} 2$ \\
\hline 43 & $1.204651 \mathrm{a} 2$ \\
\hline 32 & $1.205609 \mathrm{a} 2$ \\
\hline 116 & $1.206291 \mathrm{a} 2$ \\
\hline 97 & $1.206672 \mathrm{a} 2$ \\
\hline 46 & $1.207154 \mathrm{a} 2$ \\
\hline 20 & $1.207185 \mathrm{a} 2$ \\
\hline 99 & $1.211199 \mathrm{a} 2$ \\
\hline 35 & $1.212191 \mathrm{a} 2$ \\
\hline 114 & $1.215416 \mathrm{a} 2$ \\
\hline 235 & $1.219508 \mathrm{a} 2$ \\
\hline 75 & $1.220153 \mathrm{a} 2$ \\
\hline 228 & $1.221764 \mathrm{a} 2$ \\
\hline 61 & $1.227138 \mathrm{a} 2$ \\
\hline 86 & $1.227747 \mathrm{a} 2$ \\
\hline 87 & $1.229598 \mathrm{a} 2$ \\
\hline 119 & $1.231844 \mathrm{a} 2$ \\
\hline 29 & $1.235780 \mathrm{a} 2$ \\
\hline 30 & $1.236297 \mathrm{a} 2$ \\
\hline 6 & $1.236353 \mathrm{a} 2$ \\
\hline 64 & $1.238250 \mathrm{a} 2$ \\
\hline 90 & $1.239447 \mathrm{a} 2$ \\
\hline 158 & $1.242186 \mathrm{a} 2$ \\
\hline 8 & $1.252021 \mathrm{a} 2$ \\
\hline 72 & $1.256765 \mathrm{a} 2$ \\
\hline 80 & $1.263523 \mathrm{a} 3$ \\
\hline 77 & $1.269317 \mathrm{a} 3$ \\
\hline 52 & $1.272590 \mathrm{a} 3$ \\
\hline 173 & $1.273844 \mathrm{a} 3$ \\
\hline 15 & $1.277266 \mathrm{a} 3$ \\
\hline 83 & $1.287290 \mathrm{a} 3$ \\
\hline 109 & $1.290401 \mathrm{a} 3$ \\
\hline 142 & $1.291066 \mathrm{a} 3$ \\
\hline 71 & $1.292615 \mathrm{a} 3$ \\
\hline 42 & $1.296421 \mathrm{a} 3$ \\
\hline 127 & $1.297192 \mathrm{a} 3$ \\
\hline 76 & $1.306827 \mathrm{a} 3$ \\
\hline 21 & $1.313619 \mathrm{a} 3$ \\
\hline 68 & $1.315805 \mathrm{a} 3$ \\
\hline 202 & $1.337562 \mathrm{a} 3$ \\
\hline 51 & $1.355919 \mathrm{a} 3$ \\
\hline 78 & $1.364879 \mathrm{a} 3$ \\
\hline
\end{tabular}




$\begin{array}{ll}17 & 1.376083 \mathrm{a} 3 \\ 57 & 1.395980 \mathrm{a} 3 \\ 11 & 1.406287 \mathrm{a} 3 \\ 82 & 1.468824 \mathrm{a} 3\end{array}$

\section{Análise para Ferrugem}

Arquivo analisado:

C:IUsersludo\Desktop\Pos Agronomia Peixoto\DoutoradolMateus\FERRUGEM FINAL (2).dbf

Variável analisada: SEV

Opção de transformação: Variável sem transformação ( Y )

TABELA DE ANÁLISE DE VARIÂNCIA

\begin{tabular}{|c|c|c|c|c|}
\hline FV & GL & SQ & QM & $\mathrm{Fc} \operatorname{Pr}>\mathrm{Fc}$ \\
\hline GEN & 237 & 96.682948 & 0.407945 & 3.3840 .0000 \\
\hline REP_1 & 5 & 9.847911 & 1.969582 & 16.3360 .0000 \\
\hline erro & 1185 & 142.872223 & 0.120567 & \\
\hline \multicolumn{2}{|c|}{ Total corrigido1427 } & 249.4030 & & \\
\hline $\begin{array}{l}\mathrm{CV}(\%)= \\
\text { Média geral: }\end{array}$ & $\begin{array}{l}125 \\
0.2\end{array}$ & $\begin{array}{l}6 \\
6583\end{array}$ & observaçõe & 1428 \\
\hline
\end{tabular}

Teste Scott-Knott (1974) para a FV GEN

NMS: 0,05

Média harmonica do número de repetições (r): 6 Erro padrão: 0,141755233019729

\begin{tabular}{lc} 
Tratamentos & Médias \\
\hline 140 & $0.000000 \mathrm{a} 1$ \\
135 & $0.000000 \mathrm{a} 1$ \\
133 & $0.000000 \mathrm{a} 1$ \\
180 & $0.000000 \mathrm{a} 1$ \\
220 & $0.000000 \mathrm{a} 1$ \\
146 & $0.000000 \mathrm{a} 1$ \\
100 & $0.000000 \mathrm{a} 1$ \\
123 & $0.000000 \mathrm{a} 1$ \\
122 & $0.000000 \mathrm{a} 1$ \\
129 & $0.000000 \mathrm{a} 1$ \\
216 & $0.000000 \mathrm{a} 1$ \\
36 & $0.021667 \mathrm{a} 1$ \\
39 & $0.021667 \mathrm{a} 1$ \\
137 & $0.021667 \mathrm{a} 1$ \\
59 & $0.021667 \mathrm{a} 1$ \\
145 & $0.021667 \mathrm{a} 1$ \\
196 & $0.021667 \mathrm{a} 1$ \\
150 & $0.041667 \mathrm{a} 1$ \\
157 & $0.041667 \mathrm{a} 1$
\end{tabular}




\begin{tabular}{|c|c|}
\hline 93 & $0.041667 \mathrm{a} 1$ \\
\hline 159 & $0.041667 \mathrm{a} 1$ \\
\hline 40 & $0.041667 \mathrm{a} 1$ \\
\hline 60 & $0.041667 \mathrm{a} 1$ \\
\hline 210 & $0.041667 \mathrm{a} 1$ \\
\hline 192 & $0.041667 \mathrm{a} 1$ \\
\hline 53 & $0.041667 \mathrm{a} 1$ \\
\hline 73 & $0.043333 \mathrm{a} 1$ \\
\hline 94 & $0.043333 \mathrm{a} 1$ \\
\hline 185 & $0.043333 \mathrm{a} 1$ \\
\hline 149 & $0.063333 \mathrm{a} 1$ \\
\hline 179 & $0.063333 \mathrm{a} 1$ \\
\hline 177 & $0.063333 \mathrm{a} 1$ \\
\hline 132 & $0.063333 \mathrm{a} 1$ \\
\hline 203 & $0.063333 \mathrm{a} 1$ \\
\hline 110 & $0.063333 \mathrm{a} 1$ \\
\hline 224 & $0.063333 \mathrm{a} 1$ \\
\hline 98 & $0.083333 \mathrm{a} 1$ \\
\hline 1 & $0.083333 \mathrm{a} 1$ \\
\hline 125 & $0.083333 \mathrm{a} 1$ \\
\hline 92 & $0.083333 \mathrm{a} 1$ \\
\hline 212 & $0.083333 \mathrm{a} 1$ \\
\hline 182 & $0.083333 \mathrm{a} 1$ \\
\hline 49 & $0.085000 \mathrm{a} 1$ \\
\hline 130 & $0.085000 \mathrm{a} 1$ \\
\hline 124 & $0.085000 \mathrm{a} 1$ \\
\hline 131 & $0.085000 \mathrm{a} 1$ \\
\hline 183 & $0.085000 \mathrm{a} 1$ \\
\hline 35 & $0.085000 \mathrm{a} 1$ \\
\hline 172 & $0.085000 \mathrm{a} 1$ \\
\hline 166 & $0.085000 \mathrm{a} 1$ \\
\hline 194 & $0.085000 \mathrm{a} 1$ \\
\hline 170 & $0.105000 \mathrm{a} 1$ \\
\hline 85 & $0.105000 \mathrm{a} 1$ \\
\hline 153 & $0.105000 \mathrm{a} 1$ \\
\hline 69 & $0.105000 \mathrm{a} 1$ \\
\hline 28 & $0.105000 \mathrm{a} 1$ \\
\hline 31 & $0.105000 \mathrm{a} 1$ \\
\hline 101 & $0.105000 \mathrm{a} 1$ \\
\hline 147 & $0.105000 \mathrm{a} 1$ \\
\hline 148 & $0.105000 \mathrm{a} 1$ \\
\hline 176 & $0.105000 \mathrm{a} 1$ \\
\hline 191 & $0.105000 \mathrm{a} 1$ \\
\hline 88 & $0.105000 \mathrm{a} 1$ \\
\hline 103 & $0.106667 \mathrm{a} 1$ \\
\hline 89 & $0.106667 \mathrm{a} 1$ \\
\hline 168 & $0.106667 \mathrm{a} 1$ \\
\hline 95 & $0.106667 \mathrm{a} 1$ \\
\hline 223 & $0.125000 \mathrm{a} 1$ \\
\hline 218 & $0.125000 \mathrm{a} 1$ \\
\hline 206 & $0.125000 \mathrm{a} 1$ \\
\hline 96 & $0.126667 \mathrm{a} 1$ \\
\hline 106 & $0.126667 \mathrm{a} 1$ \\
\hline 64 & $0.126667 \mathrm{a} 1$ \\
\hline 66 & $0.126667 \mathrm{a} 1$ \\
\hline 128 & $0.126667 \mathrm{a} 1$ \\
\hline 45 & $0.126667 \mathrm{a} 1$ \\
\hline 56 & $0.126667 \mathrm{a} 1$ \\
\hline 121 & $0.126667 \mathrm{a} 1$ \\
\hline 217 & $0.126667 \mathrm{a} 1$ \\
\hline 113 & $0.126667 \mathrm{a} 1$ \\
\hline 26 & $0.128333 \mathrm{a} 1$ \\
\hline 186 & $0.146667 \mathrm{a} 1$ \\
\hline 161 & $0.146667 \mathrm{a} 1$ \\
\hline 151 & $0.146667 \mathrm{a} 1$ \\
\hline 107 & $0.146667 \mathrm{a} 1$ \\
\hline 108 & $0.146667 \mathrm{a} 1$ \\
\hline 114 & $0.146667 \mathrm{a} 1$ \\
\hline 126 & $0.146667 \mathrm{a} 1$ \\
\hline 105 & $0.146667 \mathrm{a} 1$ \\
\hline 37 & $0.146667 \mathrm{a} 1$ \\
\hline 225 & $0.146667 \mathrm{a} 1$ \\
\hline 19 & $0.146667 \mathrm{a} 1$ \\
\hline 141 & $0.148333 \mathrm{a} 1$ \\
\hline
\end{tabular}




\begin{tabular}{|c|c|}
\hline 169 & $0.148333 \mathrm{a} 1$ \\
\hline 162 & $0.148333 \mathrm{a} 1$ \\
\hline 70 & $0.166667 \mathrm{a} 1$ \\
\hline 195 & $0.166667 \mathrm{a} 1$ \\
\hline 173 & $0.166667 \mathrm{a} 1$ \\
\hline 3 & $0.166667 \mathrm{a} 1$ \\
\hline 154 & $0.166667 \mathrm{a} 1$ \\
\hline 209 & $0.166667 \mathrm{a} 1$ \\
\hline 207 & $0.166667 \mathrm{a} 1$ \\
\hline 63 & $0.168333 \mathrm{a} 1$ \\
\hline 214 & $0.168333 \mathrm{a} 1$ \\
\hline 79 & $0.168333 \mathrm{a} 1$ \\
\hline 117 & $0.168333 \mathrm{a} 1$ \\
\hline 75 & $0.170000 \mathrm{a} 1$ \\
\hline 58 & $0.170000 \mathrm{a} 1$ \\
\hline 44 & $0.170000 \mathrm{a} 1$ \\
\hline 65 & $0.188333 \mathrm{a} 1$ \\
\hline 16 & $0.188333 \mathrm{a} 1$ \\
\hline 10 & $0.188333 \mathrm{a} 1$ \\
\hline 104 & $0.188333 \mathrm{a} 1$ \\
\hline 208 & $0.190000 \mathrm{a} 1$ \\
\hline 7 & $0.190000 \mathrm{a} 1$ \\
\hline 47 & $0.208333 \mathrm{a} 1$ \\
\hline 41 & $0.208333 \mathrm{a} 1$ \\
\hline 50 & $0.208333 \mathrm{a} 1$ \\
\hline 14 & $0.210000 \mathrm{a} 1$ \\
\hline 187 & $0.210000 \mathrm{a} 1$ \\
\hline 222 & $0.210000 \mathrm{a} 1$ \\
\hline 158 & $0.210000 \mathrm{a} 1$ \\
\hline 139 & $0.210000 \mathrm{a} 1$ \\
\hline 84 & $0.210000 \mathrm{a} 1$ \\
\hline 219 & $0.210000 \mathrm{a} 1$ \\
\hline 67 & $0.210000 \mathrm{a} 1$ \\
\hline 43 & $0.211667 \mathrm{a} 1$ \\
\hline 54 & $0.230000 \mathrm{a} 1$ \\
\hline 48 & $0.230000 \mathrm{a} 1$ \\
\hline 97 & $0.230000 \mathrm{a} 1$ \\
\hline 120 & $0.230000 \mathrm{a} 1$ \\
\hline 99 & $0.231667 \mathrm{a} 1$ \\
\hline 27 & $0.231667 \mathrm{a} 1$ \\
\hline 12 & $0.231667 \mathrm{a} 1$ \\
\hline 9 & $0.231667 \mathrm{a} 1$ \\
\hline 188 & $0.231667 \mathrm{a} 1$ \\
\hline 184 & $0.250000 \mathrm{a} 1$ \\
\hline 55 & $0.250000 \mathrm{a} 1$ \\
\hline 175 & $0.250000 \mathrm{a} 1$ \\
\hline 46 & $0.251667 \mathrm{a} 1$ \\
\hline 190 & $0.251667 \mathrm{a} 1$ \\
\hline 215 & $0.251667 \mathrm{a} 1$ \\
\hline 13 & $0.251667 \mathrm{a} 1$ \\
\hline 204 & $0.251667 \mathrm{a} 1$ \\
\hline 4 & $0.251667 \mathrm{a} 1$ \\
\hline 33 & $0.251667 \mathrm{a} 1$ \\
\hline 20 & $0.251667 \mathrm{a} 1$ \\
\hline 90 & $0.251667 \mathrm{a} 1$ \\
\hline 143 & $0.251667 \mathrm{a} 1$ \\
\hline 61 & $0.251667 \mathrm{a} 1$ \\
\hline 74 & $0.253333 \mathrm{a} 1$ \\
\hline 144 & $0.253333 \mathrm{a} 1$ \\
\hline 83 & $0.271667 \mathrm{a} 1$ \\
\hline 102 & $0.271667 \mathrm{a} 1$ \\
\hline 193 & $0.271667 \mathrm{a} 1$ \\
\hline 199 & $0.273333 \mathrm{a} 1$ \\
\hline 111 & $0.273333 \mathrm{a} 1$ \\
\hline 18 & $0.273333 \mathrm{a} 1$ \\
\hline 167 & $0.291667 \mathrm{a} 1$ \\
\hline 138 & $0.293333 \mathrm{a} 1$ \\
\hline 213 & $0.293333 \mathrm{a} 1$ \\
\hline 22 & $0.293333 \mathrm{a} 1$ \\
\hline 71 & $0.293333 \mathrm{a} 1$ \\
\hline 109 & $0.293333 \mathrm{a} 1$ \\
\hline 21 & $0.313333 \mathrm{a} 1$ \\
\hline 81 & $0.313333 \mathrm{a} 1$ \\
\hline 116 & $0.315000 \mathrm{a} 1$ \\
\hline
\end{tabular}




\begin{tabular}{|c|c|}
\hline 226 & $0.315000 \mathrm{a} 1$ \\
\hline 25 & $0.335000 \mathrm{a} 1$ \\
\hline 227 & $0.335000 \mathrm{a} 1$ \\
\hline 38 & $0.335000 \mathrm{a} 1$ \\
\hline 156 & $0.335000 \mathrm{a} 1$ \\
\hline 155 & $0.335000 \mathrm{a} 1$ \\
\hline 91 & $0.335000 \mathrm{a} 1$ \\
\hline 34 & $0.336667 \mathrm{a} 1$ \\
\hline 62 & $0.336667 \mathrm{a} 1$ \\
\hline 127 & $0.355000 \mathrm{a} 1$ \\
\hline 29 & $0.355000 \mathrm{a} 1$ \\
\hline 115 & 0.355000 a 1 \\
\hline 238 & $0.355000 \mathrm{a} 1$ \\
\hline 72 & $0.356667 \mathrm{a} 1$ \\
\hline 87 & $0.376667 \mathrm{a} 1$ \\
\hline 230 & $0.376667 \mathrm{a} 1$ \\
\hline 163 & $0.376667 \mathrm{a} 1$ \\
\hline 118 & $0.376667 \mathrm{a} 1$ \\
\hline 200 & $0.396667 \mathrm{a} 1$ \\
\hline 78 & $0.396667 \mathrm{a} 1$ \\
\hline 30 & $0.398333 \mathrm{a} 1$ \\
\hline 164 & $0.398333 \mathrm{a} 1$ \\
\hline 229 & $0.416667 \mathrm{a} 1$ \\
\hline 142 & 0.418333 a 1 \\
\hline 198 & $0.438333 \mathrm{a} 1$ \\
\hline 134 & $0.440000 \mathrm{a} 1$ \\
\hline 52 & $0.440000 \mathrm{a} 1$ \\
\hline 23 & $0.440000 \mathrm{a} 1$ \\
\hline 2 & $0.460000 \mathrm{a} 2$ \\
\hline 32 & $0.460000 \mathrm{a} 2$ \\
\hline 86 & $0.460000 \mathrm{a} 2$ \\
\hline 231 & $0.480000 \mathrm{a} 2$ \\
\hline 77 & $0.480000 \mathrm{a} 2$ \\
\hline 160 & $0.480000 \mathrm{a} 2$ \\
\hline 174 & $0.481667 \mathrm{a} 2$ \\
\hline 228 & $0.481667 \mathrm{a} 2$ \\
\hline 112 & $0.501667 \mathrm{a} 2$ \\
\hline 136 & $0.501667 \mathrm{a} 2$ \\
\hline 6 & $0.501667 \mathrm{a} 2$ \\
\hline 202 & $0.503333 \mathrm{a} 2$ \\
\hline 232 & $0.521667 \mathrm{a} 2$ \\
\hline 171 & $0.523333 \mathrm{a} 2$ \\
\hline 8 & $0.543333 \mathrm{a} 2$ \\
\hline 189 & $0.543333 \mathrm{a} 2$ \\
\hline 51 & $0.563333 \mathrm{a} 2$ \\
\hline 235 & $0.563333 \mathrm{a} 2$ \\
\hline 234 & $0.565000 \mathrm{a} 2$ \\
\hline 119 & $0.585000 \mathrm{a} 2$ \\
\hline 197 & $0.605000 \mathrm{a} 2$ \\
\hline 211 & $0.626667 \mathrm{a} 2$ \\
\hline 80 & $0.628333 \mathrm{a} 2$ \\
\hline 165 & $0.628333 \mathrm{a} 2$ \\
\hline 17 & $0.648333 \mathrm{a} 2$ \\
\hline 57 & $0.668333 \mathrm{a} 2$ \\
\hline 181 & $0.690000 \mathrm{a} 2$ \\
\hline 205 & $0.731667 \mathrm{a} 2$ \\
\hline 178 & $0.751667 \mathrm{a} 2$ \\
\hline 15 & $0.813333 \mathrm{a} 3$ \\
\hline 42 & $0.835000 \mathrm{a} 3$ \\
\hline 82 & $0.835000 \mathrm{a} 3$ \\
\hline 201 & $0.896667 \mathrm{a} 3$ \\
\hline 152 & $0.896667 \mathrm{a} 3$ \\
\hline 5 & $0.918333 \mathrm{a} 3$ \\
\hline 233 & 0.918333 a3 \\
\hline 221 & $0.960000 \mathrm{a} 3$ \\
\hline 11 & $1.021667 \mathrm{a} 3$ \\
\hline 24 & $1.023333 \mathrm{a} 3$ \\
\hline 76 & $1.023333 \mathrm{a} 3$ \\
\hline 237 & $1.396667 \mathrm{a} 4$ \\
\hline 236 & $1.460000 \mathrm{a} 4$ \\
\hline 68 & $1.668333 \mathrm{a} 4$ \\
\hline
\end{tabular}


Variável analisada: SEV

Opção de transformação: Raiz quadrada de $\mathrm{Y}+1.0$-SQRT $(\mathrm{Y}+1.0)$

TABELA DE ANÁLISE DE VARIÂNCIA

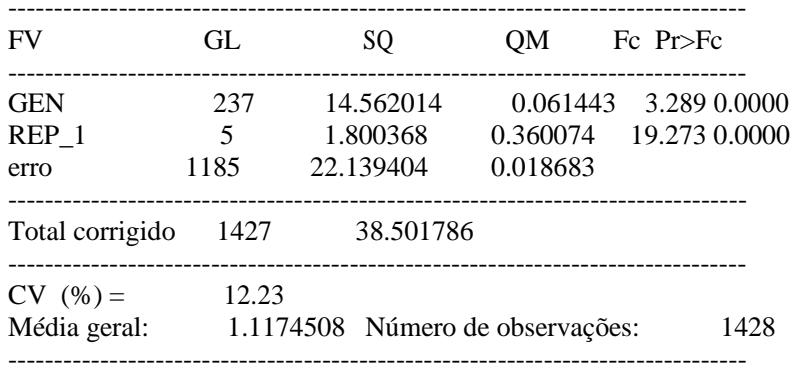

Teste Scott-Knott (1974) para a FV GEN

NMS: 0,05

Média harmonica do número de repetições (r): 6 Erro padrão: 0,0558017943618404

\begin{tabular}{lc} 
Tratamentos & Médias Resultados do teste \\
\hline 140 & $1.000000 \mathrm{a} 1$ \\
135 & $1.000000 \mathrm{a} 1$ \\
146 & $1.000000 \mathrm{a} 1$ \\
180 & $1.000000 \mathrm{a} 1$ \\
220 & $1.000000 \mathrm{a} 1$ \\
122 & $1.000000 \mathrm{a} 1$ \\
100 & $1.000000 \mathrm{a} 1$ \\
123 & $1.000000 \mathrm{a} 1$ \\
133 & $1.000000 \mathrm{a} 1$ \\
129 & $1.000000 \mathrm{a} 1$ \\
216 & $1.000000 \mathrm{a} 1$ \\
39 & $1.010502 \mathrm{a} 1$ \\
36 & $1.010502 \mathrm{a} 1$ \\
196 & $1.010502 \mathrm{a} 1$ \\
59 & $1.010502 \mathrm{a} 1$ \\
137 & $1.010502 \mathrm{a} 1$ \\
145 & $1.010502 \mathrm{a} 1$ \\
40 & $1.019672 \mathrm{a} 1$ \\
192 & $1.019672 \mathrm{a} 1$ \\
53 & $1.019672 \mathrm{a} 1$ \\
150 & $1.019672 \mathrm{a} 1$ \\
159 & $1.019672 \mathrm{a} 1$ \\
60 & $1.019672 \mathrm{a} 1$ \\
93 & $1.019672 \mathrm{a} 1$ \\
157 & $1.019672 \mathrm{a} 1$ \\
94 & $1.019672 \mathrm{a} 1$ \\
73 & $1.021005 \mathrm{a} 1$ \\
185 & $1.021005 \mathrm{a} 1$ \\
132 & $1.021005 \mathrm{a} 1$ \\
149 & $1.029122 \mathrm{a} 1$ \\
203 & $1.029122 \mathrm{a} 1$ \\
& $1.029122 \mathrm{a} 1$ \\
179 & $1.030175 \mathrm{a} 1$ \\
&
\end{tabular}




\begin{tabular}{|c|c|}
\hline 177 & $1.030175 \mathrm{a} 1$ \\
\hline 110 & $1.030175 \mathrm{a} 1$ \\
\hline 1 & $1.037457 \mathrm{a} 1$ \\
\hline 98 & $1.037457 \mathrm{a} 1$ \\
\hline 182 & $1.037457 \mathrm{a} 1$ \\
\hline 125 & $1.039345 \mathrm{a} 1$ \\
\hline 212 & $1.039345 \mathrm{a} 1$ \\
\hline 92 & $1.039345 \mathrm{a} 1$ \\
\hline 35 & $1.039625 \mathrm{a} 1$ \\
\hline 183 & $1.039625 \mathrm{a} 1$ \\
\hline 130 & $1.039625 \mathrm{a} 1$ \\
\hline 49 & $1.039625 \mathrm{a} 1$ \\
\hline 172 & $1.039625 \mathrm{a} 1$ \\
\hline 194 & $1.040677 \mathrm{a} 1$ \\
\hline 131 & $1.040677 \mathrm{a} 1$ \\
\hline 166 & $1.040677 \mathrm{a} 1$ \\
\hline 124 & $1.040677 \mathrm{a} 1$ \\
\hline 153 & $1.046119 \mathrm{a} 1$ \\
\hline 101 & $1.046119 \mathrm{a} 1$ \\
\hline 170 & $1.047960 \mathrm{a} 1$ \\
\hline 147 & $1.047960 \mathrm{a} 1$ \\
\hline 28 & $1.047960 \mathrm{a} 1$ \\
\hline 148 & $1.047960 \mathrm{a} 1$ \\
\hline 31 & $1.048795 \mathrm{a} 1$ \\
\hline 88 & $1.048795 \mathrm{a} 1$ \\
\hline 191 & $1.048795 \mathrm{a} 1$ \\
\hline 69 & $1.048795 \mathrm{a} 1$ \\
\hline 176 & $1.049847 \mathrm{a} 1$ \\
\hline 85 & $1.049847 \mathrm{a} 1$ \\
\hline 103 & $1.050127 \mathrm{a} 1$ \\
\hline 89 & $1.050127 \mathrm{a} 1$ \\
\hline 95 & $1.050127 \mathrm{a} 1$ \\
\hline 168 & $1.051180 \mathrm{a} 1$ \\
\hline 66 & $1.056622 \mathrm{a} 1$ \\
\hline 218 & $1.057130 \mathrm{a} 1$ \\
\hline 206 & $1.057130 \mathrm{a} 1$ \\
\hline 223 & $1.057130 \mathrm{a} 1$ \\
\hline 106 & $1.058462 \mathrm{a} 1$ \\
\hline 96 & $1.058462 \mathrm{a} 1$ \\
\hline 128 & $1.058462 \mathrm{a} 1$ \\
\hline 64 & $1.058462 \mathrm{a} 1$ \\
\hline 45 & $1.058462 \mathrm{a} 1$ \\
\hline 56 & $1.058462 \mathrm{a} 1$ \\
\hline 113 & $1.059297 \mathrm{a} 1$ \\
\hline 121 & $1.059297 \mathrm{a} 1$ \\
\hline 217 & $1.060350 \mathrm{a} 1$ \\
\hline 26 & $1.060630 \mathrm{a} 1$ \\
\hline 19 & $1.061855 \mathrm{a} 1$ \\
\hline 37 & $1.061855 \mathrm{a} 1$ \\
\hline 151 & $1.064315 \mathrm{a} 1$ \\
\hline 105 & $1.064315 \mathrm{a} 1$ \\
\hline 126 & $1.065791 \mathrm{a} 1$ \\
\hline 108 & $1.066580 \mathrm{a} 1$ \\
\hline 186 & $1.066580 \mathrm{a} 1$ \\
\hline 169 & $1.067124 \mathrm{a} 1$ \\
\hline 141 & $1.067124 \mathrm{a} 1$ \\
\hline 107 & $1.067632 \mathrm{a} 1$ \\
\hline 114 & $1.067632 \mathrm{a} 1$ \\
\hline 161 & $1.068467 \mathrm{a} 1$ \\
\hline 162 & $1.068747 \mathrm{a} 1$ \\
\hline 225 & $1.069519 \mathrm{a} 1$ \\
\hline 79 & $1.072358 \mathrm{a} 1$ \\
\hline 173 & $1.073485 \mathrm{a} 1$ \\
\hline 207 & $1.074915 \mathrm{a} 1$ \\
\hline 209 & $1.074915 \mathrm{a} 1$ \\
\hline 3 & $1.074915 \mathrm{a} 1$ \\
\hline 70 & $1.076802 \mathrm{a} 1$ \\
\hline 154 & $1.076802 \mathrm{a} 1$ \\
\hline 195 & $1.076802 \mathrm{a} 1$ \\
\hline 214 & $1.077082 \mathrm{a} 1$ \\
\hline 63 & $1.077082 \mathrm{a} 1$ \\
\hline 117 & $1.077917 \mathrm{a} 1$ \\
\hline 44 & $1.079250 \mathrm{a} 1$ \\
\hline 75 & $1.079250 \mathrm{a} 1$ \\
\hline
\end{tabular}




\begin{tabular}{|c|c|}
\hline 16 & $1.079538 \mathrm{a} 1$ \\
\hline 58 & $1.080302 \mathrm{a} 1$ \\
\hline 10 & $1.081527 \mathrm{a} 1$ \\
\hline 47 & $1.083333 \mathrm{a} 1$ \\
\hline 104 & $1.086252 \mathrm{a} 1$ \\
\hline 7 & $1.087585 \mathrm{a} 1$ \\
\hline 65 & $1.088139 \mathrm{a} 1$ \\
\hline 208 & $1.088419 \mathrm{a} 1$ \\
\hline 41 & $1.088708 \mathrm{a} 1$ \\
\hline 67 & $1.090040 \mathrm{a} 1$ \\
\hline 14 & $1.092030 \mathrm{a} 1$ \\
\hline 222 & $1.092238 \mathrm{a} 1$ \\
\hline 50 & $1.093157 \mathrm{a} 1$ \\
\hline 84 & $1.094079 \mathrm{a} 1$ \\
\hline 158 & $1.094914 \mathrm{a} 1$ \\
\hline 139 & $1.094914 \mathrm{a} 1$ \\
\hline 219 & $1.095966 \mathrm{a} 1$ \\
\hline 187 & $1.097807 \mathrm{a} 1$ \\
\hline 43 & $1.098087 \mathrm{a} 1$ \\
\hline 97 & $1.101773 \mathrm{a} 1$ \\
\hline 54 & $1.102607 \mathrm{a} 1$ \\
\hline 55 & $1.103006 \mathrm{a} 1$ \\
\hline 12 & $1.103940 \mathrm{a} 1$ \\
\hline 9 & $1.105416 \mathrm{a} 1$ \\
\hline 48 & $1.105924 \mathrm{a} 1$ \\
\hline 99 & $1.106205 \mathrm{a} 1$ \\
\hline 46 & $1.106750 \mathrm{a} 1$ \\
\hline 120 & $1.106977 \mathrm{a} 1$ \\
\hline 188 & $1.107039 \mathrm{a} 1$ \\
\hline 27 & $1.109144 \mathrm{a} 1$ \\
\hline 20 & $1.109815 \mathrm{a} 1$ \\
\hline 13 & $1.109815 \mathrm{a} 1$ \\
\hline 4 & $1.110434 \mathrm{a} 1$ \\
\hline 33 & $1.110650 \mathrm{a} 1$ \\
\hline 215 & $1.111702 \mathrm{a} 1$ \\
\hline 190 & $1.112057 \mathrm{a} 1$ \\
\hline 204 & $1.112275 \mathrm{a} 1$ \\
\hline 184 & $1.112372 \mathrm{a} 1$ \\
\hline 90 & $1.112699 \mathrm{a} 1$ \\
\hline 61 & $1.112699 \mathrm{a} 1$ \\
\hline 143 & $1.113751 \mathrm{a} 1$ \\
\hline 175 & $1.114260 \mathrm{a} 1$ \\
\hline 74 & $1.114866 \mathrm{a} 1$ \\
\hline 144 & $1.116707 \mathrm{a} 1$ \\
\hline 83 & $1.116996 \mathrm{a} 1$ \\
\hline 18 & $1.118477 \mathrm{a} 1$ \\
\hline 102 & $1.118985 \mathrm{a} 1$ \\
\hline 167 & $1.120791 \mathrm{a} 1$ \\
\hline 199 & $1.122560 \mathrm{a} 1$ \\
\hline 193 & $1.122921 \mathrm{a} 1$ \\
\hline 111 & $1.123612 \mathrm{a} 1$ \\
\hline 138 & $1.126422 \mathrm{a} 1$ \\
\hline 22 & $1.127647 \mathrm{a} 1$ \\
\hline 213 & $1.129054 \mathrm{a} 1$ \\
\hline 109 & $1.131536 \mathrm{a} 1$ \\
\hline 71 & $1.131947 \mathrm{a} 1$ \\
\hline 21 & $1.135615 \mathrm{a} 1$ \\
\hline 226 & $1.138357 \mathrm{a} 1$ \\
\hline 116 & $1.139556 \mathrm{a} 1$ \\
\hline 81 & $1.141117 \mathrm{a} 1$ \\
\hline 25 & $1.144208 \mathrm{a} 1$ \\
\hline 238 & $1.145188 \mathrm{a} 1$ \\
\hline 91 & $1.145843 \mathrm{a} 1$ \\
\hline 156 & $1.146051 \mathrm{a} 1$ \\
\hline 34 & $1.146375 \mathrm{a} 1$ \\
\hline 227 & $1.148005 \mathrm{a} 1$ \\
\hline 38 & $1.150567 \mathrm{a} 1$ \\
\hline 127 & $1.151490 \mathrm{a} 1$ \\
\hline 62 & $1.151535 \mathrm{a} 1$ \\
\hline 155 & $1.151997 \mathrm{a} 1$ \\
\hline 72 & $1.156769 \mathrm{a} 1$ \\
\hline 29 & $1.157472 \mathrm{a} 1$ \\
\hline 87 & $1.158103 \mathrm{a} 1$ \\
\hline 115 & $1.159737 \mathrm{a} 1$ \\
\hline
\end{tabular}




\begin{tabular}{|c|c|}
\hline 230 & $1.161274 \mathrm{a} 1$ \\
\hline 163 & $1.161787 \mathrm{a} 1$ \\
\hline 118 & $1.167564 \mathrm{a} 1$ \\
\hline 200 & $1.168967 \mathrm{a} 1$ \\
\hline 78 & $1.171940 \mathrm{a} 1$ \\
\hline 30 & $1.172289 \mathrm{a} 1$ \\
\hline 229 & $1.173659 \mathrm{a} 1$ \\
\hline 164 & $1.175240 \mathrm{a} 1$ \\
\hline 134 & $1.180703 \mathrm{a} 2$ \\
\hline 142 & $1.183622 \mathrm{a} 2$ \\
\hline 198 & $1.190480 \mathrm{a} 2$ \\
\hline 32 & $1.191994 \mathrm{a} 2$ \\
\hline 52 & $1.194226 \mathrm{a} 2$ \\
\hline 160 & $1.196788 \mathrm{a} 2$ \\
\hline 23 & $1.197328 \mathrm{a} 2$ \\
\hline 231 & $1.198488 \mathrm{a} 2$ \\
\hline 86 & $1.199244 \mathrm{a} 2$ \\
\hline 2 & $1.199497 \mathrm{a} 2$ \\
\hline 77 & $1.200894 \mathrm{a} 2$ \\
\hline 136 & $1.208914 \mathrm{a} 2$ \\
\hline 174 & $1.208947 \mathrm{a} 2$ \\
\hline 228 & $1.209105 \mathrm{a} 2$ \\
\hline 202 & $1.211815 \mathrm{a} 2$ \\
\hline 6 & $1.213313 \mathrm{a} 2$ \\
\hline 232 & $1.218673 \mathrm{a} 2$ \\
\hline 112 & $1.219705 \mathrm{a} 2$ \\
\hline 171 & $1.220430 \mathrm{a} 2$ \\
\hline 51 & $1.226309 \mathrm{a} 2$ \\
\hline 8 & $1.226488 \mathrm{a} 2$ \\
\hline 234 & $1.228195 \mathrm{a} 2$ \\
\hline 189 & $1.231161 \mathrm{a} 2$ \\
\hline 235 & $1.241833 \mathrm{a} 2$ \\
\hline 119 & $1.249876 \mathrm{a} 2$ \\
\hline 197 & $1.251179 \mathrm{a} 2$ \\
\hline 80 & $1.258114 \mathrm{a} 2$ \\
\hline 165 & $1.261389 \mathrm{a} 2$ \\
\hline 211 & $1.262739 \mathrm{a} 2$ \\
\hline 17 & $1.265551 \mathrm{a} 2$ \\
\hline 181 & $1.278090 \mathrm{a} 2$ \\
\hline 57 & $1.285253 \mathrm{a} 2$ \\
\hline 205 & $1.285698 \mathrm{a} 2$ \\
\hline 178 & $1.310472 \mathrm{a} 2$ \\
\hline 15 & $1.329053 \mathrm{a} 3$ \\
\hline 82 & $1.333007 \mathrm{a} 3$ \\
\hline 42 & $1.347040 \mathrm{a} 3$ \\
\hline 233 & $1.348043 \mathrm{a} 3$ \\
\hline 5 & $1.348211 \mathrm{a} 3$ \\
\hline 201 & $1.352570 \mathrm{a} 3$ \\
\hline 152 & $1.354467 \mathrm{a} 3$ \\
\hline 221 & $1.375051 \mathrm{a} 3$ \\
\hline 76 & $1.379854 \mathrm{a} 3$ \\
\hline 11 & $1.408359 \mathrm{a} 3$ \\
\hline 24 & $1.419130 \mathrm{a} 3$ \\
\hline 237 & $1.515343 \mathrm{a} 4$ \\
\hline 236 & $1.555222 \mathrm{a} 4$ \\
\hline 68 & $1.609482 \mathrm{a} 4$ \\
\hline
\end{tabular}

Estimativa de parâmetros genéticos para resistênciaàs doenças ferrugem e cercosporiose do cafeeiro

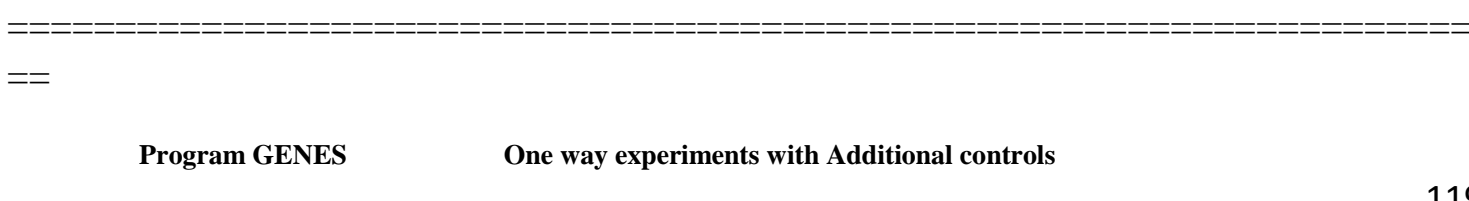




\begin{tabular}{|c|c|}
\hline Data file & C:Imateuslferrug cerc 6 epocas.txt \\
\hline Number of variables & 2 \\
\hline Number of Genotypes & 238 \\
\hline Number of Controls & $\mathbf{0}$ \\
\hline Date & 06-04-2016 \\
\hline
\end{tabular}

Analysis of variance of variable $=>x$ cercospora

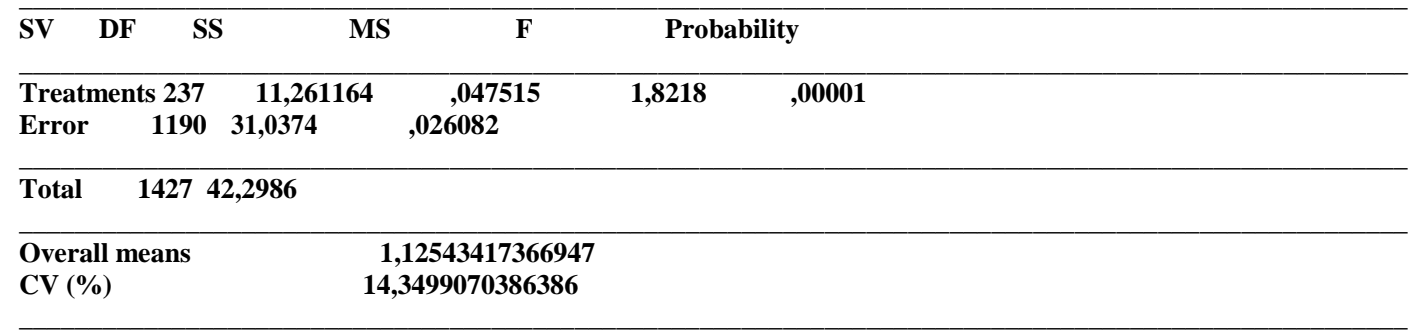

Genetic and environmental parameters- Obtained for genotypes

\begin{tabular}{lc}
\hline Phenotypic variance (means) &, 007919 \\
Environmental variance (means) &, 004347 \\
Genotypic variance (means) &, 003572 \\
Herdability (US: family means ) - \% & $\mathbf{4 5 , 1 0 8 7}$ \\
Correlation intraclass (US: plot)- \% & $\mathbf{1 2 , 0 4 6 5}$ \\
Coefficient of genetic variation (\%) & $\mathbf{5 , 3 1 0 7}$ \\
Relation CVg/CVe - Genotypes means &, 3701 \\
means number of replications & $\mathbf{6 ,}$ \\
\hline
\end{tabular}

Analysis of variance of variable $=>\mathbf{x}$ ferrugem

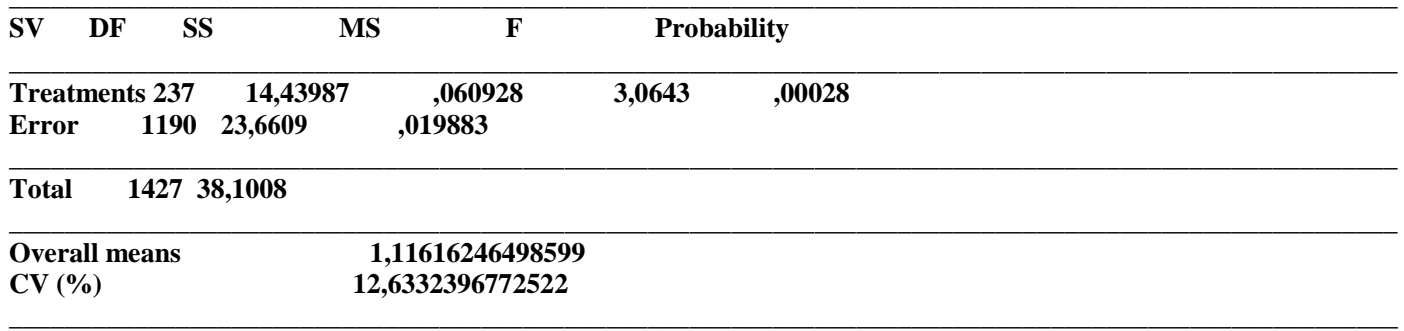

Genetic and environmental parameters- Obtained for genotypes

\begin{tabular}{lc}
\hline Phenotypic variance (means) &, 010155 \\
Environmental variance (means) &, 003314 \\
Genotypic variance (means) &, 006841 \\
Herdability (US: family means ) $-\%$ & $\mathbf{6 7 , 3 6 6 1}$ \\
Correlation intraclass (US: plot) $\%$ & $\mathbf{2 5 , 5 9 8}$ \\
Coefficient of genetic variation (\%) & $\mathbf{7 , 4 1 0 1}$ \\
Relation CVg/CVe - Genotypes means &, $\mathbf{5 8 6 6}$
\end{tabular}

means number of replications 6 ,

Phenotypic covariances

\begin{tabular}{|c|c|}
\hline \multicolumn{2}{|l|}{,007919,004443, 004443, 010155, } \\
\hline \multicolumn{2}{|r|}{ Genotypic covariances } \\
\hline \multicolumn{2}{|l|}{,003577, 0004063,004063, 0068441 } \\
\hline & Residual covariances \\
\hline \multicolumn{2}{|l|}{$\overline{0,026882,002278,002278,019883}$} \\
\hline & Phenotypics correlations \\
\hline
\end{tabular}

$\overline{1,4955,4955}$ 
Genotypic correlations

$\overline{1,, 822,822}$

1 ,

Residual correlations

$1,, 1,1$

\begin{tabular}{ll}
\hline & Means of the variables \\
\hline Gen Nobs $\quad$ means \\
\hline
\end{tabular}

$16 \begin{array}{lll}1,1067 & 1,0367\end{array}$

$\begin{array}{llll}1 & 6 & 1,1517 & 1,1983\end{array}$

$\begin{array}{lllll}3 & 6 & 1,1017 & 1,0733\end{array}$

$\begin{array}{lllll}4 & 6 & 1,0200 & 1,1083\end{array}$

$\begin{array}{lllll}5 & 6 & 1,1533 & 1,3467\end{array}$

$6 \quad 6 \quad 1,23331,2100$

$\begin{array}{llll}7 & 6 & 1,1033 & 1,0850\end{array}$

$86 \quad 1,25001,2250$

$96 \quad 1,14331,1033$

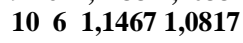

$\begin{array}{lllll}11 & 6 & 1,4067 & 1,4067\end{array}$

$126 \quad 1,11831,1017$

$\begin{array}{lllll}13 & 6 & 1,0300 & 1,1083\end{array}$

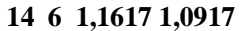

$\begin{array}{llll}15 & 6 & 1,2767 & 1,3283\end{array}$

$1661,15831,0783$

$\begin{array}{llll}17 & 6 & 1,3750 & 1,2633\end{array}$

$186 \quad 1,12171,1167$

$196 \quad 1,10001,0617$

$\begin{array}{llll}20 & 6 & 1,2050 & 1,1083\end{array}$

$\begin{array}{llll}21 & 6 & 1,3117 & 1,1333\end{array}$

$\begin{array}{lllll}22 & 6 & 1,1850 & 1,1267\end{array}$

$\begin{array}{llll}23 & 6 & 1,1833 & 1,1933\end{array}$

$246 \quad 1,15331,4183$

$\begin{array}{llll}25 & 6 & 1,1067 & 1,1433\end{array}$

$\begin{array}{llll}26 & 6 & 1,0950 & 1,0583\end{array}$

$\begin{array}{llll}27 & 6 & 1,1767 & 1,1083\end{array}$

$\begin{array}{llll}28 & 6 & 1,1400 & 1,0467\end{array}$

$\begin{array}{llll}29 & 6 & 1,2350 & 1,1567\end{array}$

$\begin{array}{llll}30 & 6 & 1,2350 & 1,1700\end{array}$

$\begin{array}{llll}31 & 6 & 1,0650 & 1,0483\end{array}$

$326 \quad 1,20331,1900$

$336 \quad 1,19331,1100$

$346 \quad 1,07501,1450$

$\begin{array}{llll}35 & 6 & 1,2100 & 1,0383\end{array}$

$366 \quad 1,19171,0100$

$\begin{array}{lllll}37 & 6 & 1,0650 & 1,0617\end{array}$

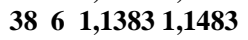

$\begin{array}{llll}39 & 6 & 1,0000 & 1,0100\end{array}$

$\begin{array}{llll}40 & 6 & 1,0000 & 1,0200\end{array}$

$416 \quad 1,04831,0883$

$\begin{array}{llll}42 & 6 & 1,2967 & 1,3433\end{array}$

$4361,20171,0950$

$\begin{array}{llll}44 & 6 & 1,1850 & 1,0767\end{array}$

$\begin{array}{lllll}45 & 6 & 1,1550 & 1,0567\end{array}$

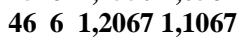

$\begin{array}{llll}47 & 6 & 1,1200 & 1,0833\end{array}$

$\begin{array}{llll}48 & 6 & 1,1350 & 1,1050\end{array}$

$\begin{array}{llll}49 & 6 & 1,0100 & 1,0383\end{array}$

$\begin{array}{llll}50 & 6 & 1,1950 & 1,0933\end{array}$

$\begin{array}{llll}51 & 6 & 1,3550 & 1,2250\end{array}$

$\begin{array}{llll}52 & 6 & 1,2717 & 1,1917\end{array}$

$\begin{array}{llll}53 & 6 & 1,0583 & 1,0200\end{array}$

$\begin{array}{llll}54 & 6 & 1,1567 & 1,1017\end{array}$

$\begin{array}{llll}55 & 6 & 1,1417 & 1,1033\end{array}$

$\begin{array}{llll}56 & 6 & 1,1433 & 1,0567\end{array}$

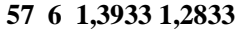

$\begin{array}{llll}58 & 6 & 1,1367 & 1,0783\end{array}$

$\begin{array}{lll}59 & 6 & 1,0767 \\ 1,0100\end{array}$ 
$606 \quad 1,17001,0200$

$6161,22671,1100$

$626 \quad 1,12671,1483$

$6361,03831,0750$

$\begin{array}{lll}646 & 1,2367 & 1,0567\end{array}$

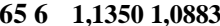

$6661,15671,0550$

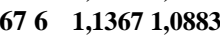

$686 \quad 1,31501,6083$

$6961,04831,0483$

$706 \quad 1,07831,0767$

$\begin{array}{ll}716 & 1,2917 \\ 1,1300\end{array}$

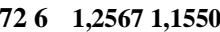

$7361,02001,0200$

$\begin{array}{lll}746 & 1,15331,1117\end{array}$

$\begin{array}{lll}75 & 6 & 1,2183 \\ 1,0767\end{array}$

$\begin{array}{llll}76 & 6 & 1,3050 & 1,3783\end{array}$

$776 \quad 1,26671,1983$

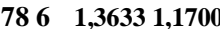

$\begin{array}{lll}796 & 1,1583 & 1,0717\end{array}$

$806 \quad 1,26331,2567$

$8161,17171,1400$

$8261,46671,3317$

$8361,28331,1150$

$8461,06831,0917$

$8561,19671,0500$

$866 \quad 1,22671,1967$

$876 \quad 1,22831,1583$

$8861,16331,0483$

$8961,06671,0483$

$906 \quad 1,23831,1100$

$9161,10171,1450$

$9261,06671,0400$

$9361,14171,0200$

$9461,03001,0200$

$9561,03671,0483$

$966 \quad 1,13831,0567$

$976 \quad 1,20501,1000$

$\begin{array}{lll}986 & 1,1983 & 1,0367\end{array}$

$9961,21001,1033$

$10061,11501,0000$

$10161,16001,0450$

$10261,09331,1183$

$10361,11331,0483$

$10461,14671,0850$

$10561,06831,0633$

$10661,05671,0567$

$10761,10171,0667$

$10861,14001,0650$

$10961,28831,1283$

$11061,10831,0300$

$11161,11001,1217$

$11261,18671,2167$

$11361,13331,0583$

$11461,21501,0667$

$1156 \quad 1,10501,1583$

$1166 \quad 1,20501,1367$

$11761,14671,0767$

$11861,11671,1650$

$1196 \quad 1,23171,2483$

$12061,09331,1067$

$12161,09501,0583$

$12261,02831,0000$

$12361,02001,0000$

$12461,05831,0400$

$12561,12171,0400$

$12661,09331,0650$

$12761,29501,1500$

$1286 \quad 1,07501,0567$

$12961,01001,0000$

$13061,13171,0383$

$13161,07331,0400$

$13261,13501,0283$

$13361,03001,0000$ 
$1346 \quad 1,05001,1783$

$13561,01001,0000$

$13661,07331,2067$

$13761,08831,0100$

$\begin{array}{lll}1386 & 1,2000 & 1,1267\end{array}$

$13961,15171,0933$

$14061,08831,0000$

$14161,11171,0650$

$14261,28831,1817$

$14361,15171,1117$

$14461,14171,1133$

$14561,01001,0100$

$14661,05831,0000$

$14761,02001,0467$

$14861,04831,0467$

$14961,04671,0283$

$15061,07671,0200$

$15161,07671,0633$

$15261,14501,3533$

$15361,04001,0450$

$15461,11331,0767$

$15561,10501,1483$

$15661,09671,1433$

$15761,04671,0200$

$1586 \quad 1,24001,0933$

$15961,04671,0200$

$16061,07501,1950$

$16161,02001,0683$

$16261,01001,0667$

$16361,10171,1600$

$16461,06001,1717$

$16561,15501,2600$

$16661,04671,0400$

$16761,18501,1200$

$16861,00001,0500$

$16961,03001,0650$

$17061,03001,0467$

$1716 \quad 1,10831,2183$

$17261,03831,0383$

$17361,27001,0733$

$1746 \quad 1,17001,2067$

$1756 \quad 1,09671,1133$

$17661,04831,0500$

$17761,02001,0300$

$17861,12171,3100$

$17961,04831,0300$

$18061,02001,0000$

$18161,10331,2767$

$\begin{array}{lll}1826 & 1,0967 & 1,0367\end{array}$

$18361,04001,0383$

$18461,06671,1100$

$18561,00001,0200$

$18661,10171,0650$

$1876 \quad 1,0767 \quad 1,0967$

$18861,07331,1050$

$18961,11831,2283$

$19061,07501,1100$

$19161,06671,0483$

$19261,03831,0200$

$19361,08331,1217$

$19461,06001,0400$

$1956 \quad 1,0567 \quad 1,0767$

$19661,03831,0100$

$19761,03831,2500$

$1986 \quad 1,03001,1883$

$19961,11001,1200$

$2006 \quad 1,04671,1667$

$20161,18331,3517$

$2026 \quad 1,33501,2083$

$20361,03001,0300$

$20461,04001,1100$

$20561,17331,2850$

$20661,17171,0567$

$20761,02831,0733$ 
$20861,02001,0867$

$20961,02831,0733$

$21061,02831,0200$

$21161,13501,2600$

$21261,03831,0400$

$21361,02001,1267$

$21461,04001,0750$

$21561,11831,1117$

$21661,07831,0000$

$21761,00001,0600$

$21861,09331,0567$

$21961,19671,0950$

$22061,02001,0000$

$22161,11501,3717$

$22261,02001,0900$

$22361,02001,0567$

$22461,00001,0283$

$22561,02831,0700$

$22661,09331,1350$

$22761,02001,1467$

$22861,2217 \quad 1,2067$

$22961,06331,1733$

$23061,16671,1583$

$23161,04671,1967$

$23261,16331,2183$

$23361,11001,3450$

$23461,05001,2267$

$23561,21671,2400$

$23661,13501,5517$

$23761,10171,5150$

$23861,08501,1450$

Note: In this procedure the file of means will include the column of the number of replications.

Variance within

Gen Nobs $\quad$ Variances

$16,0323,0081$

$26,0565,0251$

$36,0153,0129$

$46,0024,0217$

$56,0261,1211$

$6 \quad 6,0155,0347$

$\begin{array}{llll}7 & 6 & 0111,0082\end{array}$

$86,0446,0470$

$96,0260,0111$

$106,0451,0223$

$116,2034,0457$

$126,0191,0153$

$136,0025,0237$

$146,0313,0209$

$156,1182,0559$

$166,0425,0270$

$176,1049,0564$

$186,0387,0263$

$196,0189,0228$

$206,0288,0237$

$216,0315,0277$

$226,0348,0256$

$236,0398,0073$

$246,0564,0117$

$256,0323,0309$

$266,0102,0039$

$276,0339,0018$

$286,0161,0078$

$296,0697,0180$

$306,0435,0285$

$316,0104,0059$

$326,0569,0468$

$336,0397,0215$

$346,0094,0272$

$356,0385,0047$

$366,0417,0006$

$376,0124,0228$ 
$1126,0607,0167$

1136 ,0297,0053

$1146,0797,0079$

$1156,0100,0116$

$1166,0561,0191$

$1176,0451,0074$

$1186,0253,0157$

$1196,0815,0269$

$1206,0143,0054$

$1216,0082,0053$

$1226,0048,0000$

$1236,0010,0000$

$1246,0053,0024$

$1256,0123,0038$

$1266,0143,0124$

$1276,0588,0347$

$1286,0114,0073$

$1296,0006,0000$

$1306,0379,0047$

$1316,0155,0024$

$1326,0250,0048$

$1336,0025,0000$

$1346,0035,0549$

$1356,0006,0000$

$1366,0155,0481$

$1376,0036,0006$

$1386,0404,0295$

$1396,0299,0128$

$1406,0036,0000$

$1416,0129,0110$

$1426,0299,0201$

$1436,0329,0129$

$1446,0329,0073$

$1456,0006,0006$

$1466,0053,0000$

$1476,0024,0078$

$1486,0044,0078$

$1496,0078,0048$

$1506,0069,0024$

$1516,0084,0164$

$1526,0232,0742$

$1536,0024,0121$

$1546,0137,0084$

$1556,0066,0091$

1566 ,0061,0250

$1576,0078,0024$

$1586,0500,0128$

$1596,0078,0024$

$1606,0094,0567$

$1616,0024,0059$

$1626,0006,0069$

$1636,0137,0317$

$1646,0043,0202$

$1656,0208,0451$

$1666,0078,0024$

$1676,0062,0424$

$1686,0000,0020$

$1696,0025,0110$

$1706,0025,0078$

$1716,0253,0405$

$1726,0047,0047$

$1736,0070,0169$

1746 ,0285,0240

1756 ,0047,0097

$1766,0044,0035$

$1776,0024,0025$

$1786,0103,0409$

$1796,0059,0025$

$1806,0010,0000$

$1816,0111,0680$

$1826,0047,0081$

$1836,0024,0047$

$1846,0079,0145$

$1856,0000,0010$ 
$1866,0147,0104$

$1876,0069,0057$

$1886,0139,0070$

$1896,0171,0326$

$1906,0094,0175$

$1916,0069,0059$

$1926,0047,0024$

$1936,0117,0123$

$1946,0043,0024$

$1956,0087,0084$

$1966,0047,0006$

1976 ,0047,0475

$1986,0025,0248$

$1996,0215,0155$

$2006,0078,0353$

$2016,0411,0803$

$2026,0314,0412$

$2036,0025,0025$

$2046,0024,0171$

$2056,0212,0946$

$2066,0221,0087$

$2076,0048,0129$

$2086,0024,0061$

$2096,0048,0129$

$2106,0048,0024$

$2116,0249,0380$

$2126,0047,0038$

$2136,0024,0216$

$2146,0038,0094$

$2156,0191,0189$

$2166,0049,0000$

$2176,0000,0029$

$2186,0143,0087$

$2196,0537,0102$

$2206,0024,0000$

$2216,0329,0840$

$2226,0010,0194$

$2236,0024,0087$

$2246,0000,0048$

$2256,0048,0035$

$2266,0108,0219$

2276 ,0010,0201

$2286,0607,0236$

2296 ,0164,0467

$2306,0073,0327$

$2316,0078,0518$

$2326,0485,0435$

$2336,0155,1209$

$2346,0035,0681$

$2356,0428,0249$

$2366,0259,0494$

$2376,0207,1208$

$2386,0117,0521$

Note: In this procedure the file of variances will include the column on the number of replications.

UNIVERSIDADE FEDERAL DE VIÇOSA

36571-000 VIÇOSA - MG - BRASIL 